\title{
THE EUROPEAN EXPERIENCE WITH ATTORNEY FEE SHIFTING
}

\author{
Werner Pfennigstorf*
}

\section{INTRODUCTION}

A discussion of the American rule on the allocation of attorney fees would not be complete without consideration of potential alternatives. Fortunately, Americans do not have to rely on hypothetical models alone but have a whole world around them where they can study different systems of cost and fee allocation in actual operation. Indeed, one of the aspects that make the American rule such a worthwhile subject of study is that on an international level it represents the exception rather than the rule.

Americans, of course, have been aware of the fact that different rules prevail in other countries, especially that in England "the costs follow the event." So far, however, with the exception of England, ${ }^{2}$ there has been no thorough analysis and evaluation of those foreign rules and their application. ${ }^{3}$ This article is intended to fill the gap at least partially. Since it was conceived, designed, researched, and written as part of a multidimensional, multidisciplinary symposium devoted to the American rule, it was written primarily for an American audience. Thus, it presupposes familiarity with the American rule and complete lack of familiarity with any of the European systems. In addition, the objectives of the symposium are reflected in the scope and the limits of this report. Specifically, since the American

\footnotetext{
Copyright (C) 1984 by Law and Contemporary Problems

* Research Attorney, American Bar Foundation, Dr. jur. habil., University of Hamburg, 1960/1974, M.C.L., University of Michigan, 1961 .

1. These words are used in the pertinent English court rules, see infra note 54. The term "costs" in these rules and in this article is used broadly to include all the costs associated with a particular case, whether in the form of court fees, lawyer fees, or expenses of any kind.

2. See Goodhart, Costs, 38 YaLE L.J. 849 (1929).

3. For a proposal of studies of the rules of other countries, along with a scathing indictment of the American Rule, see Ehrenzweig, Shall Counsel Fees Be Allowed?, 26 CAL. ST. B.J. 107 (1951); Ehrenzweig, Reimbursement of Counsel Fees and the Great Society, 54 CAL. L. REV. 792 (1966). Following this challenge, the Committee on Comparative Procedure and Practice of the Section of International and Comparative Law of the American Bar Association sponsored a series of short reports covering four countries, which were published in the 1962 Proceedings of the Section of International and Comparative Law: Baeck, Imposition of Fees of Altomey of Prevailing Party Upon the Losing Party Under the Laws of Austria, 1962 A.B.A. SEC. INT'L \& COMP. L. 119; Baeck, Imposition of Legal Fees and Disbursements of Prevailing Party Upon the Losing Party-Under the Laws of Switzerland, 1962 A.B.A. SEC. INT'L \& COMP. L. 124 [hereinafter cited as Baeck, Imposition of Legal Fees and Disbursements]; Dietz, Payment of Court Costs by the Losing Party Under the Laws of Hungary, 1962 A.B.A. SeC. INT'L \& CoMP. L. 131; Freed, Payment of Court Costs by the Losing Party in France, 1962 A.B.A. SEC. INT'L \& COMP. L. 126; Schima, The Treatment of Costs and Fees of Procedure in the Austrian Law, 1962 A.B.A. SEC. INT'L \& COMP. L. 121; For a discussion contrasting American and European cost reimbursement rules, see R. Schlesinger, Comparative Law Cases, Text, Materials 343-44, 665-68 (4th ed. 1980). So far as the author has been able to determine, this list fairly exhausts the American literature on the comparative aspects of this subject.
} 
rule is concerned only with attorney fees and out-of-court expenses (rather than court costs), the article also places its focus there.

Also in keeping with the scope and objectives of the symposium, this article concentrates on the costs of civil litigation only. This means, most importantly, that the distribution of the cost burden in criminal cases is not considered. The unique nature of criminal procedure, where the participation of the individual is always involuntary, creates its own set of public policies, which, while certainly worthy of study, have almost nothing in common with the concerns that dominate this symposium.

Other limits on the scope of this article stem from the need to distinguish special types of civil cases. While Americans may be satisfied to regard as "civil litigation" everything that is left after the elimination of criminal proceedings, the same is not true in other countries. There is a bewildering variety of special courts, special jurisdictions, and special procedural rules: for various types of administrative law disputes, especially for those relating to social security and taxation; for labor law matters; for family matters; for various types of commercial matters; for maritime matters; for patent, copyright, and other industrial property matters; and, most recently, for various types of consumer transactions. That those special systems also include variations from the general rule on cost allocation should not come as a surprise to Americans, who have seen the emergence of exceptions to the American rule for special types of cases resulting from the special public policies influencing particular areas of the law. This article, however, makes no attempt either to provide exhaustive information on each and every special court in each of the countries discussed or to establish and consistently apply a uniform definition of "civil litigation" in the narrow sense. Principal attention is given to the rules established by the respective codes of civil procedure for "standard" cases comprising, at the core, contract, tort, and property disputes among individuals; reference is made, however, to modifications of the general rule with respect to special jurisdictions, matters, or procedures, especially when those deviations indicate differences in public policies or efforts to respond to the special equities of certain situations.

The pattern of rules and exceptions that thus emerges does not, of course, reflect any pattern of predominance in the actual numbers of cases handled by the courts. It seems, on the contrary, that much of the recent increase in the volume of litigation, in Europe at least, has been in the proliferating special jurisdictions, while the caseload of courts dealing with traditional types of civil litigation has remained relatively stable. 4 This article is not the place for an extensive comparative quantitative analysis of litigation volume, but there should be no need to emphasize that before any change in existing rules can be recommended, solid factual information is needed not only on the overall volume of cases in each jurisdiction but also on the natures and causes of the disputes, the types of parties

4. In a colloquium conducted recently by the German Bar Association on the problem of caseloads, it was reported that the caseloads of the courts of general jurisdiction for civil matters had actually declined while alarming increases had taken place in the administrative courts, the tax courts, and the Federal Constitutional Court. Redeker, Bewirtschaftung der Rechtsgewährung.?, 31 ANwaLTSBLATr 417 (1981). 
involved, and other factors that could be material in influencing litigation behavior.

Further, this particular audience is presumably interested in the practical effects of the rules as much as or more than in the abstract principles announced. This interest calls not only for a discussion of court rules and case law dealing with the interpretation and application of the general rule but also requires some basic background information on the manner in which the litigation services of a lawyer are needed, provided, and compensated in each country. Indeed, the principles governing the remuneration of lawyers for their services and the principles governing the allocation of costs among the parties are intricately interwoven, as is most persuasively demonstrated by the institution of contingent fees.

On the other hand, the objectives of the symposium do not require an exhaustive treatment covering all legal systems. A representative sample is enough to demonstrate the variety of situations, public policies, practical approaches, and problems existing outside the United States. This report looks at twelve European countries. Variety of approaches has been the principal factor in their selection. Other factors have been richness and accessibility of published material, language limitations, and research economics generally. Information is provided for the following countries: Austria, Belgium, Denmark, the Federal Republic of Germany, France, Italy, the Netherlands, Norway, Spain, Sweden, Switzerland (Cantons of Geneva and Zurich), and the United Kingdom (England and Wales).

Current discussion about the American rule seems to be concerned primarily with its effect on the behavior of prospective litigants. Specifically, it asks whether the rule is sufficiently effective in encouraging the "right" types of litigation and in discouraging undesirable types of litigation or litigation-related behavior (for example, delaying tactics or refusal to discharge legal obligations voluntarily). For a meaningful comparison, therefore, it seems useful to know how important a role concerns of this kind play in other legal systems. This report seeks to identify the principles that have traditionally governed the allocation of litigation costs as well as emerging concepts that provide a basis for questioning, modifying, or displacing the traditional notions.

The most powerful force to exert its influence in recent years has been the demand for equal access to justice. Indeed, it needs to be emphasized in these introductory paragraphs that the concern about equal access to justice has dominated the contemporary European literature to the extent that litigation costs are seen primarily as an impediment to equal access. Consequently, the principal standard by which cost allocation rules and proposals for their reform are evaluated is the extent to which they promote or impede equal access to the courts. ${ }^{5}$ Thus, while the current discussion provides many insights into the changing public policy of cost allocation and offers a number of suggestions for a differentiated approach for different types of cases, a certain amount of caution is needed in view

5. To say more about access to justice in this paper is neither possible nor necessary. The subject has been covered exhaustively by the first three volumes of ACCESS TO JusTICE (1978-79). The national reports compiled in the two books of the first volume ( $A$ World Survey) are especially helpful. Most of them contain some information on litigation costs and their allocation. 
of this explicit or implicit bias. Its benefit to the discussion in the United States is also limited by the fact that under the pressure for equal access to justice, an adoption of the principle of the American rule is rarely, if ever, considered as an alternative to the traditional European rules, except for certain special situations. That in itself can be taken as an indication of the continued strength of the European rules.

In contrast to the United States, where it has been difficult even to find a clear statement of the reasons why the courts have chosen to leave attorney fees and other expenses at the charge of each party, and where there has been little if any academic discussion of cost allocation, Europe has produced a body of legal literature on costs which is rich and almost overwhelming. The subjects of cost allocation, cost assessment, and cost procedure are important disciplines, to which legislatures, courts, and academic authors have devoted considerable thought. ${ }^{6}$ This article cannot do justice to the volume, complexity, and high level of scholarship of this discussion, especially considering that it extends over many centuries and many jurisdictions. It is only possible to give a rather rough and superficial account of the theoretical discussion. On the other hand, this article tries to present as many of the variations among the actual provisions as possible, in order to give American readers an impression of the wide range of possible approaches to the problem. The position of the author throughout is that of objective reporter and analyst rather than that of evaluator or advocate.

The article starts with a historical introduction, which seems necessary to explain the existing European rules and which shows a surprising parallelism between the concerns that dominate this symposium and concerns that were present at the earliest stage of the development of civil procedure. The second section of the article summarizes the existing rules in the twelve European countries listed above. The next sections deal with public policy, criticism, and reform proposals. The final section reports on some empirical data relating to the effects of costs on litigation behavior.

\section{II}

\section{Historical BACKGROUND}

With the exception of England and the Scandinavian countries, the countries of Europe can trace most of the principles governing civil procedure back to Roman law. It makes sense, therefore, to start this report by asking how the problem of allocating litigation costs was handled under Roman law in the various stages of its development. For obvious reasons, this cannot be more than a summary.

In the earliest stages, when civil procedure evolved as an organized, regulated, and objective form of enforcement and dispute settlement, first under the sponsor-

6. For a recent bibliography of major European monographs ranging from the eighteenth century to the 1960's, see Vecchione, Spese Giudiziali (Diritto processuale civile) in 17 Novissimo Digesto ITALIANO $1120-43$ (1970). Vecchione's article itself presents an excellent summary of the subject, including a historical and comparative discussion of the theoretical basis of cost allocation rules. 
ship of the high priests of Rome and then under that of the government, there were no costs in the contemporary sense. Specifically, there were no attorneys charging fees. Even in the classical period of Roman law during its first two centuries, when the famous Roman jurists wrote the commentaries and opinions that were to dominate legal thinking through our times, legal procedure and legal advice were free. ${ }^{7}$ The administration of justice still carried the dignity and the sacral aura of its religious origins.

Precisely because of these religious connotations, however, recourse to formal procedures was something not to be undertaken lightly and without good cause, and even the earliest forms of procedure had devices to ensure that. In the legis actio sacramentum, each party had to make a deposit (a sacramentum) into the temple at the time of the institution of the action; when a decision was rendered, the prevailing party had his deposit refunded, while that of the loser was forfeited to the temple. ${ }^{8}$ This type of procedure was already in use prior to the compilation of the Twelve Tables (around 450 B.C.); the Twelve Tables fixed the amount of the deposit at two levels corresponding to different amounts in controversy. ${ }^{9}$

During the early part of the classical period, there were a number of actions that provided for a doubling of the payment to be made to the plaintiff in the event that the defendant, rather than immediately acknowledging his obligation, denied the claim and thereupon by judgment was implicitly declared to have been lying. The cases for which this consequence (lis crescens in duplum) was provided were indeed of a kind suggesting bad faith especially in the case of the actio iudicati, which essentially constituted the enforcement of a previous judgment. The duplication was regarded as a penalty for litigating in bad faith (poena temere litigantium ). ${ }^{10}$ It has been noted that most of these actions amounted to a review of a decision already made. ${ }^{11}$

By the time of Justinian and the highly developed administrative style of the Byzantine Empire, only two of the actions for double payment were still in use. ${ }^{12}$ Lawyers, however, had started to charge fees, ${ }^{13}$ and despite some early efforts to outlaw the practice, ${ }^{14}$ a system of fees had developed to pay for the services of the officials that performed a variety of ancillary functions in an increasingly cumbersome judicial bureaucracy. ${ }^{15}$ As costs became a reality of life in litigation, with ever more detailed regulations determining their incidence and amounts, a prac-

7. See, e.g., L. Wenger, Institutes of the Roman LaW of Civil Procedure 330-31 (rev. ed. 1940).

8. See, e.g., Engelmann, The Roman Procedure, in A History of Continental Civil Procedure 239, 271 (R. Millar ed. \& trans. 1927).

9. For details, see M. von Bethmann-Hollweg, Der römische Civilprozess, Erster Band: Legis ACTIONES 121 (1864).

10. See L. WENGER, supra note 7, at 183-84.

11. Rudorff, Ueber die Liliscrescenz, 14 ZEITSCHRIFT Für GESCHICHTLICHE RECHTSWISSENSCHAFT 287 (1848).

12. Engelmann, supra note 8 , at 402 .

13. By the time of Diocletian (c. A.D. 300), it had become necessary to regulate them. See L. WENGER, supra note 7 , at 322 .

14. See M. von Bethmann-Hollweg, Der Römische Civilprozess, Dritter Band: CogniTIONES 200 (1866).

15. M. VON BETHMANN-HOLLWEG, supra note 14, at 200-04; L. WENGER, supra note 7, at 332. 
tice developed to require the losing party to reimburse the winner for his costs in cases of frivolous litigation and in cases of bad faith denial that formerly would have been punished by double recovery. ${ }^{16}$

Eventually, reimbursement of the prevailing party's costs became the rule for all cases and not just those involving bad faith. The East Roman emperor Zenon can be credited with announcing for the first time, in 486 A.D., ${ }^{17}$ the rule that the mere fact of losing was sufficient ground to impose on the loser the obligation to pay the winner's costs.

Fifty years later, the rule became part of the Code of Justinian. It was also adopted by the regional compilations for the western part of the Empire, ${ }^{18}$ then under the control of Germanic tribes but with the old administrative structure still largely in place. Justinian specifically required judges to decide on the costs in every case on which a final decision was made. ${ }^{19}$ This was important because the prevailing party had no other way to recover his costs-neither by appeal nor by separate action. Forgetful judges were declared personally liable for the costs. ${ }^{20}$

The controlling presumption was that the losing party had done wrong by insisting on its legal position, which, as the court's decision conclusively showed, was not justified. ${ }^{21}$ Accordingly, the judge was permitted to allow an exception when there were sufficient doubts to conclude that the losing party was in fact not guilty of bad faith. ${ }^{22}$ Thus, in effect, the Justinian rule reversed the relation of rule and exception. ${ }^{23}$

In this form, the rule was adopted by the ecclesiastical courts of the Roman Catholic Church and eventually by the courts of the emerging European nations. ${ }^{24}$ Further development at the national level, through court practice, literature, and legislation, produced some variation, especially with respect to the role and extent of judicial discretion and other exceptions. For example, the rules of the court of the German Empire, laid down in 1613, provided for exceptions on "satisfactory grounds." 25 During the nineteenth century, however, codifications enacted by the various German states generally left little room for discretion. ${ }^{26}$ The French Ordi-

16. L. WENGER, supra note 7 , at 333-34.

17. The decree is to be found in the Code of Justinian. CODE JusT. 7.51.5; see also L. Wenger, supra note 7 , at 334 .

18. For details and references, see M. von Bethmann-Hollweg, supra note 14, at 232; L. Wenger, supra note 7 , at 334 ;

19. Code JUST, 3.2.13.6 (a decree promulgated by Justinian in A.D. 530). It contains the often-cited words, "victum victori condemnandum" (the defeated is to be condemned [to pay] the victor).

20. This sanction appears already in Zenon's decree, CODE JUST. 7.51.5. See also M. VON BETHMANNHollWEG, supra note 14, at 232-33.

21. This has found expression in the text of the Institutes of Justinian. INST. JUST. 4.16 ("de poena temere litigantium").

22. This qualification also is expressed already in Zenon's decree. CODE JUST. 7.51.5; see also M. VON Bethmann-Hollweg, supra note 14 , at 232; W. Endemann, Das Deutsche ZivilprozessRecht 506 (1868 \& reprint 1969 ).

23. The sources are not altogether clear, and there is some disagreement among scholars on the extent to which the imposition of the costs was subject to conditions or discretion. See Vecchione, supra note 6 , at 1122 .

24. W. ENDEMANN, supra note 22 , at 507.

25. Id. at 508 .

26. See, for example, the following codes reprinted in NEUDRUCKE ZIVILPROZESSLALER KODIFIKATIONEN UND ENTWÜRFE DES 19. JAHRHUNDERTS: MATERIALIEN ZUR ENTWICKLUNGSGESCHICHTE DER 
nance of 1667 permitted no exception at all; this did not, however, deter the courts from splitting costs among the parties in appropriate cases simply by omitting reference to costs in their judgments, in open defiance of the statutory requirement that every judgment charge costs to the losing party. ${ }^{27}$

For England, the Roman law connection is less obvious, although it cannot be ignored. ${ }^{28}$ The English rules on costs developed in Law through piecemeal legislation and in Equity through the exercise of the Chancellor's discretion. Imposition of costs came into being as a special item of damages, in cases where damages were awarded. Apart from indemnification, the most important aim seems to have been to discourage frivolous or vexatious lawsuits. ${ }^{29}$

On the Continent, although the rule as such was never challenged, there was disagreement in the academic literature about its nature and place in legal theory. Some insisted that it was a penalty while others, emphasizing its compensatory function, regarded it as a form of damages. A third theory, pointing out that the pure and simple fact of losing a lawsuit was not enough to support either a penalty or a damage claim under generally accepted theory, viewed the cost consequences as a natural, generally known, and accepted incident of engaging in litigation. ${ }^{30}$ While it was also accepted that the prospect of becoming liable for the opponent's expenses acted as a deterrent against frivolous or hopeless claims or denials, one can detect misgivings concerning the potential deterrence of sound and legitimate claims. ${ }^{31}$

The most commonly accepted circumstances that could justify a deviation from the rule, especially a proportional division of the costs among the parties, were obscurity of facts, justified ignorance of material facts, mutual fault, exaggerated claims, and conflicting judgments at various levels of courts. ${ }^{32}$ Doubt or controversy concerning a question of law was not generally considered a sufficient reason for a partial shifting of the cost burden, nor could the loser obtain relief on the ground that the deciding judge had previously and repeatedly expressed a different opinion. ${ }^{33}$

The principles and attitudes on which European cost allocation rules are based

ZPO (Dahlmanns ed. 1971-1975): Baden (vol. 3) § 169; Bavaria (vol. 4) art. 106; Hanover (vol. 1) Code of $1847 \S 42$, Code of $1850 \S 46$.

27. Stein, From the 1500s to the Revolution: Procedure Under the Absolute Monarchy, in A HisTORY OF CONTInental Givil Procedure 708, 726 (R. Millar ed. \& trans. 1927).

28. For a discussion of the influence of canon law on procedural practice, see 1 F. POLLOCK \& F. Maitland, The History of English LaW 134 (2d ed. 1898 \& reprint 1923).

29. For details, see Goodhart, supra note 2, at 851-54. Scotland at first followed the Continental pattern, allowing the loser to escape the cost burden by showing that he had reasonable cause for the litigation; in the eighteenth century, however, it adopted the English position of always imposing costs on the loser except when the winner had engaged in improper conduct. 2 A. E. MACKAY, THE PRACTICE OF THE Court of SESSION 528-29 (1879).

30. For a summary of the law of the various German states in the eighteenth century, see Ehrig, Kostenerstattung-Erfolgsprämie oder Prozessstrafe?, 1971 ZeITSCHRIrT für RECHTSPOLITIK 252. For an overview of the discussion in the middle of the nineteenth century, see W. ENDEMANN, supra note 22, at 507-08. See generally Vecchione, supra note 6 , at $1122-30$.

31. W. ENDEMANN, supra note 22, at 508 .

32. Id. at 508-09.

33. Id. at 509 n.23. Endemann concludes his summary with the observation that despite all attempts at rationalization, the division of costs among the parties was not much more than a matter of sentiment. 
deserve more thorough analysis, of course. The proper place for that analysis, however, seems to be after an examination of existing rules themselves. ${ }^{34}$

\section{III}

\section{SUBSTANCE AND SCOPE OF THE RULES}

\section{A. Overview}

This section describes the existing law of twelve European countries in a form that is designed to facilitate comparison from an American perspective. The first aspect to be discussed is the content and scope of the general rule as it is established by statute and applied by the courts in each country, noting the effect of statutory exceptions or modifications and the range of discretion left to the courts. The second aspect is the definition, limitation, and determination of the costs affected by the rule. The third aspect involves special rules established for special jurisdictions, matters, or situations. The section concludes with a brief discussion of the interrelation of attorney fee shifting and European legal aid systems.

The relevant provisions of the laws or codes of the jurisdictions discussed here ${ }^{35}$ are provided in the Appendix in English translation. For the sake of brevity, the notes refer to those provisions only by name of the respective jurisdiction and section or article number.

There is no single concise rule that could be identified as the "European Rule." The rules of the various European countries concerning costs are neither uniform, nor simple, nor rigid. If any general statement can be made, it is that contrary to American tradition, most European countries (1) regard the objective fact of defeat as sufficient ground for imposing the costs on the losing party, without requiring any evidence of fault or bad faith, and (2) include in the costs to be reimbursed to the winner by the loser not only court fees and related costs but also the attorney fees and other expenses incurred by the winner. This general state-

34. To add perspective to the historical overview, it might be useful to remember that Roman law constitutes only one of the sources of present European law, the other major source being the traditions and customs of the various ethnic groups or tribes from which the European nations developed. Germanic tribal laws never reached the stage of development where costs and cost reimbursement would have received special attention; before coming under the influence of Roman law concepts, they did not even distinguish clearly between civil and criminal procedures. See 2 F. POLlOCK \& F. MaITland, supra note 28, at 572-73. This lack of sophistication does not mean that litigation was not expensive. Id. at 97. And in exacting an unequivocal and absolute commitment from litigants to the truthfulness and sincerity of their causes, the tribal laws were even more severe than ancient Roman law. In a system where difficult questions of fact were eventually resolved by battle between the opposing parties, the penalty for litigating in bad faith, or sometimes just for litigating unsuccessfully, was very harsh indeed. Even when milder forms of ordeal were used (such as carrying a red-hot iron or picking a ring out of a cauldron of boiling water), the losers often suffered permanent physical harm. See, e.g., Engelmann, The Medieval German Procedure, in A History or Continental Civil Procedure 85, 154-55 (R. Millar ed. \& trans. 1927); 2 F. POLlOCK \& F. MAITLAND, supra note 28, at 598-99. Compared to these consequences, the monetary sanctions imposed by Roman law and modern European codes appear in a different and more favorable light.

35. Among the twelve countries studied, there are two in which different rules apply in constituent parts or smaller jurisdictions. Thus, each of the 25 cantons of Switzerland has its own court system and code of civil procedure. The codes of Geneva and Zurich have been selected as examples. In the United Kingdom, there are separate but almost identical rules for England and Wales, Scotland, and Northern Ireland. Only the rules applicable to England and Wales are furnished in the Appendix and cited in the text. 
ment, however, needs to be qualified by reference to a complex system of definitions, limitations, exceptions, and grants of discretion in each of the jurisdictions.

Even the general rule just described does not apply in every country. A notable exception is Spain, whose code of civil procedure, enacted in 1881, does not mention the subject of costs at all in the context of ordinary judgments and thus neither requires courts generally to make a decision on the costs nor has a general rule charging the costs to the losing party. ${ }^{36}$ On the other hand, there are many special provisions scattered throughout the code that provide for costs in specific types of matters or cases to be charged to the losing party. ${ }^{37}$ With this approach, the code continues a tradition of Spanish law under which, absent a special provision to the contrary, the losing party could be ordered to pay costs only if found guilty of temerity or bad faith. ${ }^{38}$ This position, however, has increasingly been challenged on the ground that it makes it too difficult and too inconvenient for the courts to charge costs to the losing party. ${ }^{39}$ Instead, the prevailing view in the literature seems to be that the established doctrine should be replaced by the principle of "objective defeat." 40

Significantly, the Municipal Court Act of 1944 adopted the objective principle as the general rule for all cases in the jurisdiction of the municipal courts. ${ }^{41}$ And in January 1983, the General Commission for Codification (a legislative reform commission operating under the auspices of the Department of Justice) adopted a preliminary draft for amendments to the code of civil procedure containing a provision expressly establishing the objective principle. ${ }^{42}$

\section{B. Imposition of Costs on Losing Party}

1. Duty of Court. With the exception of Spain, just mentioned, and England, where the court is given discretion whether to rule on costs, ${ }^{43}$ the codes specifically

36. For an extensive treatment, see Miguel y Alonso, Los costos y las costas en el proceso civil español, 1969 REVISTA DE DERECHO PROCESAL IBEROAMERICANA 901, and for a summary: Murray $A$ Survey of Civil Procedure in Spain and Some Comparisons with Civil Procedure in the United States, 37 TULANE L. REV. 399, 450-52 (1963).

37. Spain (a), Author's Statutory Appendix [hereinafter cited as App.] 117; see also F. RAMOS MENDEZ, DERECHO PROCESAL CIVIL 648 (1980).

38. See, e.g., Tribunal Supremo, May 21, 1963, Aranzadi 2745.

39. Miguel y Alonso, supra note 36; Miguel y Alonso, Access 10 Justice in Spanish Law, in 1 ACCESS TO Justice 845, 868-69 (1978). Spanish judicial statistics, like those of other countries, do not allow reliable conclusions concerning the number of cases in which costs are imposed on one of the parties, and on what grounds.

40. See works of Miguel y Alonso, cited supra note 38; see also F. RAMOS MENDEZ, supra note 37, at 648. "Objective defeat" indicates the absence of subjective elements such as fault, negligence, or bad faith; the term thus parallels that of "objective liability," which is roughly analogous to strict liability in American usage.

41. Spain (B), App. 119.

42. Letter from Carlos de Miguel y Alonso to Werner Pfennigstorf (Feb. 16, 1983). The text of the proposed new provision is:

In proceedings for judgment, the costs of the trial court stage are imposed on the party whose claims have been completely rejected, except insofar as the judge considers the presence of exceptional circumstances justifying that they be not imposed. If the success or rejection was partial, each party shall pay the costs caused by it, and one-half of the common costs.

A similar provision is planned to be included (as article 449) in a new code of civil procedure, on which the commission is still working. Id.

43. England (a) $\$ 51(1)$, App. 92. It will be seen that in practice this discretion is rather limited. 
prescribe that the courts shall impose costs on the defeated party. ${ }^{44}$ Many of the codes specifically provide that this decision is to be made by the court on its own motion if the prevailing party has failed to submit a petition for the ruling. ${ }^{45}$

The rule is generally applied whether the defeated party is the plaintiff or the defendant, although rarely is this spelled out in the code. ${ }^{46}$ Thus, in contemporary American parlance, the European codes prescribe "two-way fee shifting."

"Defeat" is usually understood to mean complete defeat in all major aspects of the case; it is, therefore, not an exception to the rule, but only a clarification, where a code provides that if a party prevails in some respects but loses in other respects, the costs are to be divided proportionately. ${ }^{4}$

One of the more important cases of a partial victory is a judgment giving a plaintiff less than the precise amount requested. It is generally recognized that, with respect to the difference between the amount claimed and the amount awarded, the plaintiff has lost and must bear a proportionate part of the total $\operatorname{costs}^{48}$ Some codes specifically provide that costs need not be divided if the difference was minor and did not cause any additional costs. ${ }^{49}$ It is easy to see how this particular rule discourages plaintiffs from making unrealistically large damage claims. There are, of course, instances when it is impossible to calculate a damage claim with absolute precision, but the European codes offer a sufficient variety of procedural devices to prevent hardship in such cases. ${ }^{50}$

It is a confirmation of, rather than an exception to, the rule where the codes provide that in the event of a settlement in court, costs are split between the parties unless, of course, the terms of the settlement provide otherwise. ${ }^{51}$

The English rules on this point are different and deserve special note. Ordinarily, a plaintiff is entitled to his full costs even if the court awards him less than the amount claimed, except where some personal misconduct was involved in pur-

44. Austria § 41, App. 85; Belgium art. 1017, App. 89; Denmark § 312(1), App. 90; France art. 696, App. 102; Geneva art. 122(1), App. 104; Germany $\S 91(1)$, App. 106; Italy art. 91 , App. 110 ; Netherlands art. 56, App. 112; Norway $\S 172$, App. 114; Spain (b), App. 119; Sweden ch. 18, § 1, App. 119; Zurich §64, App. 123.

45. Austria § 52(3), App. 88; Belgium art. 1017, App. 89; Netherlands art. 56(4), App. 122. The opposite rule (costs only on request) prevails elsewhere. See Norway $\S 179$, App. 116; Sweden ch. $18 \S 14$, App. 122; see also Baeck, Imposition of Legal Fees and Disbursements, supra note 3 . Some of the codes that require no petition do nevertheless require submission of a statement of expenses to avoid forfeiture of the right to reimbursement. See, e.g., Austria $\S 54(1)$, App. 88.

46. Most of the codes refer generally to the winning or losing party. Denmark $\S 313$, App. 91, provides specifically that an action that is dismissed entirely is deemed to be lost by the plaintiff for purposes of cost reimbursement.

47. See, e.g., Austria $\S 43$, App. 86; Norway $\S 174$, App. 115. Some codes authorize the court to apportion costs in such cases. Italy art. 92, App. 111; Netherlands art. 56(1), App. 112.

48. See, e.g., Austria $\S 43(1)$, App. 86; Denmark $\S 316(1)$, App. 91; Germany $\S 92(1)$, App. 107; Zurich $\S 64$, App. 123 .

49. Austria § 43(2), App. 86; Denmark § 316(2), App. 91; Germany § 92(2), App. 107; Norway $§ 174$, App. 115.

50. They include, among other things, petitions for an indeterminant amount or an amount left to be determined by the court, and split actions aimed at establishing in a first stage the basis of liability and determining in a second stage the amount of damages with separate valuation. See also Zurich $\S 64$, App. 123.

51. Austria $\S 47(1)$, App. 87 ; Germany $\S 98$, App. 109; Italy art. 92, App. 111 
suing the excess claim. ${ }^{52}$ The defendant may, however, shift the cost risk partially to the plaintiff by "paying into court" an amount essentially constituting his settlement offer, which the plaintiff may either accept or reject. If the plaintiff accepts, the case is terminated, and the plaintiff is entitled to his costs. If he holds out for a higher award from the court and is successful, he is also entitled to his costs for the full amount of the judgment, but if the judgment is only equal to or lower than the amount paid into court, the plaintiff, even though essentially successful, must reimburse defendant for costs incurred after the time of the payment into court. ${ }^{53}$ The aim is to encourage settlement. ${ }^{54}$

2. Judicial Discretion. Although the role and scope of judicial discretion seem at first glance to be where the European codes differ most from one another, appearances can be deceiving. For instance, the codes of Austria, Germany, and the Netherlands appear to be the most rigid ones, instructing the court to impose costs on the defeated party, with no option to deviate. ${ }^{55}$ The English rule, in contrast, appears to be the most liberal one, expressly giving the court full discretion not only "to determine by whom and to what extent the costs are to be paid" but even whether to rule on costs at all. ${ }^{56}$ A closer look reveals, however, that an English court's discretion is limited by the rules of procedure (to which the Supreme Court Act expressly refers) and by case law. The rules of procedure specify, in accordance with longstanding tradition, that the courts "shall . . . order the costs to follow the event," unless the circumstances of the case justify a different allocation. ${ }^{57}$ And the cases leave no doubt that the discretion is to be exercised "judiciously" 58 and that "where a plaintiff comes to enforce a legal right, and there has been no misconduct on his part, . . . the court has no discretion, and cannot take

52. See, e.g., Pearman v. Baroness Burdett-Coutts, 3 T.L.R. 719, 720 (1887) (plaintiff denied costs after claiming $£ 600$ and recovering only $£ 50$ ); Huxley v. West London Extension Ry., 17 Q.B.D. 373,374 (1886) (token recovery after "extravagant" claims). In both cases, the court made a point of stating that a "good cause" was needed to deny costs to the successful plaintiff, that the difference between amount claimed and amount recovered did not by itself constitute a good cause, and that in the cases decided a good cause was provided by the fact that the plaintiffs had supported their exaggerated claims with allegations of facts known to be untrue. The courts have not gone so far as to order the plaintiff to pay the defendant's costs in these cases.

The cases involving overstated claims must be distinguished from cases involving several issues. If in such cases each party wins some issues and loses others, the costs are to be apportioned according to the outcome on each individual issue. See D. Casson \& I. Dennis, Odgers' Principles of Pleading and Practice in Civil Actions in the High Court of Justice 378-79 (22d ed. 1981) [hereinafter cited as ODGERS].

53. For details, see ODGERs, supra note 52, at 379.

54. For a detailed discussion of this rule and its effects on the decisions to be made by the parties, see Zander, Is the English Payment-into-Court Rule Worth Copying?, 40 RABELS ZeITSCHRIFT für AUSLÄNDISCHES und internationales Privatrecht 750 (1976).

55. Austria $\S 41(1)$, App. 85; Germany $\S 91(1)$, App. 106; Netherlands art. 56(1), App. 112 (qualified with respect to unnecessary expenses).

56. England (a) $\S 51(1)$, App. 92. An almost identical provision applies to Northern Ireland. Judicature (Northern Ireland) Act, $1978 \mathrm{ch} .23, \S 59$. In Scotland, the same principle is firmly established by case law. See D. Walker, The Scottish Legal System: An Introduction to the Study Of SCOtS Law 296-97 (4th rev. ed. 1976).

57. England (b) 0.62 r. 3(2), App. 93.

58. See, e.g., Donala Campbell \& Co. v. Pollack, 1927 A.C. 732, 811-12. 
away the plaintiff's right to the costs." 59 Nor may the court impose costs on a third person who is not a party. ${ }^{60}$

Thus, the English rules of procedure recognize a rather limited number of exceptions to the rule that costs follow the event. The range of exceptions is actually narrower in England than under the rigid statutory rules of Austria or Germany, as will be seen when the various exceptions are discussed in detail.

French courts, as noted, ${ }^{61}$ have always claimed discretion to deviate from the strict "loser-pays-all" rule under special circumstances, even in defiance of statutory prohibition; and an amendment to the code in 1958 finally recognized this. ${ }^{62}$ The present version of the code still requires the losing party to be ordered to pay the costs but qualifies this by the proviso, "unless the court, by decision accompanied by reasons, orders otherwise." The code provides no guidance for the exercise of this discretion, but it is understood that no change in substance was intended and that the courts were expected to continue to apply the standards developed over the years. The requirement that reasons be given allows the exercise of discretion to be reviewed, as it had been before. ${ }^{63}$

The Italian code also gives the court wide discretion, permitting it to aportion costs among the parties in the presence of good reasons (giusti motivi). ${ }^{64}$ Similar rules can be found in many cantons of Switzerland. For instance, the code of Zurich, most recently revised in 1976, provides that "as a rule" costs are to be charged to the losing party and to be divided proportionately if neither party succeeds completely and then specifies two cases in which the court may "especially" deviate from that rule. ${ }^{65}$

Among the Scandinavian countries, Denmark is most generous in allowing the court to deviate from the general rule under "special circumstances"; 66 the codes of Norway and Sweden are more precise in defining the court's discretion. Norway allows costs to be split among the parties when there was sufficient doubt in the case to justify the losing party's decision to litigate. ${ }^{67}$ A similar formula was used in the old Swedish code of $1743 ;^{68}$ it was, however, replaced in the new code of 1948 by a provision that orders or allows costs to be split when either the pre-

59. Cooper v. Whittingham, $15 \mathrm{Ch}$. D. 501 (1880). For more references, see OdGERs, supra note 52, at 370-71; Goodhart, supra note 2, at 861-62.

60. Forbes-Smith v. Forbes-Smith, 1901 P. 258, 271.

61. See supra note 26.

62. 1958 Journal Officiel de la République Française [J.O.] 11608, art. 3, 1959 Recueil Dalloz Legislation [D.L.] 45. (amending art. 130 of the (old) Code de procedure civile). The complete revision of 1971, which produced the new Code de procédure civile, changed the numbering (to art. 696) and the language, but not the substance of the provision.

63. See, for example, the article on Frais et dépens in 2 RÉPERTOIRE DE PROCÉDURE CIVILE IT 387 -

88 (2d ed. 1979) [hereinafter cited as RÉPERTOIRE].

64. See Italy art. 92, App. 111.

65. Zurich $\S 64$, App. 123. Article III(3) of the code of Fribourg (1953) authorizes the court to deviate for "clearly established reasons of equity." See also W. HABSCHEID, DROIT JUDICIAIRE PRIVÉ SUISSE 296 (2d ed. 1981); Baeck, Imposition of Legal Fees and Disbursements, supra note 3.

66. Denmark § 312(1), App. 90; see also H. Munch-Petersen, Der Zivilprozess Dänemarks 13536 (1932 \& reprint 1970).

67. Norway $\S 172$, App. 114.

68. See R. Ginsburg \& A. Bruzelius, Civil Procedure in Sweden 367-68 (1965); R. Wrede, Das ZIVILPROZESSRECHT SCHWEDENS UND FINNLANDS 363 (1924 \& reprint 1970); 
vailing party engaged in litigation without provocation or otherwise unnecessarily or the losing party was justifiably ignorant of material facts. ${ }^{69}$

3. Qualifications and Exceptions. While it is generally recognized that the objective fact of defeat is a sufficient ground for imposing costs on the losing party, it is equally well recognized that this rule needs to be qualified and exceptions to be made for certain situations. It is in the definition and application of these qualifications and exceptions where one can observe the conflicting policies of cost allocation in all their complexity, as well as the variety of possible responses, reflecting the diverse cultural and legal traditions of the various European countries. Some of the exceptions are established by statute, others have been developed by the courts. Some retain the classic notion of presumed bad faith, absolving the loser from the cost burden if he can rebut the presumption. Others reflect policy considerations far removed from those that govern the general rule.

For a full understanding of the working of European rules one would have to know not only that exceptions are recognized and how they are defined but also to what extent they are actually applied, and specifically in what percentage of the cases actually decided the cost decision follows the exception rather than the rule. Observation of the cases might reveal that the exceptions have for practical purposes replaced the rule.

Unfortunately, the standard court statistics do not collect data on which such an analysis could be based. Practitioners working in the various systems are reluctant even to venture estimates. The general impression that one gets from reading the statutes, cases, and literature, however, is that the exceptions are indeed exceptions and that most cases are decided according to the rule.

The following is a summary of the most common types of exceptions.

a. Unprovoked action. If a defendant who has not provoked the plaintiff's resort to legal action recognizes the plaintiff's claim immediately, demonstrating thereby that the action was unnecessary, he is usually not only freed of the obligation to pay the plaintiff's costs ${ }^{70}$ but the plaintiff, although technically the winner, may be ordered to pay the defendant's expenses. ${ }^{71}$

b. Excusable ignorance of material facts. If the plaintiff prevails on the basis of facts that the defendant did not know and could not have been expected to know prior to the commencement of the action, the Swedish code permits costs to be split among the parties. ${ }^{72}$

c. Substantial mutual doubts about facts. Such doubts may justify either party's litigating in good faith and thus also justify a decision to split the costs between

69. Sweden ch. 18, § 3, App. 120; see also R. Ginsburg \& A. BRuzelius, supra note 68, at 367-68. The change has been criticized for placing too narrow limits on the court's discretion. Id. at 368 n.4.

70. E.g., Sweden ch. 18, § 3, App. 120.

71. Austria $\S 45$, App. 86; Denmark $\S 312(5)$, App. 91; Germany $\S 93$, App. 107; Norway $\S 173$, App. 115.

72. Sweden ch. 18, § 3, App. 120. 
winner and loser. ${ }^{73}$ A special case that is occasionally mentioned in this context is that of disagreement about the interpretation of a contract made between the two parties. ${ }^{74}$

d. Doubts about the law. Courts and legislatures have been much more reluctant to recognize doubts about the law as a basis for deviation from the general rule. Only the Norwegian code seems to permit a splitting of costs generally in the event of legal doubts. ${ }^{75}$ In other countries, commentators have expressly pointed out that legal doubts do not qualify as an exception. ${ }^{76}$ In the special and rather persuasive case of a decisive change in legislation or case law intervening while the case is pending, Italian courts have recognized giusti motivi as an exception. ${ }^{77}$ Austrian and German courts are divided on the question whether a departure from the rule is justified when the outcome of the case is changed by legislation occurring after the trial but before the judgment or even after the first appeal judgment. ${ }^{78}$

e. Appeals. A special challenge to the rule that the costs must follow the event is presented by decisions of higher courts on appeal. It seems fair that if its appeal is rejected, the defeated party should be charged with all costs of trial and appeal. If, on the other hand, the appeal is successful, and the decision of the lower court is reversed, the party that prevailed at the lower level and only lost on appeal can argue that at least one court did agree with its position, which therefore cannot be all wrong. The argument becomes even more persuasive when a case is appealed further and then perhaps remanded for new trial. Yet, the general rule is that all costs incurred at all levels follow the eventual outcome of the case. ${ }^{79}$

There is one important exception: If an appellate decision is based on new facts that could have been presented in the lower court (and presumably would have made the appeal unnecessary), costs of the appeal can be charged against the prevailing party. ${ }^{80}$ Further, when the code gives the court discretion to divide

73. For Denmark, see H. Munch-PETERSEN, supra note 66, at 135. A similar provision existed in Sweden prior to 1948. See R. GinsBuRg \& A. BRUZELIUS, supra note 68, at 367-68; R. WREDE, supra note 68 , at 363. The Italian courts have recognized the difficulty of the matter as good cause for a division of costs. See M. Cappelletti \& J. Perillo, Civil Procedure in Italy 248 n.59 (1965).

74. For Italy, see V. ANDRIOLI, RASSEGNA DI GIURISPRUDENZA SUL CODICE DI PROCEDURA CIVILE, Libro Primo 374 (1954); for Denmark, see H. MUNCh-PETERSEN, supra note 66, at 135.

75. Norway $\S 172$, App. 114. A similar provision of the pre-1948 Swedish code had been interpreted as applicable to legal as well as factual obscurity. See R. GinsBURg \& A. BRUzELIUS, supra note 68, at $267-$ 68.

76. See, e.g., H. MUNCH-PETERSEN, supra note 66, at 135. See generally W. ENDEMANN, supra note 22 , at 509 .

77. For references, see V. ANDRIOLI, supra note 74.

78. Compare 5 Entscheidungen des Österr. Obersten Gerichtshofes in Zivil- Und JusTIZVER WALTUNGSSACHEN 128 (1923) and Landgericht Wien, 1934 Zentralblatt f.d. jur. Praxis No. 369 with 101 Entscheidungen des Reichsgerichts in Zivilsachen 162 (1920) and Bundesgerichtshof 37 Entscheidungen des Bundesgerichtshofs in Zivilsachen 233 (1962). The German court has also refused to allow an exception from the rule when a statute on which the trial court and court of appeals have based their decisions is subsequently declared unconstitutional. Bundesgerichtshof (Ib Zivilsenat), Oct. 9, 1964,1965 NEUE JURISTISCHE WOCHENSCHRIFT 296.

79. For express provisions to this effect, see Austria $\S 50$, App. 87; Denmark $§ 318$, App. 91 ; Germany $\S 97(1)$, App. 109; Sweden ch. 18, § 15, App. 122.

80. Germany $\S 97(2)$, App. 109. For England, see OdGERs, supra note 52, at 382. 
costs in deviation from the rule, that discretion applies also to the appellate court. Also, appeals on side issues that do not affect the principal cause are usually treated separately with respect to costs. ${ }^{81}$

f. Vexatious actions. A peculiar type of case appears in English case law. A court, though unable on legal grounds to dismiss an action, finds it to be oppressive or vexatious and therefore, in addition to awarding only minimal or token damages, it punishes the plaintiff by denying him reimbursement for his costs. ${ }^{82}$

g. Unnecessary procedures. An important qualification of the general rule on costs (rather than an exception in the strict sense) is that the prevailing party is entitled to reimbursement only for those costs that were necessary to obtain a favorable decision. ${ }^{83}$ The effects of this qualification are manifested in two ways: first, in the form of limitations on the types and amounts of reimbursable expenses, which will be discussed later, ${ }^{84}$ and second, in the form of rules denying a winner reimbursement for any expenses related to procedures that where not strictly needed. In this latter sense, limiting application of the fee shifting rule to necessary costs has made the cost decision a preferred tool for the promotion of procedural economy and for the enforcement of the duty of good faith, openness, and cooperation in litigation. ${ }^{85}$

Consequently, if a party causes costs by unnecessary or uneconomical procedural acts or motions, it is not only barred from demanding reimbursement for its own costs but also must reimburse the other party, regardless of the outcome. ${ }^{86}$ Specifically mentioned is conduct that causes delay, postponement, or adjournment of hearings or trials, ${ }^{87}$ and delayed presentation of material facts or arguments, which, if timely presented, would have led to more expeditious disposition of the case. ${ }^{88}$ A typical case in this class would be that of a defendant who upon failing to appear at the first hearing loses by default judgment but later presents a good defense and thereupon wins reinstatement and dismissal. He would have to bear the costs attributable to the default proceedings. The English rule on pay-

81. Denmark § 320(1), App. 92; Germany §96, App. 109; Sweden ch. 18, § 15, App. 122.

82. For details and references, see ODGERs, supra note 52, at 371 .

83. The element of necessity is expressly stated in Austria $\S 41$ (1), App. 85; Denmark § 312(2), App. 91; England (b) O. 62 r. 28(2), App. 97; Geneva art. 122(2), App. 104; Germany \$ 91(1), App. 106; Zurich $\S 66$, App. 123. Other countries use other methods to control the amount of reimbursable costs. See infra text accompanying note 112 .

84. See infra pp. 55-59.

85. The duty is generally recognized but rarely expressly established by statute. An express statement can be found in the Italian code, CODICE DI PROCEDURA CIVILE, art. 88:

The parties and their attorneys have the duty to comport themselves in court with honesty and probity.

Regio decreto of Oct. 28, 1940, No. 1443.

86. Austria $\S \S 44,48$, App. 86-87; Germany $\S 95$, App. 109; Italy art. 92, App. 111 ; Netherlands art. 56(1), App. 112; Norway $\S 177$, App. 116; Sweden ch. 18, §6, App. 120; Zurich $\S 66$, App. 123. In Belgium, this consequence is not spelled out in the code but is recognized by the courts. See A. FETTWEIS, A. KoHl \& G. DE Leval, Droit Judiciaire PRIVÉ 428 (4th ed. 1976).

87. Austria $\S 48(1)$, App. 87; Denmark $§ 319$, App. 92; Germany $§ 95$, App. 109; Norway $\S 177$, App. 116; Sweden ch. $18 \S 6$, App. 120.

88. Austria $\S 55$, App. 89. 
ments into court also belongs in this context. ${ }^{89}$

As enforcement tools, these rules have a distinctive punitive character. This appears clearly in the Italian provision authorizing the court to impose on the offending party cost items that ordinarily would not be reimbursable, ${ }^{90}$ and by the provision of the Norwegian code, which allows courts to punish parties who have "conducted the case against better judgment" by imposing on them all the opposing party's costs, whether necessary or not. ${ }^{91}$

Punishment is also the dominant motive in the Austrian provision allowing the court to impose on a party guilty of belated presentation of material facts or arguments not just the costs occasioned by the delay, but the total litigation costs. ${ }^{92}$ This is a punishment that benefits the opponent, who ordinarily would have had to bear at least part of the costs. German law distinguishes more clearly between indemnification and punishment for procedural misconduct. It authorizes the court to order parties guilty of dilatory conduct to pay to the court a special penalty, expressed in statutory court fee units. This penalty is completely independent of the allocation of costs and, significantly, the provision authorizing it is not among the cost allocation rules of the code of civil procedure but rather is in the act regulating the types, incidence, determination, and collection of court fees. ${ }^{93}$

Where imposition of costs becomes a pure penalty for misconduct it need no longer be limited to the parties themselves. Indeed, several codes provide that costs caused by unnecessary procedures can be imposed on the attorneys or representatives who negligently initiated the procedures. ${ }^{94}$

The Austrian provision deserves special mention because it singles out, as specific examples of attorney misconduct, the inclusion of nonmaterial facts or surplusage in the briefs. ${ }^{95}$ The punishment for such misconduct, however, is to be imposed only in the event of gross negligence. Similarly, guardians, administrators, and persons with similar responsibilities may also be ordered to bear costs personally. ${ }^{96}$ The Zurich code refers to witnesses and to third persons generally. ${ }^{97}$

89. See supra text accompanying notes $52-54$.

90. Italy art. 92, App. 111 (referring specifically to art. 88); see supra note 85 .

91. Norway $\S 176(1)$, App. 115.

92. Austria $\S 44$, App. 86.

93. This provision, appropriately, appears not in the code of civil procedure but in the act dealing with court fees:

(1) If in cases other than that of $\S 335$ of the code of civil procedure, through the fault of the plaintiff, the defendant, or a representative, it becomes necessary to adjourn a trial or to set a new date for a trial, or if the disposition of the case has been delayed by late presentation of means of offense or defense or of evidence or objections to evidence that could have been presented earlier, the court may on its own motion impose on the plaintiff or on the defendant a special fee in the amount of one fee unit. The fee may be reduced to one-quarter. What is provided for the plaintiff, the defendant, and the representative shall also apply to intervenors, to third parties participating in the trial, the Chief Federal Attorney, the attorney representing the public interest, and the representatives of these persons.

Gerichtskostengesetz § 34, 1975 Bundesgesetzblatt[BGBl] I 3047 (translation by Werner Pfennigstorf).

94. Austria $\S 49$, App. 87; Denmark $\S 321$, App. 92; France art. 697, App. 102; Netherlands art. 58, App. 113.

95. Austria $\S 49(2)$, App. 87.

96. Geneva art. 127, App. 104; Italy art. 94, App. 111.

97. Zurich $\$ 66$, App. 123. 
As a logical extension of these principles, some codes provide for costs to be charged to the courts themselves if caused by inappropriate handling of the case. ${ }^{98}$

It should be noted in this context that the procedural cost rules and penalties are not the only sanctions for misconduct. Dishonest or deceitful conduct before or during litigation may also result in liability for damages under substantive law. Some codes specifically refer to this possibility. ${ }^{99}$

h. Actions among relatives. A rule that cannot be explained as evidence of surviving penal or tort elements is the division of costs regardless of the outcome among parties who are related to each other by blood or marriage. ${ }^{100}$ The Belgian and Dutch codes contain express provisions to this effect; ${ }^{101}$ the new French code retains the principle implicitly, having replaced an express provision with one giving the court general discretion. ${ }^{102}$ The rationale here seems to be to let the court give due consideration to the special economic and social ties and dependencies that of ten exist among relatives.

i. Matters not subject to party disposition. A final and very noteworthy exception applies to matters in which the law requires a formal decision by the court and will not recognize private agreements or settlements among the affected parties. Principal in this class are decisions concerning family status, and among them the most prominent are divorces, specifically those of the uncontested or no-fault types. In these cases, when the law for reasons of public policy imposes a quasi-litigation procedure as a condition for achieving results that do not involve a real dispute, one may ask whether the cost burden associated with that procedure is justified at all; and it seems all the more unfair to place the burden entirely on one of the parties who happens technically to be the loser. Specifically in the case of no-fault divorces, it would add injury to insult if a spouse who is allowed to seek dissolution of a marriage without having to prove any fault or wrongdoing on the part of the other spouse, could then, after having achieved his purpose, also demand reimbursement of his legal expenses. Consequently, several of the European codes have been amended in recent years to permit costs in such cases to be charged entirely to the plaintiff or to be divided between the parties at the discretion of the court. ${ }^{103}$ Sweden has a general provision to that effect applicable to all cases when a court decision is required and when the result is not at the disposition of the parties. ${ }^{104}$ True to the underlying philosophy of this rule, the courts have charged all costs to 123.

98. Austria $\S 51(2)$, App. 87; Denmark $\S 322$, App. 92; France art. 698, App. 102; Zurich $\S 66$, App.

99. Italy art. 96, App. 111; Norway $§ 177$, App. 116.

100. See generally W. ENDEMANN, supra note 22, at 509.

101. Belgium art. 1017, App. 89; Netherlands art. 56(1), App. 112.

102. Article 131 of the old French code was identical to the second paragraph of Belgium art. 1017, App. 89. This special provision was no longer needed after the enactment of article 696 of the new code.

103. Austria $\S 45 a(1)$, App. 86; Germany $\S 93 a$, App. 107. For Belgium, see art. 1286(b) of the Code judiciaire, added by law of July 1, 1974, Moniteur Belge, Aug. 17, 1974, art. 11. England has a simplified procedure for uncontested divorces that does not require representation by lawyers. See Jacob, Access to Justice in England, in 1 ACCESS TO JUSTICE, 417, 454 (1978).

104. Sweden ch. $18 \S 2$, App. 120. These cases are known as indispositiv cases. For an explanation of the concept, see R. Ginsburg \& A. Bruzelius, supra note 68, at 139. 
the loser in cases that, although technically within this indispositiv class, are more akin to regular adversary matters, notably paternity suits and divorce suits based on adultery. ${ }^{105}$

4. Residual Cost Decision. If the principal issue is resolved or ceases to exist without reaching the stage of judgment or final settlement, the issue of costs usually survives alone, and the court has to make the allocation on the basis of a hypothetical decision considering the state of the facts and arguments at the time the case was discontinued. ${ }^{106}$

5. Appellate Review. In most jurisdictions, the court's decision concerning the allocation of costs is subject to review as a part of the judgment. In France, the new provision allowing the court to deviate from the statutory rule but requiring a statement of the reasons therefor has been interpreted as having precisely the purpose of permitting review. In contrast, the court's decision to follow the rule by imposing costs on the losing party is thought to need no statement of reasons except where the issue was raised and argued by the parties. ${ }^{107}$

Separate appeal of the cost decision without also appealing the decision of the principal issue is restricted in some jurisdictions. It is expressly precluded in Germany and Norway. ${ }^{108}$ The Austrian code precludes it when the decision has been made by a court of appeals. ${ }^{109}$ When separate appeal is available in Austria and Germany, it is the limited appeal, subject to short time limits and decided without hearing, available for orders of the court. ${ }^{110}$

\section{Determination of Reimbursable Costs}

1. Procedure. There are two basic approaches: In some jurisdictions, the court, in the judgment, decides on the allocation of the costs in general terms, specifying which party has to bear the total costs or which fraction of the total cost has to be borne by one or the other party. In these cases the precise amount of the costs to be reimbursed by one party to the other is determined later by court officials. This group includes England, Germany, and Italy. ${ }^{111}$

In the second group of jurisdictions, the court itself specifies the reimbursable amount in the judgment. ${ }^{112}$ This requires that the parties submit their statements

105. R. Ginsburg \& A. BRUzelius, supra note 68 , at 371 n.25.

106. Denmark $\S 312(4)$, App. 91; Germany $\S 91$ a, App. 106; see also Norway $\S 175$, App. 115; Zurich $\S 65$, App. 123.

107. 2 RÉPERTOIRE, supra note 63, \ 366.

108. Germany $\S 99(1)$, App. 110; Norway $\S 181$, App. 117 (the second paragraph of $\S 181$ provides an exception when a violation of the law is alleged). Germany $\S 99(2)$ provides an exception when the principal issue has been decided on the basis of a formal acknowledgement, precluding appeal. Another exception in Germany is that of section $91 \mathrm{a}$, App. 106, applicable when the principal issue has ceased to exist.

109. Zivilprozessordnung [ZPO] $\S 528(1), 1895$ Reichsgesetzblatt [RGBI] Nr. 113.

110. Austria $\S 55$, App. 89; $\$ 91(2)$, App. 106; Germany $\S 99(2)$, App. 110 . The restricted nature of the "limited appeal" (sofortige Beschwerde) of the German code is not spelled out in the cost provisions but in the provisions dealing generally with appeals from procedural orders. Zivilprozessordnung $\$ 577,1950$ BGBI S. 533.

111. England (b) O. 62 rr. 26-32, App. 97-101; Germany $\S 103(2)$, App. 110; Italy art. 91, App. 110

112. Austria $\S 53$, App. 88; Denmark §312(2), App. 91; Netherlands art. 56(3), App. 112; Norway $\S 179$, App. 116; Sweden ch. 18, § 14, App. 122; Zurich § 69, App. 124. 
of expenses a reasonable time before the judgment is announced. While some codes provide for later adjustments, ${ }^{113}$ others expressly provide that the assessment by the court is final and not subject to review or adjustment. ${ }^{114}$

The French code differentiates between court costs which are assessed by the court in the judgment ${ }^{115}$ and other expenses incurred by the victorious party which are assessed by the office of the court. ${ }^{116}$ In Belgium the parties have the option of submitting a statement before the conclusion of the case, in which case the court specifies the amount to be reimbursed in the judgment, or of submitting a petition and a statement after judgment is rendered and having a judge decide on the amount at that time. ${ }^{117}$

2. Definition and Limitation of Reimbursable Costs. For any system that imposes on one party the obligation to reimburse the other party for litigation expenses, whatever the underlying theory or policy, it is an essential requirement of fairness that the costs to be reimbursed be in some way defined and limited. Another reason to control and limit reimbursable costs is the strong commitment of European procedural systems to economy.

There are three principal ways in which reimbursable costs are defined: first, by the general rule that costs and expenses are to be reimbursed only if and to the extent that they were necessary; ${ }^{118}$ second, by enumeration of specific cost items as either reimbursable or not reimbursable; and third, by directly regulating the amounts of certain cost items. Most of the European jurisdictions use a combination of these methods. The details are specified in part in the codes themselves, in part in statutory, official, or semiofficial tariffs or schedules, and in part in case law. They are too varied and too complex to be described fully in this article and the description would not provide much insight. The following overview is limited to some essential points, with emphasis on attorney fees.

The losing party's duty to pay all fees charged by the court or by various court officials is recognized fairly uniformly, but in nature and amount these charges differ from country to country. France abolished court costs almost entirely in December 1977;119 at the other extreme, Spain, Italy, and Austria have still very complex systems of duties, fees, and emoluments of various kinds. ${ }^{120}$ Germany has a statutory fee schedule similar in design to the schedules governing attorney fees. ${ }^{121}$

Most of the countries also provide for reimbursement of attorney fees, although

113. Austria $\S 54(2)$, App. 88.

114. Denmark $\$ 312(2)$, App. 91.

115. France art. 710, App. 103.

116. France arts. 704-708, App. 102-03.

117. Belgium art. 1021, App. 89-90.

118. See supra note 83 .

119. Décret No. 77-1468, of Dec. 30, 1977, 1977 J.O. 6359, 1978 Recueil Dalloz-Sirey, Législation [D.S.L.] 49 .

120. For Spain, see references cited supra note 39. For Italy, see Rubino-Sammatano, Through the Mysteries of Fees in lialy, INT'L BAR J., Nov. 1970, at 8. For Austria, see Fasching, Access to Justice in Austria, in 1 Access to Justice, 205, 207-11 (1978).

121. The rules governing court costs are in the Gerichtskostengesetz, 1975 BGB! I 3047. For attorney fees, see infra note 122 . 
to different extents. In Austria and Germany, where attorney fees are fixed by statutory schedule, ${ }^{122}$ the amount resulting from the application of the schedule is considered a necessary expense and is routinely allowed. ${ }^{123}$ In Switzerland, official fee schedules are common, but courts have traditionally specified the reimbursable expenses at lower amounts. ${ }^{124}$ It appears that only one of the Swiss cantonal procedural codes, that of Geneva, expressly provides for only partial reimbursement of attorney fees. ${ }^{125}$ In a recent case arising under the Zurich code, the Federal (Supreme) Court of Switzerland declared a judgment of the Zurich Court of Appeals, which had assessed the reimbursable attorney fees at an amount below the minimum allowed under the official statute, to be in violation of the federal constitution and void. ${ }^{126}$

France and Belgium present a special situation, due to the fact that both countries traditionally had two major types of legal professionals to assist parties in litigation. ${ }^{127}$ Basically, avoués were required for the preparation and filing of documents in court; avocats acted as advisors on issues of substantive law and as counsel in oral arguments. Avoués were compensated by fees, which were fixed by schedule and recoverable as part of the court costs; avocats received honoraria, which were unregulated and nonreimbursable. In practice, though, the division between the two professions had become more and more obscure over the years, and its justification was increasingly questioned. Eventually, the two professions were merged by legislation that abolished the designation avoue and transferred the functions of the former avoues to the new unified profession of avocat. ${ }^{128}$ This created the problem of how to regulate the remuneration of the new avocats, especially with respect to reimbursement by the losing party. While it was recognized that traditional notions of justice and the interests of the prevailing party argued in favor of full reimbursement of attorney costs, whether in the nature of fees or honoraria, as was the rule in other major European countries, it was perceived as equally important to protect the independence of the legal profession against the threat of regimentation, which, it was feared, would be a consequence of full reimbursement. ${ }^{129}$

122. For Austria, see Schima, supra note 3; for Germany, see Suhr, Legal Fees in Germany, INT'L BAR J., May 1979, at 18, and R. SCHLESINGER, supra note 3, at 351-52.

123. Attorneys and clients may, by express written agreement, set fees at larger amounts than specified in the schedule; in that case, the amount by which the fee exceeds the schedule would not be reimbursable.

124. Attorneys have long complained about this practice. See 1 F. MEILI, Der Zivil- UND STRAFProzess des Kantons ZüriCH UNd des Bundes 105 (1882).

125. Geneva art. 129(g), App. 105; see also Baeck, Imposition of Legal Fees and Disbursements, supra note 3, at 125 ; Habscheid, supra note 65 , at 297-98.

126. Bundesgericht, Apr. 25, 1978, 77 SCHWEIZER ISCHE JUR ISTEN-ZeITUNG 46 (1981).

127. For France, see generally P. Herzoc, Civil Procedure in France 82-89 (1967)

128. In Belgium, this was accomplished in the context of the introduction of the new Code judiciaire of 1967. For France, see 1972 J.O. 5, 1972 D.S.L. 39. The merger in France was not complete but left the position and monopoly of avoués at the appellate courts unaffected.

129. The matter was, of course, discussed extensively, thoroughly, and emotionally. It is impossible to give details. See L'AsSOciation Nationale des Avocats, Au SERVICE de LA JUSTICE: La PROFESSION JURIDIQUE DE DEMAIN 628-47 (1967); Le Maire, L'indemnité de procédure et de debours (pts. 1 \& 2), 1969 Journal des Tribunaux 562, 580; Tang Thi Thanh Trai Le, The French Legal Profession: A Prisoner of Its Glorious Past?, 15 CoRnell INT'L L.J. 63, 74-85 (1982). 
The result of this conflict of policies has been a continuation of a dual system for lawyer remuneration.

The new Belgian code handles the problem by including in the list of reimbursable cost items a provision for compensation for certain attorney services, to be determined in accordance with a schedule promulgated by regulation. ${ }^{130}$ Everyone agrees that the scheduled compensation is not meant to be exhaustive and that the avocats are free to charge additional (nonreimbursable) honoraria. ${ }^{131}$ In France, the existing schedules for avoue fees were simply made applicable to avocats providing the same services. ${ }^{132}$ French lawyers have complained, however, that the schedules have become outdated and that the fees are inadequate, forcing the lawyers to increase their honoraria and to use an increasing part of those (nonreimbursable) honoraria to cover services and costs that according to the intentions of the legislature should be covered by reimbursable fees. ${ }^{133}$

The new French code, while retaining the principle of nonreimbursement for honoraria, allows courts to make an exception whenever they find it inequitable to let one of the parties bear certain expenses not included in the list of reimbursable costs. ${ }^{134}$ The provision is not limited to the honoraria of avocats but applies to expenses of all kinds, including such items as travel and lodging expenses and the cost of procuring evidence. ${ }^{135}$ Under previous law, such expenses had been recoverable when the losing party was at fault. ${ }^{136}$ The broad language of the new provision allows a much more generous reimbursement practice. While there has not been enough time yet for the courts to develop a consistent practice in interpreting the rule, some lower court opinions indicate a tendency to apply it not only in the classic cases of procedural negligence or lack of good faith but also in cases of economic imbalance between parties, such as suits between employers and employees. ${ }^{137}$

In the Netherlands, a legal and formal division still exists between advocaat and procureur, although in practice there has been a complete merger. Fees for both professions are regulated by (separate) schedules promulgated in 1843, which, however, have been found sufficiently flexible to permit periodic adjustment. The procedural code recognizes as reimbursable only the fees of the procureur; the fees of an advocaat are to be reimbursed only to the extent that the total fees do not exceed

130. Belgium arts. 1018(6), 1022; Arrêté Royal of Nov. 30, 1970, Moniteur Belge, Dec. 3, 1970.

131. Le Maire, supra note 129. It would be fair to say that the result in Belgium is a system very similar to that in the United States.

132. 1972 J.O. 5, art. 10, 1972 D.S.L. 39.

133. They have, therefore, demanded legislation to establish a schedule covering not only the routine technical services of the former avoues but also a minimum honorarium. See, for example, the discussion in LE BARREAU DE France, Mai-Juin-Juillet 1978, and the proposal by Jean-Rene Farthouat in LE BARREAU DE FrANCE, Août-Septembre-Octobre 1978, at 6; see also Tang, supra note 129, at 76-77.

134. France art. 700, App. 102. For a detailed analysis, see Loyer-Larher, L'article 700 du nouveau code de procédure civile et le remboursement des frais non compris dans les dépens, 1977 Recueil Dalloz-Sirey, Chronique 205. See also RÉPERTOIRE, supra note 63, 1450.

135. The original version of 1975 referred specifically to "honoraria and other expenses;" the change was made by Décret No. 76-714, of July 29, 1976, 1976 J.O. 4644, art. 5, 1976 D.S.L. 348.

136. See Judgment of Nov. 22, 1932, Cour de cassation (Ch. civile), 1933 Recueil Dalloz Hebdomadaire 2; RÉPERTOIRE, supra note 63, ๆ 441.

137. See Loyer-Larher, supra note 134, at 207-08, and unpublished opinions cited therein. 
the amounts fixed for procureurs. ${ }^{138}$ In present practice, the precise amount to be reimbursed is determined by the court and specified in the judgment; it is usually less than the total amount charged by the attorney. ${ }^{139}$

In England, which also has a functional division in the legal profession, there seems never to have been a doubt that reimbursable costs include the fees of both solicitors and barristers. ${ }^{140}$ The actual amount of the costs to be reimbursed is fixed by special officials, the taxing masters. The courts, however, have the power to select one of several standards by which the taxing master will then evaluate the various cost items.

For instance, the costs to be reimbursed to the prevailing party by the defeated party are normally assessed on a "party and party" basis, defined as including only "necessary and proper" costs. ${ }^{141}$ "The standards used in measuring the costs to be paid to a lawyer from a fund ("common fund" costs) or by his own client ("solicitor and own client" costs) are more generous, including, in the latter case, all costs "not unreasonably incurred." 142

In addition, the taxing officials have established fee schedules for standard matters and services, which, although not binding, provide guidance. ${ }^{143}$ It is unusual for taxing masters to grant the full amount requested. ${ }^{144}$

Attorney fees are recognized as necessary expenses when statutes or court practices require representation by an attorney, or even in the absence of mandatory representation, when it is recognized as customary, reasonable, and proper for a party to employ an attorney. ${ }^{145}$ Conversely, where special jurisdictions or procedures have been established for small claims, in which parties are expected to plead for themselves, the codes often expressly preclude the reimbursement of attorney fees. ${ }^{146}$

In Denmark it was long customary for the courts to fix reimbursable attorney fees at very modest levels and usually lower than those actually incurred. ${ }^{147} \mathrm{Sim}$ ilar complaints have been voiced with respect to Norway ${ }^{148}$ but apparently not

138. Netherlands art. 57, App. 112.

139. For details, see L'Association Nationale Des AvOCATS, supra note 129, at 161-62, 354; Hooftman, Lawyers' Remuneration in the Netherlands, INT'L BAR J., Nov. 1973, at 56-59.

140. Goodhart, supra note 2 , at 856-58.

141. England (b) O.62, r. 28(1), (2), App. 97.

142. England (b) O. 62, r. 29(1), App. 98. There is still considerable confusion about the appropriate reasons for selecting one or the other standard and even about the precise meaning of the different standards. See Cook, Costs-Does the Winner Take All?, LAw Soc'Y GazeTte, Apr. 28, 1982, at 1.

143. The schedules are published as appendices to Order 62 of the Supreme Court Rules. 1 THE Supreme Court Practice 1982, at 1084.

144. For a survey of costs actually charged by solicitors and allowed by taxing masters, see Zander, Costs of Litigation-A Study in the Queens Bench Division, LAW SOC'Y GazETTE, June 25, 1975, at 679.

145. See, e.g., Austria $\S 41(2)$, (3), App. 85; Germany $\S 91(2)$, App. 106.

146. For the English county courts, see Jacob, supra note 103, at 452-53; for the Swedish small claims courts, see Bolding, Access to Justice in Siveden, in 1 ACCESS TO JustiCE 889, 894-97 (1978). For German labor courts, see infra note 156 .

147. See, for example, H. Munch-Petersen, supra note 66 , at 136 , who notes that the revision of 1919 was intended to bring about, among other things, more reasonable reimbursement rates, but did not have that immediate effect in practice. At present, it is estimated that court-ordered reimbursement covers about two-thirds to three-fourths of the fees that the winning party actually has to pay. Letter from Advokat Mikael Rosenmejer (Copenhagen) to Werner Pfennigstorf (July 8, 1983).

148. 5 H. Langendorf, Prozessfïhrung im Ausland und Mängelrüge im ausländischen 
with respect to Sweden. While the Scandinavian countries seem to provide less than full compensation for attorney fees, they are more generous than other countries in reimbursing other expenses of the prevailing party. Notably, the prevailing party can claim compensation for "time and effort expended" on the case. 149 Other systems will, at most, recognize the expense of necessary travel (for example, if the court has ordered the party to appear in person) ${ }^{150}$ but will reject any claim based on loss of time.

In this context it should again be noted that in many cases the prevailing party may have a separate claim for damages, based on tort or breach of contract, under which it can recover for loss of time and other items that are not covered by the procedural cost reimbursement claim. ${ }^{151}$

3. Exclusion of Contingent Fees. The foregoing discussion has shown how much the European codes vary in the ways in which they determine or control attorney fees for reimbursement purposes. On one point, however, there is substantial agreement: Contingent fee agreements of the type commonly used in the United States in personal injury liability cases $^{152}$ are either expressly prohibited or considered unethical. ${ }^{153}$

It is tempting to look for a connection. The acceptance of contingent fees in the United States has been explained by a combination of factors: first, the desire to provide access to the courts to persons who are unable to pay an advance or fixed fee and for whom in fact the unrealized damage claim constitutes the only tangible asset; and second, the relaxation and eventual abandonment of rules against champerty, maintenance, and barratry that had traditionally been interpreted to restrict the practice. American practice, in short, seems to have accepted contingent fees as the preferable alternative to legal aid. ${ }^{154}$ The Europeans, in contrast, seem to have found legal aid the preferable answer and to be less inclined

Recht $\uparrow 6.8 .3$ (loose-leaf edition); Danish and Norwegian Law, A General Survey 205 (Danish Committee on Comparative Law ed. 1963). Sections 176 and 179 were amended in 1973 and are now thought to mean that attorneys always receive the full amount of their fees according to the statement submitted by them to the court, unless the court finds the amount excessive. The latter happens in about ten percent of all cases. Letter from Judge Trygve Lange-Nielsen (Oslo) to Werner Pfennigstorf (Dec. 18, 1982).

149. Norway $\S 176$, App. 115; Sweden ch. 18, § 8, App. 121.

150. Germany $\S 91(1)$, App. 106.

151. See supra note 99.

152. For a description of American-style fees, see F. MACKInNon, Contingent FeEs for LeGal Services: A Study of Professional Economics and Responsibilities (1964).

153. Kalsbach, Introduction/Einfuihrung, 1 LES BARREAUX DANS LE MONDE/DIE RECHTSANWALTSCHAFT IN DER WELT 2, 156-59 (1959) (listing all countries in this report, except Sweden). There are, of course, nuances and qualifications. In Germany the prohibition was established by the courts and the rules of conduct of the legal profession; it was then for a time expressly stated in the law concerning attorney fees, but on occasion of a recent revision (in 1957) it was eliminated again from the law to allow the courts to recognize exceptions. See R. SCHLESINGER, supra note 3, at 653-60. The rules of conduct provide that agreements making the amount of the fee dependent on the success of the attorney's activity may be permissible in (unspecified) exceptional cases, provided they do not impair the attorney's independence; agreements under which the client promises the attorney a percentage of the proceeds of the case are prohibited without exception. See Grundsätze des anwaltlichen Standesrechts $§ 52$ (1977); F. KUNIGK, DAS ANIVALTSHONORAR 27 (1978).

154. F. MACKINNON, supra note 152, at 209-11. 
to abandon traditional ethical concerns regarding contingent fees. ${ }^{155}$

To what extent the difference in cost allocation rules has contributed to this development is a question to which empirical answers are difficult to find. It can be speculated, however, that the conditions for acceptance of contingent fees may have been somewhat more favorable in the United States because, under the American rule, a claimant only had to worry about his own costs, and the contingent fee offered an answer, win or lose. A European claimant, in contrast, also has to worry that if he loses he will have to reimburse the defendant, and for that contingency the contingent fee arrangement does not have an answer.

Other factors may explain why there has been less pressure to introduce or tolerate contingent fees: fewer claims, lower amounts, trials without jury, and recognition of subrogation in favor of social security carriers in personal injury cases. It is difficult to say to what extent each of these is responsible for the absence of contingent fees or to what extent each is influenced by the presence or absence of contingent fee agreements. ${ }^{156}$

One could point out that Europeans, in contrast to Americans, developed legal expense insurance early, which solves the claimant's problems better than the contingent fee, not only by paying his own attorney without diminishing the amount of damages actually received by the claimant, but also by paying the costs due the opponent in the event of defeat. ${ }^{157}$

Finally, and perhaps most importantly, while the European jurisdictions are uniform and adamant in rejecting the concept of contingent fees, in at least some of them the existing rules concerning the determination of attorney fees produce results that are in many respects very similar to those of a contingent fee agreement, especially if one looks at the situation of a low-income claimant.

First, the most important criterion for establishing attorney fees in litigated cases in many of the European countries is the amount in controversy. The amount of work actually performed is rarely considered. Thus, the fee of an attorney representing a personal injury claimant in Germany becomes larger as the amount of the judgment increases. If the award is small, the lawyer's fee is also small, regardless of the number of hours he has spent on the case.

Second, while an unsuccessful claimant in Germany, for example, is legally obligated to pay his lawyer's fees (and the costs of the defendant), the lawyer violates no law and no ethical rules if he refrains from collecting the fees, especially from a client who is an individual of limited means. German lawyers may require an advance before accepting a case, but they need not do so.

155. See infra text accompanying note 163 .

156. In the limited context of this discussion, the author hopes he will be excused from furnishing full documentation for all the statements contained in this paragraph.

157. For details, see Pfennigstorf, The European Experience in Legal Expense Insurance, in LEGAL SERVICE Plans: Approaches to Regulation 487 (1977) [hereinafter cited as Legal Service Plans]. An American litigant is to some extent protected against litigation costs by liability insurance--if the litigation concerns a damage claim, if he is the defendant, if he is covered by liability insurance, and if the amount of the liability insurance is adequate. Liability insurance does not help plaintiffs, and contingent fee arrangements help only those who have damage claims for substantial amounts. Everyone else will have to pay a retainer fee to obtain representation by a lawyer. 
The result is, from the perspective of the attorney, not much different from that of an American-style contingent fee agreement. From the perspective of the client, of course, there is an important difference: If the court decides in his favor, he receives $100 \%$ of the amount of damages awarded by the court, the fees of his attorney being paid by the defendant. If the court rejects his claim, he faces legal obligations both to his own attorney and to the victorious defendant.

\section{Special Rules for Special Matters or Jurisdictions}

The case of the no-fault divorce, mentioned as one of the recognized exceptions to the general rule on cost reimbursement, ${ }^{158}$ can also serve as a fitting introduction to this section, which deals with classes of cases or whole areas of law for which strict application of the traditional rule has been found unsuitable or, stated positively, for which it has been possible to give general form and application to some of the considerations of equity that ordinarily find expression only in the context of isolated individual cases.

1. Mandatory No-Fault Court Proceedings. In the case of a no-fault divorce there is no basis for a presumption of fault. The defendant in such a case cannot be charged with having pursued or defended an unfounded legal position; he or she becomes involved only because the plaintiff pursues an objective that is expressly permitted by the law and that can be reached only through formal court proceedings. In short, in these proceedings the defendant is not an active participant or adversary but rather (though not always) an innocent victim. The defendant must suffer the legal effects of the proceedings, but it would be unfair to burden him or her also with the costs incurred by the plaintiff. A general exception to the rule for all cases of this type is therefore justified.

There are other similar situations. The German civil code protects tenants of apartments against one-sided termination of the rental agreement not only by limiting the grounds on which the landlord can base a termination but also by prescribing elaborate procedures that may result in litigation. In proceedings of this kind it is especially important to discourage the parties from holding back relevant facts or arguments. Consequently, as a special implementation of the general principle of procedural economy, the code of civil procedure permits imposition of costs on the prevailing party if timely notice or knowledge of material facts would have made the proceedings unnecessary. ${ }^{159}$

2. Social and Economic Imbalance. Landlord-tenant cases are also representative of a different class of special situations-those in which typically one party's economic power and social standing give it a natural superiority and advantage over the other. The need to protect the weaker party in such situations was recognized first in labor relations, later in social security matters, and most recently in administrative law matters generally, where the individual faces the power of the government, especially in the'field of taxation.

158. See supra notes 103-105 and accompanying text.

159. Germany §93b, App. 108. 
In these situations, the cost risk affects the two parties unevenly. Lessening the risk is one of the many measures that have been taken to even the natural imbalance. Other measures include a general lessening of the incidence of costs, for instance, by eliminating the requirement of representation by attorneys, by admitting nonlawyers as representatives, by encouraging mediation and settlements, and by general simplification of procedures. In many countries, special courts with their own special procedural rules have been established for these matters. ${ }^{160}$ Even when they are handled by the general courts under the general rules, adjustments are sometimes made with respect to cost allocation. Thus, the new Belgian code of 1967 was amended in 1971 to provide that in any litigation between carriers and beneficiaries of social security or social welfare programs, the carrier is always to be ordered to bear the costs. ${ }^{161}$ This means that if the claim of a beneficiary is eventually rejected (except frivolous or vexatious claims, which are expressly excluded), the carrier not only cannot recover its expenses but must, in addition, reimburse the unsuccessful claimant for his expenses.

Few of the other systems are equally generous. Germany, for instance, has special court systems, each with its own special procedural rules, for labor matters, for'social security and welfare matters, for taxation matters, and for matters involving administrative law generally. The most that these rules do for the individual with respect to costs in the event of losing, however, is to require no payment of court costs and to require no reimbursement of the costs incurred by the government, carrier, or employer. ${ }^{162}$ The Italian code no longer exempts workers from the cost reimbursement burden in labor matters. ${ }^{163}$ Workers who unsuccessfully pursue social security benefits, however, need not reimburse the social security carrier except when the claim is unfounded and frivolous. ${ }^{164}$ In Swedish labor matters the court may relieve the losing party of cost reimbursement if that party had reasonable grounds for litigating the case. ${ }^{165}$

160. These efforts are, of course, part of the larger movement to give everyone access to justice. See supra note 5 .

161. Belgium art. 1017(2), App. 89 (added by law of June 30, 1971).

162. In the labor courts, neither party can demand reimbursement for attorney fees at the trial court level -a measure designed to discourage representation by lawyers. Appeal procedures follow the general rule. Arbeitsgerichtsgesetz $\S 12 a, 1979$ BGBl I 853, corrected 1036. In the tax courts, only the successful taxpayer can claim reimbursement of attorney fees; the government has no such right. Finanzgerichtsordnung $\S 139(2), 1965 \mathrm{BGB}$ I 1477. In the social security courts, the government or carrier may never claim reimbursement. With respect to the beneficiary's or participant's legal expenses, the court has discretion to order reimbursement in full or in part, or to deny it, according to the circumstances. Sozialgerichtsgesetz $\S 193(1), 1975 \mathrm{BGBl}$ I 2535. In the general administrative courts, the rules with respect to costs are the same as for civil courts. Verwaltungsgerichtsordnung $\S 154(1), \mathrm{BGB} 1960$ I 17 . But because representation by attorneys is not mandatory before the lower administrative courts and the government is usually representated by civil service lawyers, the losing citizen rarely has to reimburse the government for attorney fees.

163. See Vigoriti, Access to Justice in Italy, in 2 Access TO Justice, 649, 660 (1979). In 1973, a law establishing the new procedures for labor matters repealed art. 449 of the Italian code, which had excluded reimbursement of attorney fees in labor cases involving amounts under 2,000 lire and had given the court discretion to order or deny reimbursement in cases involving larger amounts.

164. Disposizioni per l'attuazione del codice di procedura civile e disposizioni transitorie, Regio Decreto of Dec. 18, 1941, No. 1368, art. 152.

165. Bolding, supra note 146 , at 902 . This provision, in fact, restores for labor matters the rule that had been in effect generally for all cases prior to the revision of 1948 . 
3. Sovereign Immunity. While the special rules for labor and social welfare matters recognize the individual citizen's need for protection in his dealings with the government, there is also a vast range of powers and privileges that have traditionally been associated with the government as the sovereign, and which have not been eliminated everywhere concurrently with the advance of citizens' rights. In France, for example, it is established case law that neither the national government nor a regional or local government unit is ever ordered to bear the costs upon losing in litigation with private parties. ${ }^{166}$

4. Differentiation in Fee Standards. One noteworthy alternative to direct cost shifting has been employed in Germany in cases characterized both by large amounts and by economic imbalance among the parties: infringement of patents, trademarks, or utility models; violations of fair trade standards; and actions by minority shareholders contesting the validity of a stockholders' resolution. Since in Germany the amount of court fees and attorney fees is determined primarily by the amount at issue, large values always mean large fees, even for poor parties and even if the case requires only little and simple legal work. To make sure that parties of limited resources are not excluded from the courts by the risk of prohibitive fees, the German laws authorize the courts, in these special cases, to fix the value of the case, so far as it is relevant for fee determination, at a lower amount for one party than for the other. ${ }^{167}$ The result of such an order is an indirect shifting of the cost burden. Initially, the attorney of the rich party becomes entitled to fees measured on the basis of a larger amount (determined according to what the case is worth to the rich party), while the attorney of the poor party becomes entitled to fees measured on the basis of a smaller amount (determined not according to what the case is worth to the poor party but acording to what the poor party can afford to pay). If the poor party loses, its obligation to pay the entire court costs and to reimburse the victorious rich party is measured by the smaller amount, leaving a portion of the rich party's attorney fees unreimbursed.

166. For references, see RÉPERTOIRE, supra note 63, ๆ $369-75$. In assessing the effect of this rule, one has to remember that attorney fees are generally unreimbursable.

167. For patent infringement cases, the rule has been in effect since the enactment of the Patent Act in 1937. It was $\S 53$ of the 1937 Act but it is now $\S 144(2)$ of the revised version promulgated December 16 1980, BGBI 1981 I 1. It reads as follows:

(1) If in a patent dispute one party shows that imposition of litigation costs based on the full value of the case would seriously endanger its economic situation, the court may, on its request, order that party's obligation to pay court fees to be measured on the basis of a portion of the value adapted to its economic situation. As a further effect of the order, the favored party has to pay fees to its attorney on the basis of the portion of the value. Insofar as litigation costs are imposed on or assumed by the favored party, it has to reimburse the court fees and attorney fees of the opponent only on the basis of the portion of the value of the case. Insofar as out-of-court costs are imposed on or assumed by the opponent, the favored party's attorney may collect from the opponent fees on the basis of the value applicable to the latter.

The corresponding, almost identical provisions in the other laws were added later in response to public complaints about large corporations or industry groups using the threat of large fee reimbursement claims to suppress criticism and legitimate complaints. See infra text accompanying note 209. The law of July 21 , 1965, 1965 BGB। I 625, added § 23a to the Fair Trade Practices Act (Gesetz gegen den unlauteren Wettbewerb, of June 7, 1909, 1909 RGBI S. 499), § 31 a to the Trade Mark Act (Warenzeichengesetz 1968 BGBl I 29), and $\S 17$ a to the Utility Model Act (Gebrauchsmustergesetz), 1968 BGBI I 24). The Stock Corporation Act was amended by adding $\S 247(2), 1965$ BGBI I 1089. 
If, on the other hand, the poor party succeeds, the larger amount fixed for the rich party governs not only the court costs that it has to pay but also the reimbursement due the poor party. There is thus a certain superficial similarity between this fee differentiation and a contingent fee arrangement except that in the event the poor party loses, his attorney is entitled to the lower fee rather than being left with nothing, and that in the event of success, the fee is paid by the defeated opponent and does not diminish the amount recovered.

\section{E. Cost Allocation and Legal Aid}

This article and symposium are not about legal aid, which is a separate and very complex subject. ${ }^{168}$ Yet, it is obvious that cost allocation rules and legal aid rules influence each other. When a litigant can expect to recoup his expenses upon successful completion of the case, it would seem that all that is needed to assure access to justice is to defer payment of court costs and attorney fees, to screen out all the cases that do not have a reasonable chance of success, and then to wait for the court to rule in the poor party's favor and impose all costs on the opponent. Traditionally, most European legal aid programs were indeed based on this premise. It was, of course, not possible in all cases to predict accurately the decision of the court, and there were other cases in which the poor party did not obtain full reimbursement, especially in settlements where costs were split. Modern legal aid systems tend to be more generous, especially in giving the benefit of the doubt to those seeking access to the courts. This more liberal policy increases the number of cases where parties who are supported by legal aid end up losers and consequently not only get nothing from the opponent but also are obligated under the general rules to pay court costs, their own attorneys, and the opposing party's costs, while being unable to do so. It seems reasonable for a legal aid system to accept the risk that a certain percentage of aid recipients lose their cases and the amounts expended in supporting their causes; it is an entirely different question whether the opposing prevailing party can be expected to accept without complaint and without compensation the loss of its reimbursement claim.

It is true, of course, that the law, and especially the rules of civil procedure, do not guarantee that a party ordered by a court to pay a certain amount actually has the means to pay it. This is a risk that the parties traditionally have had to assume themselves, at least when they were plaintiffs. The defendant, however, sometimes has the right to demand that the plaintiff make a security deposit for litigation expenses that he would have to reimburse to the defendant in the event of dismissal. ${ }^{169}$ When such rules are applicable, logic would require either that the legal aid office put up the security or that the defendant's reimbursement claim be secured in some other way.

168. For a comparative survey, see especially M. CAPpelletti, J. GORdley \& E. JOHnSON, JR., Toward Equal Justice: A Comparative Study of Legal aid in Modern Societies (1975).

169. Provisions like this are standard for foreign plaintiffs. For Germany, see ZPO $\S 110,1950$ BGB। S. 533; for Norway, see Law on Judicial Procedure in Civil Cases (Norwegian Laws, loose-leaf, 1980), $\S 182$. A provision in the Italian code, applicable to all plaintiffs (codice di procedura civile, Regio decreto 28 ottobre 1940, No 1443, art. 98), was declared unconstitutional and void in 1960; Corte Costituzionale, Nov. 29, 1960, No. 67, 5 Giur. Cost. 1195 (1960). 
The English legal aid law authorizes the court to determine the amount to be paid by the losing legal aid-assisted party in taking the economic circumstances of both parties into account; it even authorizes the court to order an additional payment to the prevailing party out of the legal aid fund if that is necessary to prevent hardship to that party. ${ }^{170}$ German legal aid rules, revised in 1980, still leave both the victorious opponent and the unsuccessful legal aid recipient to their own resources with respect to reimbursement, ${ }^{171}$ even though the security requirement need not be met. ${ }^{172}$

If the assisted party is successful, it seems to be recognized everywhere that he can demand reimbursement for attorney fees in the full amount that the attorney could have charged an unassisted party, not just the amount provided by legal aid. ${ }^{173}$ Again, one is reminded of American contingent fees, but the situation is different both with respect to the attorney, who in the event of defeat receives at least the legal aid fee, rather than nothing, and with respect to the prevailing plaintiff, who receives $100 \%$ of the judgment amount and does not have to share it with his attorney.

\section{IV}

\section{Theoretical Justifications and Political Explanations}

\section{A. Overview}

As a mature institution, evolved over a time span of more than 1500 years, fee shifting cannot be expected to be simple either in theoretical foundation or in practical application. Rather, the picture that has emerged from the summary of existing rules and practices in the preceding sections is one of confusing variety and complexity; as is to be expected, it reflects the compromises, adjustments, and differentiations that have become necessary over the years as each legal system, in its own context of broader cultural traditions, attitudes, and customs, has struggled to accommodate competing and often incompatible policies.

Complex and contradictory as the theories behind the European rules may be, they deserve a closer look, both in view of the general purpose of this symposium and in view of Professor Rowe's recent discussion of potential rationales for fee shifting in the United States and other common law jurisdictions. ${ }^{174}$ Rowe identifies six such rationales: promoting fairness, making a litigant whole for a legal wrong suffered, punishing a litigant for wrongdoing, encouraging litigation considered useful for the public (the "private attorney general" concept), rectifying large disparities of strength of the parties, creating economic inducements for certain

170. Legal Aid Act, 1974, ch. 4, §§ 13, 14; Legal Aid (General) Regulations, 1980, STAT. Inst. Pt. III, No. 1894, rr. 127-140.

171. ZPO $\S 123$, as revised by Prozesskostenhilfegesetz (litigation cost aid law) of June 30, 1980, 1980 BGBI I 677 .

172. Germany $\S 122(1)$, no. 2 .

173. Under most codes, the attorney of the prevailing legal aid party can demand payment of the full fee directly from the defeated party. See, e.g., ZPO $\$ 126,1950$ BGBI S. 533.

174. Rowe, The Legal Theory of Altomey Fee Shifting: A Critical Overview, 1982 DuKE L.J. 651. 
desirable litigation behavior. Most of these ideas have also been recognized in Europe, with the exception of the private attorney general concept.

Theories, however, form only part of the background of the existing pattern of cost allocation rules. Understanding the theories, even agreeing upon them, does not help much in understanding why various countries have adopted different rules or qualified the same basic rule by different exceptions. In this section, therefore, an attempt is made to cast some light on the attitudes and sentiments that may be responsible for the political choices that have been made. In addition, a few words need to be said about indirect or secondary conflicts-forces that are directed not against the idea of fee shifting as such but against some of the consequences of its implementation, such as the establishment of standards or schedules for attorney fees.

\section{B. Theories}

True to the traditions of European legal scholarship, much serious thought has been devoted to the theoretical basis for imposing litigation costs on the defeated party. A rich literature has developed, which cannot be related here in full detail. ${ }^{175}$

It should be enough to state that at one time or another almost all of the theories on Professor Rowe's list have been advanced in one country or another. Historically, as noted, punishment and deterrence of abuse of the judicial system by unfounded, frivolous, or vexatious actions were primary motives. ${ }^{176}$ Later the general principles of liability for damages were carried over to the special procedural relationship between litigants. ${ }^{177}$ While punitive ideas originally and primarily focused on the prelitigation conduct of the parties, that is, the decision to pursue or to resist a claim, some of the present European codes also make use of the power to impose costs to enforce standards of expediency, economy, cooperation, and good faith in the course of litigation. When this is done, it constitutes an exception to the general rule that imposes the costs on the defeated party.

The theory that now seems to be most popular in Europe has some similarity with what Professor Rowe calls the "make-whole" rationale. ${ }^{178}$ It is not, however, as rigidly tied to the classic concept of retributive justice, since it does not presuppose a legal wrong and its effect is not limited to a return of unlawful gain. Rather, the idea that this principle, sometimes referred to as the "net-of-cost" principle or "full-value" principle, expresses is that a claimant who is forced to resort to court action to enforce his claim againt a reluctant debtor is entitled to recover the full value of the claim and should not be expected to be satisfied with a lesser amount because of the necessity of suing. Likewise, one who successfully defends himself against an unjustified claim raised by another person should come out of

175. For a recent summary and bibliography, see Vecchione, supra note 6.

176. See W. ENDEMANN, supra note 22, at 505-06.

177. Id. This theory is still the prevailing one in Spain, although it has been challenged and is about to be abandoned. See supra notes $36-42$ and accompanying text.

178. Rowe, supra note 174 , at $657-59$. 
the experience without financial loss. This view has long been stressed in Italy ${ }^{179}$ and in France ${ }^{180}$ and also recently has been cited with approval in Germany. ${ }^{181}$

The punishment theory can justify imposition of costs only on a litigant who can somehow be blamed for coming into court with a losing case; the damage theory suffers from the same weakness if it follows the negligence model. When the rule is based on a theory of no-fault liability for causation (objective liability), ${ }^{182}$ or on the idea of deterrence, it is. somewhat easier to defend, but it does raise questions about the fairness of its effects on "innocent" bona fide litigants.

The net-of-cost principle is not quite as limited in its reach as it focuses on the situation of the prevailing party, for whom, of course, it does not make any difference whether the opponent acted in good faith or in bad faith. Still, in cases involving good faith mutual disagreement, where the outcome is difficult to predict, the argument in favor of giving the victor all net of cost at the expense of the loser loses much of its persuasive force.

No one, consequently, seems to be fully satisfied with these theories or to rely on them exclusively. Rather, alternative explanations are offered, some of them of a positivistic nature.

It has been said that the obligation to bear litigation costs is a corollary of giving every one unrestricted access to the courts for the purpose of pursuing alleged rights against other persons. ${ }^{183}$ In a similar vein, it has been suggested that the obligation results from the special relationship into which litigants enter and that they must be deemed to have agreed to the consequences that the law provides. ${ }^{184}$ Others have dismissed the need for any theory and instead declared the cost obligation a creation of legislation, which itself constitutes sufficient justification. ${ }^{185}$

One of the most thoughtful commentators has argued that the cost allocation rules must be analyzed in the context of the complex system of civil procedure and are entirely subject to the policies that shape that system. ${ }^{186}$

In a broader sense, the imposition of costs on the defeated party has been referred to as "natural." 187 It has even been said to have become, over the ceniuries, so much a part of popular perceptions of the law and legal procedures that it

179. See, e.g., V. ANDRIOLI, supra note 74; Vecchione, supra note 6, at 1124-25.

180. L'AsSOciation Nationale des AvoCATS, supra note 129; Le Maire, supra note 129.

181. See Grunsky, Empfehlen sich im Interesse einer effektiven Rechtsverwirklichung für alle Bürger Änderungen des Systems des Kosten- und Gebührenrechts?, in 1 VERHANDLUNGEN DES EINUNDFÜNFZIGSTEN DEUTSCHEN Juristentages A67 (1976); Pawlowski, Zur Funktion der Prozesskosten, 1975 JURISTenzeItung 197, 202; Schima, supra note 3.

182. For an elaborate statement of this theory, see Görres, Die Haftung für den Ersatz von Kosten and Schäden nach deutschem Prozessrechte, 35 ZEITSCHRIFT Für DEUTSCHEN ZIVILPROZESS 313 (1906), with references to parallel developments in the area of civil liability for damages, which Görres attributes to the Germanic (as opposed to Roman law) roots of German law.

183. See Baumbach-Lauterbach, ZPO, 40. Auflage, Übersicht vor $\S 91$ (1982).

184. Id.; W. ENDEMANN, supra note 22, at 507-08.

185. W. ENDEMANN, supra note 22, at 508. This argument was proposed in the middle of the nineteenth century when codified law had just started to replace the customary principles derived from Roman law.

186. F. Klein, Der Zivilprozess ÖSTERREICHS $159-60$ (1927 \& reprint 1970).

187. W. ENDEMANN, supra note 22, at 506. 
no longer needs to be justified on ulterior grounds, the long period of practice and acceptance itself providing sufficient justification. ${ }^{188}$

No claim is made that the principle commands universal application; the German Federal Constitutional Court, for instance, considered and generally accepted it but refused to grant it the rank and authority of a constitutional principle. ${ }^{189}$

This is a remarkable paradox-a principle that is almost universally recognized in European jurisdictions, formally announced in codes, supported by longstanding custom and public opinion, and yet not capable of being satisfactorily justified in terms of legal theory. ${ }^{190}$ It seems to require explanation on a different level, that of sentiments or attitudes, which are difficult to incorporate into legal theory.

\section{Sentiments and Attitudes}

It becomes apparent that factors of a psychological nature are involved when one contrasts the European reliance on custom and nature with the claim on the other side of the Atlantic that the American rule is grounded on the idea of fairness. The same conclusion is suggested by the strong emotional reactions that Europeans display when confronted with the American rule. ${ }^{191}$ Yet, the sentiments and attitudes that are active here are rarely discussed. All one encounters in the literature are occasional inferences.

The line of thinking that eventually leads to psychological factors starts with the realization that costs are generally an unwelcome element, an evil that unfortunately is an unavoidable by-product of litigation. Traditionally, only three options were available for dealing with costs: letting each party always bear its own, imposing them always on the defeated party, and imposing them on the defeated party under certain circumstances. The third option has always been regarded as the most appealing one but has presented two serious difficulties.

First, while it is easy to agree that costs should be imposed on the party who litigates in bad faith or somehow abuses the judicial system but should be borne by each party for itself in cases involving legitimate doubt or disagreement, it is very difficult to establish generally applicable criteria by which it can be determined whether a given case belongs in one or the other class. The problems are compounded by the ambivalent attitude that almost everyone has toward litigation.

188. For references, see Bokelmann, 'Rechtswegsperre' durch Prozesskosten, 1973 ZEITSCHRIFT FÜR RECHTSPOLITIK 164, 169. The discussion and reform proposals reported here did not produce any change in this attitude. See infra text accompanying notes 206-226. Even in 1977, after the issue of costs had been discussed in the literature for several years, a commission charged with making recommendations for a revision of the code of civil procedure did not consider it necessary to devote more than two pages to it. Following a half-page summary of the rules of other countries, the commission recommended retention of the winner-take-all rule "because it has proven useful in German civil procedure." BERICHT DER KOMMISSION FÜR DAS ZIVILPROZESSRECH'T 225 (1977) [hereinafter cited as KOMMISSION].

189. 14 Entscheidungen des Bundesverfassungsgerichts 42 (1962)

190. It is perhaps no accident that the theoretical underpinnings of the American rule are not much stronger. See Leubsdorf, Toward a History of the American Rule on Attorney Fee Recovery, LAW \& CONTEMP. PROBS., Winter 1984, at 9.

191. See Ehrenzweig, supra note 3 . The author of this article admits to similar reactions. 
Certain types of cases should not be litigated and should be discouraged; other types deserve to be encouraged. Which is which often depends on the context in which the question is asked, in addition to general perceptions of the function of the courts and their role in dispute settlement or enforcement of rights.

The conflicts and contradictions arising when the goal of better access to the courts is pursued at the same time and with equal fervor as the search for alternative forms of dispute resolution are necessarily reflected in discussions of how to allocate litigation costs. Attitudes may even be affected by special sympathy for certain litigants (environmental groups, minorities) or certain causes (consumer complaints) as compared to others.

Second, to the extent that cases in which cost shifting is justified can be identified by reference to the state of mind of a party, it is difficult to ascertain whether the requisite state of mind is present. If this subjective element can be ascertained at all, it can only be done by the court, after the case has been decided.

This presents new problems. In Spain, where costs generally are imposed only in cases of bad faith litigation, the experience has been that judges are reluctant to make such findings. ${ }^{192}$ There are indications that American courts are equally reluctant. ${ }^{193}$ Cases in which parties are ordered to reimburse their opponent's costs and expenses seem to be rare.

If standards were lowered and courts given discretion to distribute costs on a case-by-case basis depending on whether in their view one or both of the parties had reasonable grounds to let the case proceed to court, the result could be the addition of another issue to delay and complicate the disposition of the case. The system seems to work reasonably well in Norway ${ }^{194}$ and Denmark, ${ }^{195}$ but was considered unsuitable for Germany in the middle of the nineteenth century. ${ }^{196}$

In addition to concerns about adding fuel to the fire, there are concerns about uncertainty and unpredictability of judicial decisions, given the lack of binding or persuasive objective criteria. ${ }^{197}$ Those concerns were especially strong during the nineteenth century as part of the general movement away from the theories and practices of Roman law as they had been passed on and modified over the centuries, toward codifications that were supposed to rest on clear and simple principles of natural law. Proponents of codification did not favor leaving issues to judicial discretion or even interpretation. ${ }^{198}$ In the permanent philosophical struggle between certainty and predictability on one side and equity on the other side, the

192. See supra note 39 .

193. See Mallor, Punitive Attomeys' Fees for Abuses of the Judicial System, 61 N.C.L. REV. 613,639 (1983).

194. As in the other countries, there are no statistics showing the proportion of cases in which costs are imposed on one of the parties. According to an informed estimate, the ratio is about one-half at the circuit court level. Letter from Judge Trygve Lange-Nielsen to Werner Pfennigstorf (Dec. 18, 1982).

195. Here, too, statistics are not available. It is estimated that the courts deviate from the rule in about $10 \%$ of all cases because of special circumstances, most frequently when the government is the prevailing party.

196. W. ENDEMANN, supta note 22, at 508-09.

197. G. Baumgärtel, Gleicher ZuGang ZUM Rfcht für alle: Ein Grundproblem des RECHTSSCHUTZES 153 (1976); W. ENDEMANN, supra note 22, at 509 nn.22-23; Bokelmann, supra note 188, at $164,168-69$.

198. On the philosophy of codification, see Pound, Sources and Form of Law, 22 Notre DAME LAW. 1 (1946). 
balance had definitely shifted in favor of certainty at the time when the major procedural codes of the nineteenth century were conceived. This is probably the single most persuasive explanation for the rigid position adopted by some of the nineteenth century codes.

The persuasive force of the Roman law tradition partially explains why the drafters of the codes, in removing judicial discretion with its inherent uncertainty, decided in favor of letting the costs fall on the defeated party rather than letting each party bear its own. All that had to be changed was to make the traditional presumption of temerity irrebuttable. This is not, however, the only factor.

When it cannot be determined objectively whether a litigant had reasonable grounds for asserting or contesting a right in court, and when there are concerns about letting judges decide case by case, without clearly defined standards, who is to bear the costs, there remains only one basis for differentiation: the judgment that puts an end to the principal issue. ${ }^{199}$ It is the whole and sole purpose of civil litigation to find out, and to make known conclusively by judgment, who is right and who is wrong. A judgment does not retroactively change a good faith dispute into a bad faith dispute, but its very existence and inherent authority do create a new situation and inevitably affect the outlook of both participants and outsiders, and not only with respect to the narrow substantive issue decided. This effect is not prescribed by code or supported by legal theory, ${ }^{200}$ but it is a psychological reality nevertheless.

In support of the American rule, reference has been made to the chance that courts can err, reflecting the traditional American sympathy for the underdog. To this, Goodhart has the following answer: "If New Jersey justice is so much a matter of luck, it seems hardly worthwhile to have courts and lawyers; it would be cheaper, and certainly less dilatory, to spin a coin."'201

This also fairly expresses European sentiment: To every dispute, there must be an end, and the judgment of the court on the principal issue is generally accepted as sufficient authority to carry the cost decision as well.

In this context, it has even been suggested that the ancient notion of a wager, which, as noted, was evident in some early forms of Roman procedure, is still alive in popular perceptions of litigation. ${ }^{202}$ Equally strong as an indicator of popular perceptions is the use of words suggestive of warfare that one finds frequently in discussions of litigation. Both the wager and the battle analogies would explain general acceptance as "natural" of a rule under which "the winner takes all."

\section{Implications of Implementation}

It has already been noted that even after the issue of judicial discretion as to

199. This connection has been suggested most clearly by Klein. F. KLEIN, supra note 186, at 160

200. See G. BAUMGÄRTEL, supra note 197. It seems fair to say, however, that the same attitudes and sentiments that are at the base of the legal doctrines of the authority of judgment are also likely to have an influence on perceptions concerning proper allocation of costs.

201. Goodhart, supra note 2, at 877 (responding to Satterthwaite, Increasing Costs to be Paid by Losing Party, 46 N.J.L.J. 133 (1923)).

202. F. KLEIN, supra note 186; Bokelmann, supra note 188 , at 168. 
good faith losers has been disposed of, the variety of situations is great enough to ma:se implementation of a fee shifting rule a complex and difficult problem. Especially when judicial discretion cannot be relied on to achieve equity in individual cases, it is necessary to modify the general rule to produce equitable results or to prevent hardship in special situations. This need and the various methods that have been used to meet it have become apparent in the discussion of existing rules.

What needs to be shown here is that implementation of a cost allocation rule following the European tradition is subject to its own inherent pressures that determine how it is eventually applied. ${ }^{203}$ This can be illustrated by looking at three special aspects of implementation.

1. Need to Differentiate. Not only do some procedural situations present special problems of equity, as in the case of no-fault divorces, but there are also whole areas of the law that bring with them strong public policies favoring one party over the other or encouraging or discouraging certain aspects of litigation. In Europe it is the labor courts or labor matters, and in the United States it is such areas as civil rights and environmental protection that have required special treatment.

2. Need to Accommodate General Policies of Civil Procedure. Once a system of cost allocation is in place, on whatever theoretical, political, or legislative basis, it inevitably becomes subject to other policies that are not relevant to the basic decision on which party should bear the costs. Thus the power of the courts to impose costs has been found to be a convenient tool for achieving such general and unrelated goals as procedural economy, expendiency, and honesty in the course of litigation. Demands have also been made on the cost system to further the cause of equal access to justice.

3. Need to Control Costs. One of the most important problems in implementing a European style cost allocation system is the need to control costs to the extent that they are to be reimbursed. It is true, as Professor Rowe has pointed out, ${ }^{204}$ that we need not be too concerned about the amount of reimbursable costs as long as they are imposed for the purpose of punishing a party for litigating in bad faith or for some other blameworthy conduct. When, however, as in most European countries, costs are imposed without regard to bad faith or temerity, it becomes a requirement of elementary fairness to protect the defeated party against reimbursement claims for extravagant and unnecessary measures, exaggerated fees, or unverified expenses.

Controls are needed both with respect to the necessity of a specific act, or motion, or service obtained and with respect to the amount of the fee or price incurred therefor. The control mechanism can involve statutory standards or fee schedules, evaluation by the court, or some outside evaluation.

Repercussions from control mechanisms can be extensive, not only for attor-

203. This was pointed out by Rowe, supra note 174 , at $666-78$

204. Id. at $676-78$. 
neys, who may see their professional independence threatened, but also and perhaps even more significantly for the role of the court in monitoring the progress of a case, and thus some of the basic structural principles of civil procedure. Some of these implications should have become apparent in the previous description of the various systems.

\section{E. Counterforces}

Each of the various aspects of implementation can generate forces that, while directly related only to that particular implementation measure, can have a wider indirect effect on the basic rules of cost allocation. As an example, it will be shown in the next section, on reform proposals, how concern about equal access to justice can lead to challenges of the entire cost system.

Another powerful counterforce results from the spirit of independence of the legal profession, which in some degree has existed everywhere and always, but has manifested itself in different forms in different jurisdictions and, in particular, has produced different reactions to the idea of cost allocation and the concomitant efforts to control costs. There is hardly any jurisdiction where lawyers have been always and completely happy with the ways in which courts or legislatures have tried to control their remuneration. Usually, however, the profession has found it possible to have its position and interests considered and to achieve a workable solution that provides an acceptable degree of control while not placing unreasonable strains on its professional independence.

In Belgium and France, the legal profession, while generally accepting the principle of full cost fee shifting, so abhors the prospect of the consequent regulation of remuneration as an intolerable incursion into professional independence that it not only concluded that the interests of clients must take second place, but also succeeded in persuading the legislature to rule accordingly. Among European jurisdictions, however, this is the exception from the rule.

In this context, the origin of the American rule, as it has been traced most recently by John Leubsdorf for this symposium, ${ }^{205}$ appears as an even more striking case where absence of controls over lawyer remuneration (whether due to reluctance on the part of the courts or legislatures to impose and enforce such controls or to resistance on the part of the legal profession) has had the result of eroding an existing cost shifting system and of preventing the introduction of a new one.

This is not meant to suggest that the profession's interest in preserving the freedom of lawyers to determine their remuneration was the only factor, or even the principal factor, in the acceptance and retention of the American rule. In view of what little is known about its development, however, the parallel is too obvious to be ignored.

205. Leubsdorf, supra note 190. 


\section{V}

\section{REFORM PROPOSALS}

If some scholars, while generally supporting the European rule, appear to be somewhat uncomfortable, the reasons must be sought not so much in the allocation rule itself but rather in a sense of frustration over the fact that there are costs to begin with and that they must somehow be allocated to one or both of the parties. There is hardly anyone who would not prefer that justice be completely free. As long as that is not considered feasible, and costs must be accepted as a necessary evil, replacing one allocation rule with another only shifts the cost burden and the resulting hardship from one party to the other.

Consequently, to the extent that the allocation of costs has been the subject of public policy discussion in recent years in Europe, it has been for the most part in the context of concerns about access to justice, ${ }^{206}$ and the emphasis has been on reducing or eliminating costs generally. The discussion has been particularly intense in Germany, where it was argued that the imposition of any costs, or the risk of reimbursing the opponent in the event of defeat, violated the constitutional guarantee of access to the courts. ${ }^{207}$ This position, which was first presented in 1969 and reflects much of the prevailing sentiment of that time, has not, however, found universal acceptance. ${ }^{208}$ Among other things, it has been pointed out that while the settlement of disputes among private individuals is a public function that benefits society as a whole (especially as the principal substitute for the outlawed private enforcement of rights), it also benefits the immediate parties, and that particularly in cases where litigation serves no other purpose than the enforcement of undisputed claims, the defaulting party rather than the taxpayers should be required to bear the costs. ${ }^{209}$ It was also generally recognized, even by those who claimed that the imposition of costs was unconstitutional, that while the government could absorb the full expense of operating the courts without the danger of unfavorable side effects, a rule assigning responsibility for attorneys' compensation to the government would have serious implications and would probably be politically unacceptable. ${ }^{210}$ Nevertheless, a variety of schemes for reducing the cost burden were suggested and discussed in great detail, including universal compulsory legal expense insurance, partial elimination of the requirement of representation by attorneys, changes in the fee computation rules, and even authorization of contingent fee arrangements and alternative forms of dispute settlement.

Not surprisingly, the rules concerning cost allocation also came up for critical reexamination in this context. Viewed as a potential barrier impeding access to justice, the principal rule was found to be ambivalent: while promising freedom

206. This discussion is, as previously stated, beyond the scope of this article. See supra note 5.

207. Däubler, Bürger ohne Rechtsschutz?, 1969 BeTRIEBSBERATER 545; Fechner, Kostenrisiko und Rechtswegsperre-Steht der Rechtsweg offen.?, 1969 JURISTENZEITUNG 349.

208. See especially G. BAUMGÄrTEL, supra note 197, at 126-28; V. BuERMEyer, RechtSSCHUTzGARANTIE UND GERICHTSVERFAHRENSRECHT 181 (1975) (explaining the cost reimbursement rules of the administrative courts); Grunsky, supra note 181, at A82.

209. Pawlowski, supra note 181 , at $198-99$.

210. Bokelmann, supra note 188, at 170; Rehbinder, Die Kosten der Rechisverfolgung als Zugangsbarriere der Rechtspflege, 4 JAHRBUCH FÜR ReChtSSOZIOLOCIE UND ReChTSTHEORIE 395, 406 (1976). 
from costs in the event of success, it also threatened imposition of massive costs in the event of defeat, and the complexity of life and law made it increasingly difficult for litigants to be confident about the outcome of a case. ${ }^{211}$

To better understand the concerns and the proposals, it seems indispensable to have a look at some of the cases that triggered the discussion. In a well-publicized German case in 1964, an automobile manufacturer brought suit for an injunction and damages in the amount of DM $15,000,000$ (about $\$ 5,000,000$ at the then prevailing exchange rate) against a consumer report magazine for alleged deficiencies in a test report critical of the manufacturer's products. Because of the large amount of the claim, the magazine publisher faced legal fees that in the event of defeat would have bankrupted it. ${ }^{212}$ There were similar cases in which large corporations threatened individual critics with legal action involving huge fees. In one case, a physician had publicly objected to an advertising campaign conducted by the sugar industry which proclaimed, in essence, that sugar was good for one's health. The industry's trade association threatened to bring an action for an injunction and specifically pointed to the large legal fees that the physician would have to pay in the event an injunction were granted. ${ }^{213}$ Much attention was also given to cases involving disputes between corporations and minority stockholders, in which, as in the cases just mentioned, the general deterrent effect of the cost reimbursement rule was compounded by the large amount at which the cases were usually valued. ${ }^{214}$

The remedies suggested for such cases include a split system of fixing case values for fee calculation, giving the court the power in case of demonstrated economic need to let one party pay lawyer and court fees at a lower rate than the other party. ${ }^{215}$ This principle, first adopted by the [German] Patent Act of 1937 for infringement actions, was extended in 1965 to actions over infringements of other industrial property rights, actions based on alleged violations of the unfair trade practices act, and disputes between corporations and individual stockholders challenging resolutions passed at stockholder meetings. ${ }^{216}$ Draft legislation to give the principle general application in all civil cases was prepared by the Federal Department of Justice in 1970 but was not introduced after state court administrators expressed concern that the courts would be overwhelmed with petitions for revaluation. ${ }^{217}$

Other proposals aim at introducing, expanding, or institutionalizing some of the exceptions that have traditionally been recognized in some but not all countries. Specifically, it has been suggested for Germany that courts should have the power to deviate from the general rule when necessary to avoid hardship, ${ }^{218}$ and

211. Grunsky, supra note 181 , at A10-11.

212. Erdsiek, Beschränkung der Kritik auf dem Gebiet der Warentests durch hohe Streitwerte?, 1964 NEUE JURISTISCHE WOCHENSCHRIFT 912. It should be remembered that in Germany legal fees are fixed by statute and are graduated according to the amount at issue. See Suhr, supra note 122.

213. Fechner, supra note 207; Pawlowski, supra note 181, at 197.

214. Fechner, supra note 207.

215. Däubler, supra note 207; Grunsky, supra note 181.

216. See supra note 167.

217. See Rehbinder, supra note 210 , at 402-03.

218. G. BAUMGÄRTEL, supra note 197, at 157-58. 
that costs should be split among the parties when they disagree in good faith and the resolution of the dispute benefits both. ${ }^{219}$ Some prospals come very close to the American rule: one suggests adoption of the principle of non-reimbursement of attorney fees and other expenses as the rule, with an exception for frivolous actions; ${ }^{220}$ another proposal would establish as the general rule that out-of-court expenses (attorney fees, expert witness fees, and the like) be pooled and apportioned evenly among the parties, win or lose except when the loser, had he exercised due care, could have foreseen that the case would be decided against him. ${ }^{221}$ The authors of these proposals are well-aware of the problems involved in implementing them but consider them preferable to the present state of the law in Germany.

For appeals, it has been suggested that costs should be allocated separately for each stage according to the outcome of that stage, giving the losing party credit for the fact that he cannot be expected to be smarter than the court. ${ }^{222}$

In addition, there are proposals that would in at least two types of cases charge part of the cost to the government rather than to either of the parties. The first is that of a decision being overruled on appeal on the sole ground that the judge below made a mistake in applying a rule of procedural law. In such a case it can be said that neither party can be blamed for having caused the additional costs of the appeal; rather, it seems proper for the consequences of judges' mistakes to be borne by the government. ${ }^{223}$

The other type is a second appeal whose primary purpose is to preserve the unity of the law by resolving conflicts between decisions handed down by different courts of appeal. In such a case, it has been argued that it is really the public interest that is being served, rather than the interests of the individual parties, and therefore the entire costs of the appeal, including attorney fees, should be absorbed by the government. ${ }^{224}$

These are persuasive proposals, well worth considering. In general, however, the multitude and variety of possible litigation situations and the complexity of public policies which favor litigation in certain situations but abhor it in others have frustrated the search for general rules that would offer acceptable alternatives to the traditional rule. Even those who most forcefully argue that the existing rules are constitutionally deficient have had to admit that they are not able to offer a totally satisfactory alternative. ${ }^{225}$

219. Ehrig, supra note 30, at 253; see also Grunsky, supra note 181, at A66-69.

220. Bokelmann, supra note 188 , at 169-70.

221. Grunsky, supra note 181, at A66-73. Of all the proposals, this one offers the most elaborate discussion, though not the most convincing arguments. One of Grunsky's arguments is that the winner, moved by the elation and satisfaction of having won, would be in a magnanimous mood and not mind sharing the costs with the unfortunate loser. Grunsky rejects the idea of letting the courts assign costs according to equity as too vague; he concedes that the fault standard he proposes is not much more precise and is not an ideal solution, but he still considers it preferable to the existing rule, and he expects the courts to develop appropriate guidelines.

222. Seetzen, Prozesskosten und sozialer Rechtsstaal, 1971 ZEITSCHRIFT FÜr RECHTSPOLITIK 35.

223. Grunsky, supra note 181, at A52-53.

224. Id. at A55-58; Pawlowski, supra note 181, at 200.

225. Bokelmann, supra note 158, at 168; Pawlowski, supra note 181, at 197. 
Most significantly, no one has yet found a formula for distinguishing on the basis of objective, easily verifiable criteria between "good" and "bad" litigationthat is, between actions or defenses that are necessary, useful, or desirable for society and therefore are to be encouraged, and those that are a nuisance to be discouraged or suppressed, not to mention the large grey area in between, consisting of cases in which society has no stake either way. ${ }^{226}$ Not everyone seems to be comfortable with the idea of leaving the decision to the court, to be made individually for each case as it comes up for judgment without any standards to guide it. In view of the lack of practical alternatives, the majority, even among those who are not enthusiastic about the traditional rule, seem resigned to the need for keeping it, subject to the old and newly proposed exceptions mentioned.

Even the modest proposals for modification were eventually rejected when the German code of civil procedure was revised in 1977. Specifically rejected were proposals to order or permit the court to deviate from the rule in cases where: the issue concerned a doubtful question of law; the decision answers a question of law that had intentionally been left open by the legislature; the prevailing party had failed to prepare a necessary document in time, or completely, or clearly; the prevailing party had caused evidence to be admitted unnecessarily; and a party prevails on appeal solely because of an intervening legislative change. ${ }^{227}$

\section{VI}

\section{EMPIRICAL EVIDENCE}

The question that an American audience may now ask is whether the rules actually make a difference in the real world of litigation practice, court congestion, and delay. More precisely, have the European cost reimbursement rules to a significant extent discouraged potential litigants from going to court with meritless claims or defenses, and have they, on the other hand, encouraged those who have good claims or good defenses to enter into litigation?

The difficulties of trying to answer this question are evident, especially since the answer would be meaningful only in comparison with the answer to the corresponding question posed with respect to the American rule. The principal problem is that if the actual impact of the rule is to be considered at all, it becomes necessary to distinguish between "good" and "bad" litigation-a distinction for which, as this article has suggested, it is very difficult to develop objective standards and which, therefore, will always be highly subjective and unreliable for research purposes.

Some Europeans seem to need no "hard" evidence beyond that provided by casual observation to conclude that there exists a causal relation between the American Rule and the (perceived) high volume of litigation in the United States. ${ }^{228}$ Serious researchers are not as easily convinced. Even if one were to

226. This view has been expressed most clearly by Pawlowski, supra note 181, at 199

227. See Kommission, supra note 188 , at 226

228. See Davis, Legal Fees in the U.S.A., LAW SOC'Y GAZETTE, Feb. 3, 1982, at 1. The implied notion that the volume of litigation is higher in the United States than in England or in the rest of Europe and 
disregard the crucial distinction between good and bad litigation and were satisfied with just a comparison of general litigation levels, the task would be of gigantic dimensions and mind-boggling difficulty, considering the number of different jurisdictions to be measured on both sides of the Atlantic and the need to consider differences accounted for by other factors.

It should be remembered also that deterrence of frivolous or unnecessary litigation is not the only and not even the principal objective of the European cost allocation rules. One cannot, therefore, expect Europeans to make special efforts to test the actual effect of the rules on litigants or potential litigants. Moreover, since the American rule has never been seriously considered as an alternative, no one has bothered to compare the actual effect of traditional European rules with the hypothetical effect of a rule following the American model. Practically all the concern about frivolous and meritless litigation has been expressed in the context of programs or proposals offering essentially free litigation. In that context, opinions about the seriousness of the problem have been divided, and several studies have been undertaken to provide the data necessary to determine whether these concerns are valid.

First, however, it seems useful to point out that the prospect of recouping all expense upon successful completion of a lawsuit has not had the effect of making people completely unconcerned about costs. One could hypothesize, for instance, that an average citizen, expecting to become engaged in litigation only with a good case and a strong prospect of success, would not feel deterred by any costs under the European system. Surveys have shown, however, that respondents were indeed influenced by the potential costs when asked hypothetically whether they would consider litigation in certain situations. As one might have expected, persons in upper income brackets showed less reluctance to become engaged in litigation than those with lower incomes. ${ }^{229}$ It must be noted that the studies did not ask whether the respondents were aware of the cost reimbursement rule, nor did they distinguish between cases about which the respondents felt very confident and those about which they were doubtful. Thus, the results can be explained in different ways: ignorance of the rule, consideration of the cost risk remaining even under the rule, lack of confidence in the case, or lack of confidence in the courts.

Other studies have concentrated on the effect of legal expense insurance coverage on the behavior of prospective and active litigants. The coverage provided by legal expense insurance relieves the insured of the cost burden in all respects: court costs and expenses that must be advanced, the fees of the insured's own attorney, and, in the event of defeat, the reimbursable expenses of the opposing party. ${ }^{230}$ With the cost risk thus removed, one could expect these insureds to be less inhibited in asserting or defending their rights and consequently to be more frequently involved in litigation than similarly situated uninsured persons. This is indeed the promise of legal expense insurance as a means to promote access to

\footnotetext{
that the higher volume has something to do with cost rules is not easy to prove or disprove. Such an undertaking would require a separate study.

229. G. BALMGÄRTEL, supra note 197, at 118-19.

230. See Pfennigstorf, supra note 157, at 534-56.
} 
justice, and is a result to be welcomed -if the access is used prudently in matters that have merit and cannot be resolved without litigation. There is also a temptation, however, to engage in groundless or frivolous litigation.

Concerns that the ready availability of legal services and representation might lead to increased litigation and overcrowding of the courts have been expressed in the United States ever since the idea of legal expense insurance (or prepaid legal services) was first suggested. ${ }^{231}$ So far, however, it has been impossible either to confirm or to dispel these concerns empirically because the actual volume of legal expense insurance coverage in the population has not reached a level where it could have a measurable impact on total litigation and the workload of the courts.

In Europe, on the other hand, legal expense insurance was introduced more than sixty years ago and has long been accepted as a standard and popular type of insurance coverage. Its state of development is highest and its market penetration deepest in Austria, Switzerland, and Germany, where about forty percent of all households are covered by some form of legal expense insurance. The most popular form of insurance is that limited to automobile-related legal risks. Holders of such policies file claims in by far the greatest numbers and for the largest amounts. There are many other differences between legal expense insurance as practiced in Europe and the various types of legal services plans established in the United States during the past twenty years. They cannot be discussed here in detail. ${ }^{232}$ What matters is that legal expense insurance has been well enough established in Europe to provide a sufficiently broad base for empirical studies.

One study, undertaken in 1974 on a relatively small scale in the state of North Rhine-Westphalia in Germany, was based in part on written questionnaires mailed to 117 civil court judges, 43 criminal court judges, and 90 attorneys, in part on oral interviews (based on written questionnaires) with 60 persons covered by legal expense insurance, and in part on the responses of one major legal expense insurance company to written questions. The results of the study suggest that the elimination of the cost risk through insurance coverage was indeed a strong factor in the decision of insureds to seek the advice of an attorney, to bring suit, to state a claim against a third party at an amount higher than the loss actually incurred, or to appeal from an adverse decision. ${ }^{233}$

A much broader and much more ambitious study was commissioned by the German Federal Department of Justice and undertaken in 1979 by a research

231. See Pfennigstorf \& Kimball, Regulation of Legal Service Plans, in LEGal SERvice Plans, supra note 157 , at $87,157-60$. The implication that any increase in the volume of litigation brought about by legal expense insurance or legal service plans would be necessarily bad must be rejected. More litigation is to be expected and welcomed if it is necessary and not frivolous. Court congestion by unnecessary or frivolous litigation is a problem that needs to be addressed generally and fairly, whether the litigants are rich or poor and whether they are supported by legal service plans or finance their lawsuits themselves.

232. See Pfennigstorf \& Kimball, Aspects of Legal Expense Insurance: A Review of Four New Publications, 1983 Am. B. Found. Research J. 251; see also supra note 157. Americans who are not familiar with the European concept of legal expense insurance sometimes think that contingent fee arrangements (for plaintiffs) and the defense provided by liability insurers (for defendants) provide equivalent protection. It is true that these devices offer some protection in some cases, but it is not equivalent to the protection offered by legal expense insurance, as a cursory look at the above references will show.

233. M. Pfingsten, Der Einfluss der Rechtsschutzversicherung auf die Rechtsverwirklichung (1975) (doctoral dissertation, University of Freiburg). 
team of the Wissenschaftszentrum Berlin under the direction of Professor Erhard Blankenburg. ${ }^{234}$ To test the hypothesis that legal expense insurance coverage works as an incentive for increased litigation activity, the research team used a two-pronged approach. First, it conducted a survey among 853 residents of West Berlin, asking for data relating to insurance coverages, claims experience, and general behavior with respect to legal problems and dispute-settling procedures, in addition to the usual demographic characteristics. Second, the team analyzed about 3000 claim files of the Berlin offices of five legal expense insurers.

From their own survey, the researchers found that those respondents who were covered by legal expense insurance had consistently higher rates of seeking the advice of a lawyer or going to court in a variety of problem situations than those who did not have insurance coverage. But they also found that the insured respondents resorted more often to alternative sources of assistance, which were not covered by insurance, such as public or union legal aid bureaus or various consumer organizations. From this the authors concluded that the data supported the "recruitment thesis" rather than the "inducement thesis," meaning that the increased tendency to litigate was not the result of legal expense insurance coverage but that persons who by reason of their personality, education, or occupation were more inclined to litigate were also more likely than others to purchase insurance. $^{235}$

The study of insurance claim files first focused on the activities of attorneys. Among other things, it appeared that of all the cases in which insureds had contacted an attorney about private law controversies, about thirty percent actually resulted in litigation. In matters concerning enforcement of damage claims after automobile accidents (which contitutes the largest class of legal expense insurance claims), about twenty percent of the cases handled by attorneys ended in litigation. ${ }^{236}$ The other cases were for the most part settled by negotiation or were abandoned by the insureds after consultation. The authors of the study admit that there may be more cases in which actions are filed in court but are subsequently withdrawn upon receipt of a settlement offer from the defendant's liability insurer. In such cases, the plaintiff's attorney fees customarily are paid by the defendant's insurer and therefore are not billed to the legal expense insurer and may not appear in the claims files. This part of the study also suffers from lack of comparative data on cases involving uninsured clients. Without such data, one cannot say whether attorneys treat claims differently depending on whether the client is insured or not.

Another phase of the study tested the relative persistence of insured and uninsured litigants by comparing the frequency of settlement in lawsuits involving persons covered by legal expense insurance with the frequency appearing in general court statistics. The results were inconclusive except for traffic accident cases,

234. E. Blankenburg \& J. Fiedler, Die RechtsschutzVersicherungen und der STEIGENDE GeschäfTSANFall DER Gerichte (1981). For an English summary, see Blankenburg, Legal Insurance, Litigant Decisions, and the Rising Caseloads of Courts: A West German Study, 16 LAW \& SOC'Y REV. 601 (198182).

235. E. Blankenburg \& J. Fiedler, supra note 234, at 46.

236. Id. at 85 . 
where insured parties were found to settle somewhat less frequently than the average. ${ }^{237}$

Professor Blankenburg and his associates also tested the hypothesis that someone who by virtue of insurance coverage is relieved of the cost risk may himself be inclined to take greater risks in litigation and that attorneys advising insured clients may be more likely to recommend litigation, or an appeal from an adverse decision, even in cases of questionable or no merit. If that were true, insured litigants would show a higher failure rate, and a higher appeal rate, than litigants generally. The researchers found, on the contrary, that success rates were significantly higher, and appeal rates significantly lower, for most insured litigants in most areas, the only notable exception being the relatively small group of insureds operating a business and maintaining the insurance for their businessrelated legal matters. ${ }^{238}$

There is only one class of cases where the study found a strong correlation between the existence of legal expense insurance and the incidence of legal activity: petitions for review of traffic tickets. This class accounted for about twenty-eight percent of the total claims volume in the sample studied. Most of these reviews involved accidents, where the alleged traffic violation, if left unchallenged, could have an adverse effect on the outcome of liability issues or on insurance coverage. Other cases involved moving violations, which, if accumulated, could lead to suspension of driving privileges. In eight percent of the traffic ticket cases, however, the alleged offense was no more than a parking violation carrying a fine of less than $\$ 15.00$ and no other consequences. The authors suggest that a large portion of these petitions would not have been filed if the petitioners had had to bear the costs themselves. ${ }^{239}$ Indeed, the growing volume of petitions for review of traffic tickets, which constitute almost one-half of the caseload of the criminal divisions of municipal courts, ${ }^{240}$ has worried court officials and insurers for some time. Some insurers have started to impose limitations on this coverage. ${ }^{241}$

As their general conclusion, the authors state that "[l]egal expense insurance does not cause legal costs any more than accident insurance causes accidents." 242 Elaborating on this intentionally oversimplified statement, the authors interpret their findings as confirming a thesis advanced by the principal author of the study in other publications, that social inhibitions and "social costs" (meaning disadvantages and discomfort resulting from the disruption of social relationships) are much more powerful motivating forces than financial costs in determining whether a person will take legal action against another. ${ }^{243}$ In the view of the

237. Id. at $96-100$.

238. Id. at $100-13$.

239. Id. at $61-70$.

240. Id. at $68-70$.

241. Some insurers now exclude coverage for reviews of tickets for nonmoving violations and cover other minor traffic offenses subject to a deductible. See 32 Veröffentlichungen des BundesaufSICHTSAMTES FÜR DAS VERSICHERUNGSWESEN 346 (Oct. 31, 1983).

242. Blankenburg, supra note 234, at 622-23 (English summary).

243. E. Blankenburg, U. Reifner, I. Gorges \& F. Tiemann, Rechtsberatung: Soziale DefiniTION VON RECHTSPROBLEMEN DURCH RECHTSBERATUNGS-ANGEBOTE (1982); Blankenburg, Mobilisierung von Recht, 1 ZEITSCHRIFT FÜR ReCHTSSOzIOLOGIE (1980). 
authors, the study suggests, on the one hand, that legal expense insurance cannot generally be held responsible for increased or more intense litigation activity, and that in those areas where a strong correlation between insurance and litigation activity was found (in civil and criminal traffic cases), the proper response would not be restrictions on the availability of insurance or access to the courts but rather a review of the substantive and procedural rules that give rise to the disputes in question. ${ }^{244}$ On the other hand, the authors believe the study suggests caution in expectations with respect to government-sponsored legal expense insurance programs as a means of providing easier access to the courts. ${ }^{245}$

The authors may be a shade too confident in interpreting the results of their study since they concede that due to the traditional prevalence of traffic-related coverages, traffic-related claims were vastly overrepresented in their sample while all other matters occurred in small numbers of questionable statistical significance. ${ }^{246}$

Even more caution would seem to be in order in extrapolating the findings. The study looked only at matters and disputes covered under standard German legal expense policies, which are carefully designed to apply only to truly fortuitous events. If the cost risk were removed for other types of disputes, especially disputes not involving the close relationships cited as inhibiting factors by Professor Blankenburg, the results might be quite different. The legal expense insurance contract itself may be one of those inhibiting factors; if freedom from costs were provided on a broader and anonymous basis, more persons might be tempted to test their ideas in court.

Finally, one may readily agree with Professor Blankenburg that average, reasonable citizens generally have no inclination to go to court unless it is absolutely necessary to protect their rights. His sample was mostly composed of such average, reasonable citizens. Since the study was limited to persons and matters covered by legal expense insurance, he had no reason to explore specifically the attitude of lawyers, except in their dealings with persons carrying legal expense insurance. Lawyers, of course, are subject to inhibitions and incentives different from those of average citizens. And there are others, not only isolated individuals but whole groups, that do not share the inhibitions of the average.

- In other words, Blankenburg's study does not preclude the possibility that under other circumstances the elimination of cost risks might encourage some persons to go to court with unnecessary and undesirable actions. There are indeed indications that this is more than a theoretical possibility. Apart from the proliferation of petitions for review of traffic tickets, already mentioned, there have been complaints about abuses of the free legal procedures in social security matters. ${ }^{247}$ Further, there has been considerable concern about abuses in the area of unfair trade practices, where a consumer-minded legislature several years ago gave standing to organizations to petition the court for injunctions against instances of

244. E. Bl.ANKENBURG \& J. FiedLER, supra note 234, at 113-14.

245. Id. at 124-29.

246. Id. at $76-79,114$.

247. Pfeiffer, Knappe Ressource Recht, 1981 ZeItsChRIfT fÜr ReChtSPOLITIK 121, 125. 
unfair or misleading advertising. Instead of the consumer organizations and fair trade associations for which it was intended, however, the opportunity has been seized by enterprising lawyers who, behind the cover of specially created corporate fronts bearing a noble-sounding name, employ dozens of researchers combing through newspapers and magazines in search of advertisements containing some offensive matter that can be construed as misleading or otherwise in violation of the fair trade practices law. The offending advertiser is then put on notice, requested to cease and desist, and asked to pay to the complainant the applicable statutory attorney fees-which are the only objective of the operation and, in an office staffed with skilled employees handling a large volume of publications, generate substantial profits for the owners. ${ }^{248}$

Despite heroic efforts, the courts have been unable to stop these abuses permanently, due to the difficulty of finding satisfactory criteria for clearly distinguishing in advance between bona fide consumer organizations and the commercial feegenerating machines. ${ }^{249}$

This experience shows what can happen if access to the courts is opened liberally without adequate controls to prevent enterprising lawyers from exploiting the system as a source of easy fees. It should serve as a warning.

\section{VII}

\section{SUMMARY}

The history and present state of European rules on cost shifting, as well as recent proposals for their reform, reflect the dilemma, not unknown to Americans, posed by a variety of conflicting notions and attitudes:

(1) Costs generally are viewed as blemishes. Ideally, courts should be fully accessible to everyone free of cost.

(2) While the costs of maintaining and operating the courts themselves can, without too much difficulty, be absorbed by the government, attorneys-whose services are indispensable in most matters-must also be paid somehow, and shifting that burden to the government would create not only economic problems, but also problems with respect to attorneys' independence.

(3) There must be safeguards to prevent the system of civil procedure from being abused by debtors whose only aim is to delay or avoid paying an undisputed obligation; by persons who pursue unfounded or exaggerated claims for personal gain, for harassment, or to satisfy a distorted view of justice; or finally by lawyers whose only objective is to generate fees.

(4) It is difficult, if not impossible, to devise objective criteria for distinguishing between good faith litigation, which is to be encouraged, and bad faith litigation, which is to be discouraged.

248. See, e.g., Ungern-Sternberg, Verbandsklagebefugnis für Abmahnvereine?, 1981 NEUE JURISTISCHE WOCHENSCHRIFT 2328.

249. Id. (providing references to cases and proposed remedial legislation); see also Schmidt, Wettbewerbsrechtliche und vereinsrechlliche Instrumente gegen die Tätigkeit der Abmahnvereine, 36 NEVE JURISTISCHE WOCHENSCHRIFT 1520 (1983). 
(5) If bad faith is not found and the costs cannot be shifted to the government, there are only the two parties between which they can be allocated.

It is in the handling of the standard case, where bad faith is not evident, that the European practice deviates from that in the United States. The practice reflects in part the rationale that victory is not complete if it leaves substantial expenses uncovered. It also developed in part out of a deeply ingrained respect for the finality and dispositive authority of the judgment.

Thus emerges the general rule that the defeated must reimburse the victor for his expenses. Letting each party bear its own expenses is the exception. In special cases the victor may even be ordered to reimburse the defeated for all or part of his expenses.

It is in the nature and range of the exceptions and qualifications that there is the most variety among existing rules in the various European countries, as well as among proposals for their reform. Some exceptions were established by statute; some have been developed by the courts in the exercise of their discretion to deviate from the basic rule. One class of exceptions focuses on the conduct or state of mind of the victor. Another class recognizes special situations in which the defeated party's good faith seems to deserve special recognition, such as justified doubts about the interpretation of contract terms, or intervening changes in the law, or, in some recent proposals, conflicting decisions by different courts. A third class of exceptions gives recognition to differences in the economic position of the parties and seeks to prevent economic hardship. This last class has emerged most recently and is the one for which the pressure for further expansion has been greatest, as a result of general concerns about removing cost barriers impeding equal access to justice.

If costs are to be reimbursed by defeated parties even if they did not act in bad faith, there must be some kind of control over those costs. Although the control affects directly only the reimbursable part of the costs, it inevitably has a farther reaching effect both on the way in which lawyers conduct cases and bill their clients and on the way in which courts watch over the necessity and economy of procedures.

The intense discussion about access to justice has included a thorough reappraisal of the traditional rule of cost allocation. While the rule is not regarded as ideal (given that it does not eliminate costs), no acceptable alternative has been found. It can thus be safely predicted that the rule, subject perhaps to an expanding array of exceptions, will continue to dominate the European codes for the foreseeable future. 


\section{APPENDIX \\ Relevant Provisions from Codes and Regulations}

\section{INTRODUCTION}

Just as the article itself could not cover the entire law of costs, so it is obviously impossible to supply the text of all the provisions that affect the allocation of costs and the size of the cost burden. This Appendix, rather, is meant to serve two very limited purposes: first, it brings together in one place those provisions that are referred to most frequently in the text, relieving the footnotes of bulky and repetitious quotations from the codes; and second, the compilation of the central provisions on cost allocation from twelve countries should give readers a vivid impression of the similarities and dissimilarities not only in the substance of what is provided but also in legislative style and general approach to the subject.

The selection of the texts has been based on very crude standards. The material has been taken almost exclusively from the codes of civil procedure. There is, of course, no uniformity among the different countries with respect to the matters that they choose to regulate in their codes. Consequently, some of the details of cost allocation that are regulated in the code of civil procedure of one country may be dealt with in some other statute in another country. No attempt has been made to achieve complete parallelism by including such relevant provisions from other statutes. Moreover, some of the matters on which some countries have express statutory provisions are the subject of case law in other countries. Thus if certain provisions are found in this Appendix for some countries only, that should not be taken to mean that in the other countries the matter is unregulated.

The author has provided official or private translations where available. The remainder he has translated himself. A citation to the original language source, along with the dates of first enactment and latest revision, is included for each translation. All the translations suffer from the fact that the translated texts are taken out of the context of large codes. They employ terms of art that cannot simply be translated but must be explained in the context of the respective system of procedure. For the limited purposes for which the translations are used here, however, it seems possible to dispense with extensive annotations. The basic thrust of the provisions should be evident even though some of the details and some of the references to special procedures or institutions may remain obscure. 


\section{Austria* \\ Law Concerning Procedure in Givil litigation (Code of Civil Procedure) of August 1, 1895}

First Part: General Provisions

First Division: Parties

Fifth Title: Litigation Costs

\section{Section 40 .}

(1) Initially, each party is responsible for the payment of the costs caused by its procedural acts. The costs of judicial acts initiated jointly by the parties or performed by the court in the interest of both parties, whether on request or on the court's own motion, are to be paid jointly by both parties.

(2) To what extent the parties have a claim for reimbursement of the costs incurred by them is to be determined in accordance with the provisions of this title except where this code specifies otherwise.

\section{Section 41.}

(1) The party that loses completely in the litigation must reimburse the opponent, as well as the party intervening on the latter's side, for all costs that were caused by the litigation and were necessary for appropriate prosecution or defense. Which costs are to be regarded as necessary is to be determined by the court when specifying the amount of the costs, without allowing the presentation of evidence, in its discretion guided by careful consideration of all circumstances.

(2) So far as the remuneration of the attorney or the amount of the costs is regulated by schedules, the assessment of the amount of the costs is to be based on these schedules.

(3) The provisions of the first paragraph apply especially with respect to the costs caused by employing an attorney who does not reside where the court or the judge is located. The costs caused by employing several attorneys for the same party are in any event reimbursable only to the extent that they do not exceed the costs of employing one attorney or that a change of attorneys was necessary.

\section{Section 42.}

(1) In determining the litigation costs the party and intervening party cannot claim compensation for personal efforts. If their personal appearance before the court was necessary, and especially if the party in a proceeding before a district court appears without an attorney, compensation is to be paid for loss of time and travel expenses.

(2) If a party is represented by persons who are not attorneys at law or notaries, the losing opponent is only to be ordered to reimburse court fees, copy fees, and other official fees and the necessary cash expenses caused by the litigation.

\footnotetext{
* Source: Zivilprozessgesetze (R. Stohanzl ed. 1980). Translated by Werner Pfennigstorf.
} 


\section{AUSTRIA}

This provision does not apply, however, for cost reimbursement claims of parties represented by the Finanzprokuratur; in that case there is no difference whether the Finanzprokuratur acts directly or is in turn represented by administrative agencies or offices.

\section{Section 43.}

(1) If each party prevails in part and loses in part, the costs are to be set off against one another or are to be apportioned proportionally. The portion to be reimbursed may be specified in an amount or in proportion to the total costs.

(2) The court may, however, even in the event of such outcome impose on one party the duty to reimburse all costs incurred by the opponent and the parties intervening on the opponent's side if the opponent succumbed only with respect to a relatively minor part of his claim, the prosecution of which, moreover, has not caused any special costs, or if the amount of the opponent's claim was dependent on determination by judicial discretion, or assessment by experts, or on mutual calculation.

\section{Section 44 .}

(1) If allegations of facts or items of evidence are presented under circumstances from which the court is convinced that the party could have presented them earlier, and if admission of such material delays the disposition of the case, the court may, on request or on its own motion, impose reimbursement of all or part of the litigation costs on the party that has presented the material, even if it prevails.

(2) This applies in particular to allegations and evidence that should have been presented in one of the prevailing party's preparatory briefs and the delayed presentation of which has caused a delay of the trial or of the deposition of the case.

\section{Section 45 .}

If the defendant has not, through his conduct, provoked the action and has immediately, in the first hearing, acknowledged the claim pursued in the action, the litigation costs are at the charge of the plaintiff. The plaintiff must also reimburse the defendant for the costs caused by the court proceedings.

\section{Section $45 a$.}

(1) If divorce or dissolution of the marriage is ordered or if the marriage is annulled without the succumbing party being at fault, the costs are to be set off against one another.

(2) If the divorce is ordered under $\S 55$ of the Marriage Act, and if the divorce order contains a statement concerning who is to blame for the breakdown of the marriage, the spouse who is at fault has to reimburse the other spouse for the costs. 
AUstria

\section{Section 47.}

(1) The costs of a settlement are to be deemed to be set off against one another unless otherwise agreed. The same applies to the costs of the litigation resolved by the settlement, to the extent that they have not yet been imposed on one of the parties by an order that is not subject to appeal.

(2) If settlement negotiations are unsuccessful, the duty to reimburse the costs relating thereto depends on the disposition of the principal issue.

\section{Section 48 .}

(1) If costs are caused to a party by the fact that the opponent negligently delays the presentation of allegations of fact or evidence, or as a result of incidents occurring in the course of the proceedings through the opponent's fault or accidentally by the opponent, the court may on request or on its own motion award the party reimbursement of those costs regardless of the outcome of the case.

(2) The party to whom reimbursement of such costs has already been awarded during the course of the litigation is not obligated to refund them even if it is ordered to reimburse the litigation costs in the principal issue.

\section{Section 49 .}

(1) Legal representatives, attorneys-at-law, and other representatives may be ordered by the court, on request or the court's own motion, to bear or reimburse those costs that they have caused by gross negligence.

(2) This applies in particular to extra costs caused through gross negligence either by inclusion of nonmaterial factual allegations in the briefs or by superfluous verbosity in the briefs.

(3) If the decision is not included in the judgment on the principal issue, it is made in the form of an order. Prior to the decision the representative or attorney involved is to be heard. Upon becoming final, the order authorizes execution into the assets of these persons.

\section{Section 50.}

The provisions of $\S \S 40$ to 49 also apply to appeal proceedings and to the decisions to be made by the courts of the second and third instances causing the costs of the appeal, as well as, if a lower court decision is changed, concerning the costs of the entire previous proceedings. The fact that a party has been sustained by the lower courts is irrelevant for the question of cost reimbursement.

\section{Section 51 .}

(1) If proceedings are reversed or annulled on appeal or on the court's own motion and if at the same time one of the parties can be blamed for the fact that 
AUSTRIA

the proceedings were commenced or continued despite the existing grounds for reversal or annulment, or if the fault of one of the parties constitutes the ground for the reversal, that party may, on request or on the court's own motion, be ordered to reimburse the costs of the reversed proceedings, as well as of the appeal proceedings, if any.

(2) If the existing ground for reversal or annulment was disregarded due to obvious gross negligence on the part of the court, or if obvious gross negligence of the court has caused the reversal of the proceedings, reimbursement of the costs of the reversed proceedings and, if applicable, the appeal proceedings, may on request or on the court's own motion, be imposed on the court.

(3) Except for these costs, the costs are to be set off against one another.

\section{Section 52.}

(1) Every judgment and all orders that dispose completely of an issue for a stage in the proceedings, must also contain a decision concerning the reimbursement of costs. Other orders may contain cost reimbursement decisions only to the extent that the obligation is independent of the outcome of the princpal issue.

(2) If in issuing a partial judgment the court is unable to decide on the costs relating to the resolved claim or partial claim, it also is to be indicated in the judgment to what extent such decision is reserved for a later judgment.

(3) The decision concerning cost reimbursement is to be made without party motion, provided the statement of costs $(\S 54)$ was submitted in time.

\section{Section 53.}

(1) When deciding on the obligation to reimburse costs, the court shall at the same time specify the amount of the reimbursable costs, insofar as costs are not set off against one another.

(2) When orally announcing the judgment or an order imposing an obligation to reimburse costs, however, the court may, in all cases where the judgment or order is still to be executed in writing, reserve the specification of the amount of the costs for the written copy.

\section{Section 54.}

(1) The party claiming reimbursement for costs must, to avoid forfeiture of the reimbursement claim, submit the statement of the costs together with supporting documents to the court prior to the closing of the trial immediately preceding the decision on the cost reimbursement claim $(\S 52)$ or, if the decision is to be made without prior trial, at the hearing or together with its petition for decision.

(2) If a party incurs further reimbursable costs after the time at which according to paragraph 1 the cost statement must be submitted, it may request a supplement to the decision concerning the amount of reimbursable costs. The court decides by order without hearing. 


\section{Austria}

Section 55.

The decision on costs contained in a judgment of a trial court is only subject to recourse unless the decision on the principal issue is also appealed.

\section{BELGIUM* \\ JUdiciary CODE, LAW OF OCTOBER 10, 1976}

Fourth Part: Civil Procedure

Book II: Trial Courts

Title IV: Costs and Expenses

Article 1017.

All final judgments shall announce, on the court's own motion, the imposition of the costs on the defeated party, except as provided otherwise by special law, and leaving unaffected agreements among the parties as documented in the judgment.

The costs shall, however, except in case of a temerarious or vexatious claim, always be imposed on the agency or organization charged with the administration of the laws and regulations referred to in articles 580, 581, and 582 (nos. 1 and 2) with respect to claims made by or against beneficiaries.

The costs may be apportioned at a ratio specified by the judge either if both parties are defeated on some point or among spouses, ascendants, brothers and sisters or persons who are related by marriage to the same degree.

All interim judgments shall reserve the decision on the costs.

Article 1018.

The costs include:

1. The stamp, office, and registration fees;

2. the costs, emoluments, and salaries relating to judicial acts;

3. the costs of preparing a copy of the judgment;

4. the expenses of all fact-finding measures, notably the compensation of witnesses and experts;

5. the travel and lodging expenses of judges, clerks and parties if the travel has been ordered by the judge and the costs of documents if they have been prepared solely for the purpose of the litigation;

6. the amounts provided for in art. 1022.

Article 1021.

The parties may submit a detailed statement of their respective costs, including the compensation for expenses and procedure provided for in art. 1022. In that case, the judgment shall contain the assessment of these costs.

* Source: Codes Larcier, Tome I (1980). Translated by Werner Pfennigstorf. 


\title{
BELGIUM
}

If the costs are not assessed in the judgment, or are assessed only in part, the part not assessed is deemed reserved. In that case, the assessment is made, on the petition of the first party to do so, by the deciding judge, provided his decision has not been appealed: the proceedings are resumed and continued in accordance with articles 750 et seq.

\section{Article 1022.}

The King establishes, with the advice of the Council of the National Association of Advocates, a schedule of amounts of reimbursable costs, justified by the performance of certain pertinent actions.

Article 1023.

Any contractual provision purporting to increase the amount owed on account of its collection by legal action is deemed not written.

\section{Article 1024.}

The costs of execution are at the charge of the party against which execution is made.

\author{
DENMARK* \\ Judicial Code, Revised Version of January 2, 1980
}

Third Book: Civil Procedure

First Division: General Provisions

Chapter 30: Litigation Costs and Procedural Penalties

\section{Section 311 .}

(1) Each party has to pay the costs caused by procedural acts that it has requested or put in motion, subject, however, to the right to have them reimbursed by the opposing party in accordance with the following provisions.

(2) Costs of procedural acts required by the court may be required to be advanced either by the party in whose interest the court deems the act to be or by both parties in proportion specified by the court, subject, however, to $\S 284(2)$.

Section 312.

(1) The losing party is obligated to reimburse the opposing party for the costs caused by the litigation, except insofar as the parties have agreed otherwise, or the court for special circumstances finds it equitable to deviate from the rule.

\footnotetext{
* Source: Dansk Lovsamling (H. Topsoe-Jensen ed. 1980). Translated by Werner Pfennigstorf.
} 


\section{DenMark}

(2) Expenses that were not necessary for the proper conduct of the litigation are not to be reimbursed. The court decides in its discretion which expenses were necessary in the given case. Expenses for the employment of a court stenographer are to be reimbursed if in the court's discretion the employment in the given case was justified. The amount shall be assessed as an aggregate sum, with an appropriate amount to be reimbursed for attorney fees and the other expenses to be reimbursed in full so far as possible. Reimbursement incurred after the statement or generally in any other way than in form of a fixed amount specified in the judgment is not possible, even if there is an agreement between the parties.

(3) The fact that some points of an action or defense are rejected or that some of the evidence offered is regarded as not material for the case, shall not by itself necessarily preclude reimbursement of the expenses therefor.

(4) If a case becomes moot, the court may according to the circumstances order one party to reimburse the other party for all or part of its costs, or it may order that each of the parties shall bear its own costs (set-off of costs).

(5) If the defendant has lawfully offered to the plaintiff what the latter can claim, the plaintiff must reimburse the defendant for the latter's expenses for the subsequent part of the litigation.

\section{Section 313}

If the action is dismissed entirely, it is with respect to the costs deemed to be lost by the plaintiff.

Section 316.

(1) If each party prevails in part and loses in part, the costs are either to be paid partially by one of the parties or to be set off.

(2) However, the court may order one party to reimburse the opposing party for its costs if the amount of the latter's claim deviates only to a minor degree from that awarded by the court and if the difference has not caused special costs or expenses.

\section{Section 317.}

A party who by appeal does not obtain a modification of the appealed decision is deemed defeated in this respect and therefore as a rule has to reimburse the opposing party for its costs in the appeal.

\section{Section 318.}

If the judgment or order is modified on appeal, the decision on the costs of the appeal, as well as the costs of the previous proceeding, is made in accordance with the rules given in $\S \S 312-16$, and the costs are either imposed on the opposing party or are set off or divided. 
DENMARK

Section 319.

The party who through imputable fault or negligence has caused wasted hearing dates, unnecessary postponements, useless taking of evidence, or other superfluous or irrelevant procedural acts, is obligated, even if it prevails on the case, to reimburse the opposing party for the expenses caused thereby.

\section{Section 320.}

(1) With respect to the costs of individual procedural acts or stages of procedure, the court may decide immediately by order if that decision, as in the case dealt with in the preceding section, is independent of the outcome of the principal issue. If a separate decision is not made earlier, a provision in the final judgment is necessary with respect to such individual acts or stages of procedure.

(2) Expenses for the preparation of extracts for use in the documentation of cases appealed to the Supreme Court are to be paid to the government treasury by the appealing party, upon statement by the clerk of the Supreme Court, unless the procedure is free with respect to the party. The expenses are taken into account in the assessment of litigation costs in the judgment.

\section{Section 321 .}

Advocates or other representatives in litigation may, upon the request of the opposing party, be ordered to bear the costs that they have caused by conduct in violation of their duties. A party that submits such a request shall see to it that the advocate or representative is given an opportunity to respond to it.

\section{Section 322.}

The provisions of the preceding section apply also to judges of lower courts if a case is appealed to a higher court, provided that the judge whose order is appealed shall be given notice when the summons for the appeal is announced to the opposing party. The judge has the right to be heard by the higher court and to defend himself. In the case of an appeal from an order it is sufficient that the request concerning the judge is contained in the written appeal or in the entry in the court records that takes its place.

\section{ENGLAND AND WALES}

(a) Supreme Court Act, 1981, ch. 16.

Part II. Jurisdiction

General Provisions

Costs

Section 51 .

(1) Subject to the provisions of this or any other Act and to rules of court, the costs of and incidental to all proceedings in the civil division of the Court of 


\section{ENGLAND AND WALES}

Appeal and in the High Court, including the administration of estates and trusts, shall be in the discretion of the court, and the court shall have full power to determine by whom and to what extent the costs are to be paid.

\section{(b) Rules of the Supreme Court*}

Order 62: Costs

\section{ENTITLEMENT TO Costs}

When costs to follow the event (O. 62, r. 3).

3. (1) Subject to the following provisions of this Order, no party shall be entitled to recover any costs of or incidental to any proceedings from any other party to the proceedings except under an order of the Court.

(2) If the Court in the exercise of its discretion sees fit to make any order as to the costs of or incidental to any proceedings, the Court shall, subject to this Order, order the costs to follow the event, except when it appears to the Court that in the circumstances of the case some other order should be made as to the whole or any part of the costs.

(3) The costs of and occasioned by any amendment made without leave in the writ of summons or any pleading shall be borne by the party making the amendment, unless the Court otherwise orders.

(4) The costs of and occasioned by any application to extend the time fixed by these rules, or any direction or order thereunder, for serving or filing any document or doing any other act (including the costs of any order made on the application) shall be borne by the party making the application, unless the Court otherwise orders.

(5) If a party on whom a notice to admit facts is served under Order 27, rule 2 , refuses or neglects to admit the facts within 7 days after the service on him of the notice or such longer time as may be allowed by the Court, the costs of proving the facts shall be paid by him, unless the Court otherwise orders.

(6) If a party-

(a) on whom a list of documents is served in pursuance of any provision of Order 24, or

(b) on whom a notice to admit documents is served under Order 27, rule 5, gives notice of non-admission of any of the documents in accordance with Order 27 , rule $4(2)$ or $5(2)$, as the case may be, the costs of proving that document shall be paid by him, unless the Court otherwise orders.

(7) Where a defendant by notice in writing and without leave discontinues his counterclaim against any party or withdraws any particular claim made by him therein against any party, that party shall, unless the Court otherwise directs, be entitled to his costs of the counterclaim or his costs occasioned by the claim

* Source: 1 The Supreme Court Practice 1982, at 972, 1007-24, 1051-1071. 


\section{ENGLAND AND WALES}

withdrawn, as the case may be, incurred to the time of receipt of the notice of discontinuance or withdrawal.

(8) Where a plaintiff accepts money paid into Court by a defendant who counterclaimed against him, then, if the notice of payment given by that defendant stated that he had taken into account and satisfied the cause of action or, as the case may be, all the causes of action in respect of which he counterclaimed, that defendant shall, unless the Court otherwise directs, be entitled to his costs of the counterclaim incurred to the time of receipt of the notice of acceptance by the plaintiff of the money paid into court.

(9) Where any person claiming to be a creditor-

(a) seeks to establish his claim to a debt under any judgment or order in accordance with Order 44 , or

(b) comes in to prove his title, debt or claim in relation to a company in pursuance of any such notice as is mentioned in Order 102, rule 13

he shall, if his claim succeeds, be entitled to his costs incurred in establishing it, unless the Court otherwise directs, and, if his claim or any part of it fails, may be ordered to pay the costs of any person incurred in opposing it.

(10) Where a claimant is entitled to costs under paragraph (9), the amount of the costs shall be fixed by the Court unless it thinks fit to direct taxation and the amount fixed or allowed shall be added to the claimant's debt.

(11) Where a claimant (other than a person claiming to be a creditor) having established a claim to be entitled under a judgment or order in accordance with Order 44 has been served with notice of the judgment or order pursuant to rule 3 or 15 of that Order, he shall, if he enters an appearance, be entitled as part of his costs of action (if allowed) to costs incurred in establishing his claim, unless the Court otherwise directs; and where such a claimant fails to establish his claim or any part of it he may be ordered to pay the costs of any person incurred in opposing it.

(12) Where an application is made in accordance with Order 24, rule 7A, or Order 29, rule 7A, for an order under section 33 or 34 of the Act, the person against whom the order is sought shall be entitled, unless the Court otherwise directs, to his costs of and incidental to the application and of complying with any order made thereon and he may, after giving the applicant 7 days' notice of his intention to do so, tax such costs and, if they are not paid within 4 days after taxation, sign judgment for them.

Special matters to be taken into account in exercising discretion (O. 62, r. 5).

5. The Court in exercising its discretion as to costs shall, to such extent, if any, as may be appropriate in the circumstances, take into account-

(a) any such offer of contribution as is mentioned in Order 16 , rule 10 , which is brought to its attention in pursuance of a reserved right to do so;

(b) any payment of money into court and the amount of such payment. 


\section{ENGLAND AND WALES}

Restriction of discretion to order costs (O. 62, r. 6).

6. (1) Notwithstanding anything in this Order or in section 51 of the Act,-

(a) no order shall be made directing one party to pay to the other any costs of or incidental to an appeal or application for leave to appeal under section 6(2) of the Pensions Appeal Tribunals Act 1943;

(b) no order shall be made for costs to be paid by or to any person (other than the registration officer) who is respondent to an appeal to the Court of Appeal from the decision of a county court on the hearing of an appeal from the registration officer under section 45 of the Representation of the People Act, 1949, unless that person appears in support of the decision of the county court;

(c) unless the Court is of opinion that there was no reasonable ground for opposing the will, no order shall be made for the costs of the other side to be paid by the party opposing a will in a probate action who has given notice with his defence to the party setting up the will that he merely insists upon the will being proved in solemn form of law and only intends to cross-examine the witnesses produced in support of the will;

(d) except in special circumstances, no order shall be made giving more than one set of costs among all the opponents of a petition or originating summons for extension of the term of a patent under section 23, 24 or 25 of the Patents Act, 1949, if the Court refuses the prayer of the petition or the relief sought by the summons.

(2) Where a person is or has been a party to any proceedings in the capacity of trustee, personal representative or mortgagee, he shall, unless the Court otherwise orders, be entitled to the costs of those proceedings, in so far as they are not recovered from or paid by any other person, out of the fund held by the trustee or personal representative or the mortgaged property, as the case may be; and the Court may otherwise order only on the ground that the trustee, personal representative or mortgagee has acted unreasonably or, in the case of a trustee or personal representative, has in substance acted for his own benefit rather than for the benefit of the fund.

Costs arising from misconduct or neglect (O. 62, r. 7).

7. (1) Where in any cause or matter any thing is done or omission is made improperly or unnecessarily by or on behalf of a party, the Court may direct that any costs to that party in respect of it shall not be allowed to him and that any costs occasioned by it to other parties shall be paid by him to them.

(2) Without prejudice to the generality of paragraph (1) the Court shall for the purpose of that paragraph have regard in particular to the following matters, that is to say-

(a) the omission to do any thing the doing of which would have been calculated to save costs; 


\section{ENGLAND AND WALES}

(b) the doing of any thing calculated to occasion, or in a manner or at a time calculated to occasion, unnecessary costs;

(c) any unnecessary delay in the proceedings.

(3) The Court may, instead of giving a direction under paragraph (1) of this rule in relation to any thing done or omission made, direct the taxing officer to inquire into it and, if it appears to him that such a direction as aforesaid should have been given in relation to it, to act as if the appropriate direction had been given.

(4) The taxing officer shall, in relation to any thing done or omission made in the course of taxation and in relation to any failure to procure taxation, have the same power to disallow or to award costs as the Court has under paragraph (1) to direct that costs shall be disallowed to or paid by any party.

(5) Where a party entitled to costs fails to procure or fails to proceed with taxation, the taxing officer in order to prevent any other parties being prejudiced by that failure, may allow the party so entitled a nominal or other sum for costs or may certify the failure and the costs of the other parties.

(6) In this rule "taxing officer" means a taxing master, a registrar of the Principal Probate Registry, the Admiralty registrar or the registrar of a district registry.

Personal liability of solicitor for costs (O. 62, r. 8).

8. (1) Subject to the following provisions of this rule, where in any proceedings costs are incurred improperly or without reasonable cause or are wasted by undue delay or by any other misconduct or default, the Court may make against any solicitor whom it considers to be responsible (whether personally or through a servant or agent) an order-

(a) disallowing the costs as between solicitor and his client; and

(b) directing the solicitor to repay to his client costs which the client has been ordered to pay to other parties to the proceedings; or

(c) directing the solicitor personally to indemnify such other parties against costs payable by them.

Fractional or gross sum in place of taxed costs (O. 62, r. 9).

9. (1) Subject to this Order, where by or under these rules or any order or direction of the Court costs are to be paid to any person, that person shall be entitled to his taxed costs.

(4) The Court in awarding costs to any person may direct that, instead of taxed costs, that person shall be entitled-

(a) to a proportion specified in the direction of the taxed costs or to the taxed costs from or up to a stage of the proceedings so specified; or

(b) to a gross sum so specified in lieu of taxed costs. 


\section{ENGLAND AND WALES}

Provisions as to taxation proceedings (O. 62, r. 26).

26. (1) If any party entitled to be heard in any taxation proceedings does not attend within a reasonable time after the time appointed for the taxation, the taxing officer, if satisfied by affidavit or otherwise that the party had due notice of the time appointed, may proceed with the taxation.

(2) The taxing officer by whom any taxation proceedings are being conducted may, if he thinks it necessary to do so, adjourn those proceedings from time to time.

Powers of taxing officer taxing costs payable out of fund (O. 62, r. 27).

27. (1) Where any costs are to be paid out of a fund the taxing officer may give directions as to the parties who are entitled to attend on the taxation of those costs and may disallow the costs of attendance of any party not entitled to attend by virtue of the directions and whose attendance he considers unnecessary.

(2) Where the Court has directed that a bill of costs be taxed for the purposes of being paid out of a fund the taxing officer by whom the bill is being taxed may, if he thinks fit, adjourn the taxation for a reasonable period and direct the party whose bill it is to send to any person having an interest in the fund a copy of the bill, or of any part thereof, free of charge together with a letter containing the following information, that is to say-

(a) that the bill of costs, a copy of which or of part of which is sent with the letter, has been referred to a taxing officer for taxation;

(b) the name of the taxing officer and the address of the office at which the taxation is proceeding;

(c) the time appointed by the taxing officer at which the taxation will be continued; and

(d) such other information, if any, as the taxing officer may direct.

\section{ASSESSMENT OF Costs}

Costs payable to one party by another or out of a fund (O. 62, r. 28).

28. (1) This rule applies to costs which by or under these rules or any order or direction of the Court are to be paid to a party to any proceedings either by another party to those proceedings or out of any fund (other than a fund which the party to whom the costs are to be paid holds as trustee or personal representative).

(2) Subject to the following provisions of this rule, costs to which this rule applies shall be taxed on the party and party basis, and on a taxation on that basis there shall be allowed all such costs as were necessary or proper for the attainment of justice or for enforcing or defending the rights of the party whose costs are being taxed.

(3) The Court in awarding costs to which this rule applies may in any case in which it thinks fit to do so order or direct that the costs shall be taxed on the common fund basis.

(4) On a taxation on the common fund basis; being a more generous basis than that provided for by paragraph (2), there shall be allowed a reasonable 


\section{ENGLAND AND WALES}

amount in respect of all costs reasonably incurred, and paragraph (2) shall not apply; and accordingly in all cases where costs are to be taxed on the common fund basis the ordinary rules applicable on a taxation as between solicitor and client where the costs are to be paid out of a common fund in which the client and others are interested shall be applied, whether or not the costs are in fact to be so paid.

(5) The Court in awarding costs to which this rule applies to any person may if it thinks fit and if-

(a) the costs are to be paid out of a fund; or

(b) the person to whom the costs are to be paid is or was a party to the proceedings in the capacity of trustee or personal representative,

order or direct that the costs shall be taxed as if that person were a trustee of the fund or as if the costs were to be paid out of a fund held by that person, as the case may be, and where the Court so orders or directs rule 31(2) shall have effect in relation to the taxation in substitution for paragraph (2) of this rule.

Costs of a litigant in person (O. 62, r. 28A).

28A. (1) On a taxation of the costs of a litigant in person there may, subject to the provisions of this rule, be allowed such costs as would have been allowed if the work and disbursements to which the costs relate had been done or made by a solicitor on the litigant's behalf.

Costs payable to a solicitor by his own client (O. 62, r. 29).

29. (1) On the taxation of a solicitor's bill to his own client (except a bill to be paid out of the legal aid fund under the Legal Aid Act 1949, or a bill with respect to non-contentious business) all costs shall be allowed except in so far as they are of an unreasonable amount or have been unreasonably incurred.

(2) For the purposes of paragraph (1), all costs incurred with the express or implied approval of the client shall, subject to paragraph (3), be conclusively presumed to have been reasonably incurred and, where the amount thereof has been expressly or impliedly approved by the client, to have been reasonable in amount.

(3) For the purpose of paragraph (1), any costs which in the circumstances of the case are of an unusual nature and such that they would not be allowed on a taxation of costs in a case to which rule 28 (2) applies shall, unless the solicitor expressly informed his client before they were incurred that they might not be so allowed, be presumed, until the contrary is shown, to have been unreasonably incurred.

(4) In paragraphs (2) and (3), the references to the client shall be construed-

(a) if the client was at the material time incapable by reason of mental disorder within the meaning of the Mental Health Act 1959, of managing and administering his property and affairs and represented by a person acting as guardian ad litem or next friend, as references to that 


\section{ENGLAND AND WALES}

person acting, where necessary, with the authority of the authority having jurisdiction under Part VIII of that Act.

(b) If the client was at the material time an infant and represented by a person acting as guardian ad litem or next friend, as references to that person.

(5) Section 118(2) and (3) of the Mental Health Act 1959, shall have effect in relation to paragraph (4) as if that paragraph were an enactment and the reference in that paragraph to the authority having jurisdiction under Part VIII of that Act shall be construed accordingly.

Costs payable to solicitor where money recovered by or on behalf of infant, etc. (O. 62, r. 30).

30. (1) This rule applies to-

(a) any proceedings in which money is claimed or recovered by or on behalf of, or adjudged or ordered or agreed to be paid to, or for the benefit of, a person who is an infant or incapable by reason of mental disorder within the meaning of the Mental Health Act 1959, of managing and administering his property and affairs or in which money paid into Court is accepted by or on behalf of such a person, and

(b) any proceedings under the Fatal Accidents Act 1976, in which money is recovered by or on behalf of, or adjudged or ordered or agreed to be paid to, or for the benefit of, the widow of the person whose death gave rise to the proceedings in satisfaction of a claim under the said Act or in which money paid into Court is accepted by her or on her behalf in satisfaction of such a claim, if the proceedings were for the benefit also of a person who, when the money is recovered, or adjudged or ordered or agreed to be paid, or accepted, is an infant, and

(c) any proceedings in the Court of Appeal on an application or appeal made in connection with any proceedings to which this rule applies by virtue of the foregoing provisions of this paragraph.

(2) Unless the court otherwise directs the costs payable to his solicitor by any plaintiff in any proceedings to which this rule applies by virtue of paragraph $1(a)$ or (b), being the costs of those proceedings or incident to the claim therein or consequent thereon, shall be taxed under rule 29; and no costs shall be payable to the solicitor of any plaintiff in respect of those proceedings except such amount of costs as may be certified in accordance with this rule on the taxation under rule 29 of the solicitor's bill to that plaintiff.

(3) On the taxation under rule 29 of a solicitor's bill to any plaintiff in any proceedings to which this rule applies by virtue of paragraph 1 (a) or (b) who is his own client, the taxing officer shall also tax any costs payable to that plaintiff in those proceedings and shall certify-

(a) the amount allowed on the taxation under rule 29, the amount allowed on the taxation of any costs payable to that plaintiff in those proceed- 


\section{ENGLAND AND WALES}

ings and the amount (if any) by which the first mentioned amount exceeds the other, and

(b) where necessary, the proportion of the amount of the excess payable respectively by, or out of money belonging to, any party to the proceedings who is an infant or incapable, by reason of mental disorder within the meaning of the Mental Health Act 1959, of managing and administering his property and affairs or the widow of the man whose death gave rise to the proceedings and any other party.

(4) Paragraphs (2) and (3) shall apply in relation to any proceedings to which this rule applies by virtue of paragraph (1)(c) as if for references to a plaintiff there were substituted references to the party, whether appellant or respondent, who was the plaintiff in the proceedings which gave rise to the first-mentioned proceedings.

(5) Nothing in the foregoing provisions of this rule shall prejudice a solicitor's lien for costs.

(6) Where in any proceedings to which this rule applies directions given by the Court under Order 80 , rule 12 provide for the transfer or payment of money to or into a county court and for the payment to the solicitor of any plaintiff in the proceedings of an amount in respect of costs out of the money so transferred or paid, the taxing officer by whom those costs are taxed shall send a copy of his certificate to the registrar of the county court.

(7) The foregoing provisions of this rule shall apply in relation to-

(a) a counterclaim by or on behalf of a person who is an infant or incapable by reason of mental disorder within the meaning of the Mental Health Act 1959, of managing and administering his property and affairs and a counterclaim consisting of or including a claim under the Fatal Accidents Act 1976, by or on behalf of the widow of the man whose death gave rise to the claim, and

(b) a claim made by or on behalf of a person who is an infant or incapable as aforesaid in an action by any other person for relief under section 504 of the Merchant Shipping Act 1894, and a claim consisting of or including a claim under the Fatal Accidents Act 1976, made by or on behalf of that widow in such an action.

if for references to a plaintiff there were substituted references to a defendant.

Costs payable to a trustee out of the trust fund, etc. (O. 62, r. 31 ).

31. (1) This rule applies to every taxation of the costs which a person who is or has been a party to any proceedings in the capacity of trustee or personal representative is entitled to be paid out of any fund which he holds in that capacity.

(2) On any taxation to which this rule applies, no costs shall be disallowed, except in so far as those costs or any part of their amount should not, in accordance with the duty of the trustee or personal representative as such, have been incurred or paid, and should for that reason be borne by him personally. 


\section{ENGLAND AND Wales}

Scales of costs (O. 62, r. 32).

32. (1) Subject to the foregoing rules and the following provisions of this rule, the scale of costs contained in Appendix 2 to this Order, together with the notes and general provisions contained in that Appendix, shall apply to the taxation of all costs incurred in relation to contentious business done on or after January 1 , 1960.

(2) On a taxation in relation to which rule 29 or rule 31 (2) has effect and in other special cases costs may at the discretion of the taxing officer be allowed-

(a) in relation to items not mentioned in the said scale; or

(b) of an amount higher than that prescribed by the said scale.

(3) Where the amount of a solicitor's remuneration in respect of non-contentious business connected with sales, purchases, leases, mortgages and other matters of conveyancing or in respect of any other non-contentious business is regulated (in the absence of agreement to the contrary) by any general orders for the time being in force under the Solicitors Act 1974, the amount of the costs to be allowed on taxation in respect of the like contentious business shall be the same, notwithstanding anything in the scale contained in Appendix 2 to this Order.

(4) Notwithstanding paragraph (1) costs shall, unless the Court otherwise orders, be allowed in the cases to which Appendix 3 to this Order applies in accordance with the provisions of that Appendix.

\section{FRANCE*}

New Code of Givil Procedure Promulgated by Decret of December 5, 1975

Book I: Provisions Common to All Courts

Title XVIII: Expenses and Costs

\section{Chapter I}

The Burden of the Costs

Article 695

The costs relating to proceedings, documents, and execution procedures include:

1. The fees, taxes, or government royalties, or emoluments levied by the clerks of the courts or by the tax administration, with the exception of fees, taxes, and penalties which may be due on documentary evidence produced in support of the claims of the parties.

2. The expenses of transporting judges and clerks of court.

3. Compensation of witnesses.

4. Experts' fees.

* Source: New Code of Civil Procedure in France, Book 1: An English Translation by Francoise Grivart de Kerstrat and William E. Crawford (1978). Copyright $(\mathcal{O} 1978$ by Oceana Publications, Inc. Reprinted by permission of Oceana. 
FRANCE

5. Tariffed disbursements.

6. Emoluments of public or ministerial officials.

7. Avocats' fees insofar as they are regulated.

\section{Article 696.}

Costs are assessed against the losing party unless the judge assesses the whole or a part of the burden against the other party, in a decision with reasons given.

\section{Article 697}

Avocats, avoués and sheriffs "may be held" personally liable for the costs relating to proceedings, documents, and execution procedures instituted outside the scope of their mandate. (D. 76-14, July 29, 1976)

\section{Article 698}

The costs relating to "unjustified" proceedings, documents, and execution procedures are borne by the legal officials (auxiliaires de justice) who carried them out, without prejudice to the damages which might be claimed. The same applies to costs relating to proceedings, documents and execution procedures which are null as a result of the fault of those officials. (D. 76-714, July 29, 1976)

\section{Article 699}

Avocats and avoues may, in the matters where their representation is required, request that the assessment of costs carry with it, to their benefit, their right to recover directly agairist the party against whom costs have been assessed, the expenses which they advanced without having received a retainer.

The party against whom the recovery is pursued may, however, deduct, by legal set-off, the amount of the costs to his credit.

\section{Article 700 .}

When it appears inequitable to leave on one party the burden of the "sums spent by the latter and" not included in the costs, the judge may order the other party to pay the first one a sum which the judge determines. (D. 76-714, July 29, 1976)

\section{Chapter III}

The Recovery of Costs Against an Opponent

Article 704

The parties may, in case of difficulty, without formality request the clerk of the court which gave the ruling, to verify the amount of the costs.

The same applies to the legal official who wishes to recover costs; his request is 
France

then accompanied by a detailed account which he is bound to deliver to the parties in accordance with the tariff regulations. This account sets forth the retainer received.

\section{Article 705.}

The clerk of the court verifies the amount of the costs after having made, where appropriate, the necessary corrections in order to make the account conform to the tariffs. He delivers or sends by ordinary mail a certificate of verification to the interested person.

The moving party gives notice of the verified account to the opponent, who has a delay of one month to contest it. The notification carries with it the moving party's acceptance of the verified account.

It must set forth the delay and the formalities for contesting the account.

\section{Article 707.}

In the absence of a contesting by the opponent within the delay, the moving party may request the verifying clerk of the court to mention this on the certificate of verification. This note gives it executory force.

\section{Article 708.}

The person who wishes to contest the verification may always himself submit a request for an assessment order; he may also do it through his representative.

The request is made orally or in writing to the clerk of the court who verified the account. It must be accompanied by the certificate of verification.

\section{Article 710.}

The judge rules on the assessment request as well as on the other requests relating to the recovery of costs.

\section{Article 711.}

The judge makes, sua sponte, all the corrections necessary to make the account conform to the tariffs. He mentions, where appropriate, the sums already collected by way of retainer.

\section{Article 712.}

The judge has the power to refer the request as it stands to a court hearing on the date which he fixes. 


\section{GENEVA*}

Law of Civil Procedure of October 13, 1920

First Part: Adversary Proceedings

Title XI: Costs

Article 122.

(1) All judgments, including those on incidental issues, shall impose the costs on the defeated party.

(2) However, a part of the costs may be imposed on the prevailing party if it has incurred unnecessary expenses or if claims were exaggerated, leaving unaffected the penalties that may be imposed on the parties.

Article 123.

If costs are imposed on several parties, they are apportioned among the parties by heads or according to their respective interests in the litigation.

Article 125.

If both parties are defeated on some point respectively, the costs are apportioned among them at a proportion specified by the judges.

Article 126.

The judges may always apportion the costs among spouses, ascendants and descendants, brothers and sisters, persons related by marriage in the same degree, and partners, as required by equity.

Article 127.

Guardians, custodians and other administrators who in a litigated case have harmed the interests administered by them may be ordered to pay the costs, personally and excluding reimbursement.

Article 128.

The judges may authorize direct collection of costs by advocates who at the announcement of the judgment affirm that they are entitled to those costs.

Article 129.

The costs include:

(a) taxes, including registration tax on documents submitted;

* Source: Législation Genevoise, Tome 4, Livre E (1978) (Procédure civile). Translated by Werner Pfennigstorf. 


\section{Geneva}

(b) fees due the office of the court, the advocates, and the bailiffs, assessed according to schedule;

(c) a court fee assessed according to the advocates' fee schedule, taking into consideration the importance of the matter and the amount of work required by it;

(d) compensation for witnesses and experts;

(e) travel and lodging expenses of the parties if the travel was made exclusively for the litigation;

(f) travel expenses to a court outside the canton;

$(g)$ an equitable compensation, specified by the court, to contribute to the advocate's honorarium.

Article 130.

(1) Each party shall submit to the office of the court with its brief for the judgment, a statement of costs, prepared and signed by the advocate.

(2) The amounts pertaining to each item of the preceding article are to be set out separately, and detailed accounts are to be provided for each item.

(3) Supporting documents are to be attached to the statement where applicable.

\section{Article 131}

Where no advocate has been employed, the statement of costs is prepared by the office of the court.

\section{Article 132.}

(1) The statement of costs at the charge of one or the other party shall be examined and approved by the judges before whom the case is pending. The statement shall be attached to the original judgment, and it shall be incorporated in copies of the judgment for execution.

Article 133.

From the said statement, the following shall be rejected:

(a) all wasteful acts and all superfluous writings;

(b) all items whose cost is not indicated in detail. 


\section{Germany (Federal RePublic)*}

Code of Givil Procedure of January 30, 1877.

First Book: General Provisions

Second Division: Parties

Fifth Title: Litigation Costs

\section{Section 91.}

[Principles and extent of duty to bear costs] $\dagger$

(1) The losing party must bear the costs of the litigation, and must in particular reimburse the costs incurred by the opponent insofar as they were necessary for appropriate assertion or defense of rights. Reimbursement of costs includes compensation for the loss of time caused to the opponent by necessary travels or by necessary presence at hearings; the provisions concerning compensation of witnesses apply as appropriate.

(2) The statutory fees and expenses of the attorney of the prevailing party must be reimbursed in all proceedings; however, travel expenses of an attorney who is not admitted to practice before the court nor resides where the court is located are to be reimbursed only to the extent that retaining that at torney was necessary for appropriate enforcement or defense of rights. The prevailing party is not entitled to reimbursement of extra costs caused by the fact that the attorney admitted to practice before the court does not have his residence or his office where the court or an external department of the court is located. The costs of several attorneys are to be reimbursed only to the extent that they do not exceed the costs of a single attorney or that a change of attorneys was necessary. An attorney pleading his own case is entitled to reimbursement for the fees and expenses that he could claim as fees and expenses of a retained attorney.

(3) The costs of litigation referred to in paragraphs 1 and 2 include the fees incurred in a conciliation proceeding before a conciliation office established or recognized by the state court administration; this does not apply if more than one year has elapsed between the conclusion of the conciliation proceeding and the institution of the action.

Section 91 .

[Costs if case is declared moot]

(1) If the parties have declared the case moot with respect to the principal issue, the court decides on the costs in equitable discretion, taking into consideration the current state of the facts and the arguments. This decision is made in form of an order.

* Source: Deutsche Gesetze: Sammlung des Zivil-, Straf-, und Verfahrensrechts 29 (1977). Translated by Werner Pfennigstorf

$\dagger$ The headings in brackets are not part of the official text 


\section{Germany}

(2) The order is subject to immediate appeal. Before deciding on the appeal, the opponent must be heard.

\section{Section 92.}

[Division of costs in case of partial success]

(1) If each party prevails in part and loses in part, the costs are to be set off against one another or to be apportioned proportionally. If the costs are set off against one another, one-half of the court costs is imposed on each party.

(2) The court may impose the total litigation costs on one party if the excess of the other party's claim was relatively minor and did not cause extra costs or if the amount of the other party's claim was dependent on determination by judicial discretion, on assessment by experts, or on mutual calculation.

\section{Section 93.}

[Costs in case of immediate acknowledgement]

If the defendant has not, through his conduct, provoked the action, the litigation costs are imposed on the plaintiff if the defendant immediately acknowledges the claim.

\section{Section 93a.}

[Costs in marital matters]

(1) If the dissolution of a marriage is ordered, the costs of the divorce proceedings and the consequential issues decided simultaneously or decided previously under $\S 627(1)$ are to be set off against one another if that issue is decided separately as a result of separation under $\S 628(1)$, sentence 1 . The court may in equitable discretion allocate the costs differently if allocation under sentence 1 would unreasonably impair the lifestyle of one of the spouses or if that allocation of costs appears inequitable in view of the fact that one of the spouses has lost wholly or partially on consequential issues of the kind specified in $\$ 621(1)$ nos. 4, 5,8 . If the parties have made an agreement concerning the costs, the court may base its decision on it in whole or in part.

(2) If a petition for divorce is denied, the petitioner also has to bear the costs of the consequential issues rendered moot by the denial; this includes the costs of consequential issues to be decided separately as a result of separation under $\S 623(1)$, sentence 2 or $\S 628(1)$, sentence 1 . The court may allocate the costs differently if allocation under sentence 1 appears to be inequitable in view of the current state of the facts and arguments in consequential issues of the kind specified in $\S 621(1)$ nos. $4,5,8$.

(3) If a marriage is dissolved or annulled, the litigation costs are set off against one another. The court may in equitable discretion allocate the costs differently if allocation under sentence 1 would unreasonably impair the lifestyle of one of the spouses or if that allocation of costs appears inequitable in view of the fact that only one of the spouses had knowledge of the dissolvability or nullity of 


\section{GERMANY}

the marriage or if one spouse had been induced to agree to the marriage by fraud or illegal threats committed by the other spouse or with the other spouse's knowledge at the time of the marriage in the cases of $\$ \S 30-32$ of the Marriage Act.

(4) Paragraph 3 does not apply if a marriage is annulled on the petition of the state attorney or in the case of $\S 20$ of the Marriage Act on the petition of the former spouse.

\section{Section 93b.}

[Costs in action for vacation]

(1) If an action for vacation of a dwelling is sustained on the ground that the defendant's demand to continue the lease is not justified under $\$ \S 556 \mathrm{a}-\mathrm{b}$ of the Civil Code because of the lawful interests of the plaintiff, the court may impose all or part of the costs on the plaintiff if the defendant had given reasons for his demand to continue the lease and

1. the plaintiff prevails on grounds that have only arisen subsequently ( $§ 556 a(1)$ sentence 3 of the Civil Code), or

2. the plaintiff, in the cases of $\S 556 \mathrm{~b}$ of the Civil Code, has not informed the defendant of his lawful interests without delay. This applies as appropriate in litigation over continuation of a lease after an action has been dismissed.

(2) If an action for vacation of a dwelling is dismissed in view of the fact that on the demand of the defendant the continuation of the lease is ordered under $\S \S 556 \mathrm{a}-\mathrm{b}$ of the Civil Code, the court may impose all or part of the costs on the defendant if he has not, immediately upon the request of the plaintiff, specified the grounds for his objections. This applies as appropriate in litigation over continuation of a lease if the action is sustained.

(3) If the defendant immediately acknowledges the demand to vacate but is granted a period of grace for vacating, the court may impose all or part of the costs on the plaintiff if the defendant had already prior to the bringing of the action unsuccessfully requested the plaintiff, with specified reasons, to grant a continuation of the lease or a reasonable period for vacating.

\section{Section 93c}

[Costs in actions challenging legitimacy]

If an action to have a child declared illegitimate, or an action brought by the man who has acknowledged paternity, or his parents, or the child, to have the acknowledgement of paternity declared void, succeeds, the costs are to be set off against one another. Section 96 applies as appropriate.

\section{Section 93d.}

[Costs in actions for support of illegitimate children].

(1) In proceedings concerning claims of an illegitimate child against his father for support, the fact that a petition of the father to extend payments or to 


\section{GERMANY}

waive past due support payments is granted does not constitute sufficient ground for imposing a part of the costs on the father's opponents. If the father requests a decision in accordance with $\S 642 \mathrm{f}$, he has to bear the costs of the proceedings.

(2) The court may impose all or part of the costs on the father's opponent if for special reasons that is equitable.

\section{Section 94.}

[Costs of transferred claims]

If the plaintiff pursues a claim acquired by transfer without having first, before commencing the action, given the defendant notice, and, if requested, proof of the transfer, he is liable for the litigation costs to the extent that they result from the fact that failure to give notice or proof have caused the defendant to contest the claim.

\section{Section 95.}

[Costs in case of default or fault]

The party that misses a hearing date or a deadline or that negligently causes postponement of a hearing date, adjournment of a trial, setting of a new date for continuation of the trial, or extension of a deadline has to bear the costs caused thereby.

\section{Section 96.}

[Costs of unsuccessful means of offense or defense]

The costs of an unsuccessful means of offense or defense may be imposed on the party relying on it even if that party prevails on the principal issue.

\section{Section 97.}

[Costs of appeals]

(1) The costs of an unsuccessful appeal are imposed on the party that filed the appeal.

(2) The costs of the appeal proceedings are to be imposed in whole or in part on the prevailing party if it prevails on the basis of new facts that could have been presented in a lower court.

(3) Paragraphs 1 and 2 apply as appropriate in family matters of the kind specified in $\S 621(1)$ nos. 1-3, 6, 9 that are consequential issues of a divorce case.

\section{Section 98.}

\section{[Settlement costs]}

The costs of a settlement are deemed to be set off against one another unless the parties have agreed otherwise. The same applies with respect to the costs of the litigation resolved by the settlement to the extent that no final decision has been made on them. 
GERMANY

Section 99.

[Appeal of cost decisions]

(1) The decision on the costs is not subject to appeal except where an appeal is filed against the decision on the principal issue.

(2) If the principal issue is resolved by judgment based on acknowledgement, the decision on the costs is subject to immediate appeal. Prior to the decision on the appeal, the opponent is to be heard.

\section{Section 103.}

[Determination of costs; principle; petition]

(1) The claim for reimbursement of litigation costs can only be enforced on the basis of an execution order.

(2) The petition to determine the reimbursable amount is to be filed with the office of the trial court. It may be accompanied by the statement of the costs, a copy thereof for the opponent, and the documents supporting the individual cost items.

\section{ITALY*}

Code of Civil Procedure of October 28, 1940.

First Book: General Provisions

Title III: Parties and Attorneys

Chapter IV: Parties' Liability for Litigation Costs and Damages

\section{Article 90 (Cost burden).}

Except as provided otherwise by the provisions concerning legal aid, each party in the course of litigation must provide for the costs of the acts performed and requested, and must advance them if that is required by statute or by the judge.

\section{Article 91 (Order to bear costs).}

In the judgment concluding the proceeding before him, the judge shall order the defeated party to reimburse the other party for the costs, and shall also assess the amount of the costs, as well as that of the honorarium of the attorneys. The same order shall be made by the judge who decides whether the court has jurisdiction.

The costs of the judgment are specified by the court clerk in a note on the margin of the judgment; the costs of notification of the judgment, of issuing an

* Source: I Quattro Codici (1980). Translated by Werner Pfennigstorf. 


\section{ITALY}

extension order, and of the summons are specified by the office of the court by note on the margin of the original and the copy notified.

Article 92 (Order to bear costs for individual acts; compensation).

In announcing the order referred to in the preceding article, the judge may exclude reimbursement of costs incurred by the prevailing party if he considers them excessive or superfluous, and he may, irrespective of the outcome, order one party to reimburse those costs, including those that generally are unreimbursable, that it has caused to the other party by violating the duty referred to in art. 88 .

If both parties are defeated reciprocally, or if other equitable grounds are present, the judge may set off all or part of the costs among the parties.

If the parties have settled the case, the costs are deemed to be set off except if the parties have provided otherwise in the written settlement.

\section{Article 93 (Subtraction of costs).}

The authorized attorney may request that the judge, in the judgment by which he orders payment of the costs, subtract in his and the other attorneys' favor the unpaid honorarium and any costs that he has advanced.

Article 94 (Costs to be paid by representatives or curators).

Privileged heirs, guardians, curators, and in general all those who represent or assist the party in court may, on serious grounds, which the judge must specify in the judgment, be ordered to pay personally the costs of the entire litigation or of individual costs, either alone or jointly and severally with the party they represented or assisted.

\section{Article 96 (Aggravated liability).}

If it appears that the defeated party has acted or resisted in court in bad faith or gross fault, the judge may, on the request of the other party, order the defeated party, to pay, in addition to the costs, damages to be specified, at the court's own motion, in the judgment. 


\section{Netherlands*}

\section{Code of Civil Procedure of September 16, 1896.}

First Book: Procedure before the canton courts, the arrondissement courts, the courts of appeals, and the Supreme Court

First Title: General provisions

Fourth Division: Judgments in general

\section{Article 56.}

(1) Anyone who is defeated by judgment shall have the costs imposed on him. However, all or part of the costs may be apportioned among spouses, persons related by blood in direct line, brothers and sisters, or persons related by marriage in the same degree, and also if both parties are mutually defeated on some points. Also, the judge may leave the costs that were unnecessarily incurred or caused at the charge of the party that had incurred or caused them.

(2) In provisional, preparatory, or interlocutory judgments, the decision on the costs may be reserved for the final judgment.

(3) The amount of the costs imposed on the defeated party shall be specified by the judgment, insofar as these costs have been incurred prior to the decision and not as a consequence of it.

(4) In matters where the law requires or permits acts to be performed by advocates or procureurs, statements of the costs are to be submitted to the judge by the procureur or, in appeals to the Supreme Court, by the advocate immediately after the presentation or pleading of the case or after submission of the petition by the state's attorney. If this is not done, the amount of the costs shall be assessed exclusively according to the judge's estimate.

\section{Article 57}

(1) In the matters referred to in the next to the last clause of the last preceding article, the judgment may impose on the defeated party no other costs of the opposing party than the remuneration and expenses of the procureur of the opposing party, if no one but a procureur had acted for it.

(2) If the matter has also been handled by an advocate, his remuneration shall be included in the costs specified in the first paragraph, provided that in no case greater costs may be imposed on the defeated party on account of the handling of the case by an advocate than if only a procureur had been employed to handle the case.

(3) With respect to appeals before the Supreme Court, the costs to be imposed on the defeated party comprise the remuneration and expenses of one

* Source: De Nederlandse Wetboeken (J. Fruin ed. 1982). Translated by Werner Pfennigstorf. The author gratefully acknowledges the assistance of Dr. Willem Brakel in translating this text. 


\section{NetherlandS}

advocate instead of the remuneration and expenses of the procureur, leaving unaffected the provision of the second paragraph of art. 418 .

(4) For the rest, each party bears its own costs.

(5) The remunerations shall be assessed in accordance with schedules established by law.

\section{Article 57a.}

(1) In cases tried before the canton judge, the costs to be imposed on the defeated party also include an amount to be assessed by the canton judge for necessary travel and lodging expenses of the opposing party.

(2) If the case has been handled by or with the assistance of a representative, the costs include an amount to be assessed by the canton judge for the remuneration and necessary expenses of the representative, unless the canton judge, for reasons to be expressed in the judgment, decides otherwise.

\section{Article 58.}

Advocates, procureurs, and bailiffs who in providing their services exceed their authority, and all who neglect the interests whose administration is entrusted to them may be ordered to pay personally and from their own funds, all or part of the costs, and even to pay damages if there are reasons therefor, without being able to recover them from their principals.

\section{NORWAY*}

Law on Judicial Procedure in Civil Cases of August 13, 1915.

First Part: General provisions

Chapter XIII: Processual costs

\section{Section 169.}

The costs which according to law are involved in a processual act shall be paid by the party requesting the act, or in whose interest the court decides to perform it. If a processual act is performed at the request of both parties, or according to decision of the court in the interest of both, they are liable jointly and separately.

The King may decide to what extent expenses for use of court interpreters shall be born [sic] by the Treasury.

\section{Section 170.}

The costs mentioned in $\S 169$ shall be paid by the parties before the processual act is performed, unless otherwise provided by statute. If the costs cannot be cal-

* Source: Norwegian Laws (1980). Official translation. 


\section{NORWAY}

culated in advance, the parties shall deposit with the court a sum which according to the court's estimate will be sufficient.

If an insufficient advance payment has been deposited at the time when the declaration of a processual act is presented, the court shall stipulate a short timelimit for the payment. If the payment is not made before the expiry of said timelimit, the declaration shall be considered as not having been received, unless the rules of the third paragraph of this section are applicable. If payment is made before the expiry of the time-limit, the fact that it is made after the presentation of the declaration shall not affect the decision in the question as to when such presentation took place.

If the court deems that the party having requested a processual act is unable to make immediate payment, and that he would suffer loss or major inconvenience if he is unable to have the processual act performed, the court can nevertheless allow it to be performed. If a respite has been granted under $\S 4$, second paragraph, of the State Fees Act, or if such respite can be expected, the court shall allow the performance of the processual act. If said processual act necessitates disbursements, the money can temporarily be defrayed by the Treasury.

When a processual act as mentioned in the preceding paragraph has been performed, the court shall stipulate a time-limit for the payment. Until payment has been made or the time-limit has expired, the court shall only perform such steps in the case as it deems necessary. If payment is not made before the expiry of the time-limit, the case shall be rejected.

If a party who has requested a processual act fails to pay for such transactions as necessarily accompany the request, the case shall be rejected unless a respite is granted.

The public claim under this section can be collected by distraint according to the court's statement.

\section{Section 171 .}

When a processual act has been performed at the request of both parties or according to decision of the court in the interest of both parties, the costs which according to law are connected therewith shall finally rest on each of the parties in an equal amount, unless it is enjoined on the one party to pay the costs of the case to the opposing party.

\section{Section 172.}

If the one party loses the case entirely, he shall be ordered to pay the opposing party his processual costs.

An exception shall be made, however, if the case was so doubtful that there was satisfactory ground for the losing party to allow it to come before the court, or the circumstances on which the result rested have without his fault become known to him only during the main hearing, or if blame can be placed wholly or partially on the winning party for the fact that the dispute has resulted in a court action. 


\section{NORWAY}

Section 173.

If a suit is instituted without the defendant by his conduct having given reasonable ground for it, and he without unnecessary delay accepts the claim and offers the performance which is demanded, it shall be enjoined on the plaintiff to defray his processual costs.

Section 174.

When a suit is partially won and partially lost, each of the parties shall bear his costs.

The court can, however, enjoin on one of the parties to indemnify the other a portion of his processual costs or even enjoin on him to pay the costs of the case as a whole. This holds good in particular when it is only in points of dispute of little significance he has won the case, or when he has not won more than he would have obtained by accepting an offer of compromise, which the other party has put forward, or when it appears from the circumstances that the court action or the chief part of the costs have been caused by the points of dispute in which he has lost.

\section{Section 175.}

If the suit is dismissed, or if it ends in other respects without a judgment, the plaintiff shall be ordered to pay the defendant's cost, unless the outcome is due to circumstances for which he cannot be blamed, or the court on account of the doubtfulness of the legal question concerned finds ground to absolve him from the duty of indemnification.

If the suit is dismissed because the liability has ceased to exist by subsequent circumstances, the plaintiff can be awarded indemnification for costs from the defendant.

If the suit is settled by a compromise, each of the parties shall bear his costs, unless otherwise provided by the compromise.

To guide the court, a counsel who demands payment of costs by the opponent shall state the total amount he will be charging to the account of his party for the case concerned, and each party shall furnish a statement of the amount he seeks to recover from the opponent, divided into payment for work which he or the counsel has performed on the case, and other costs. It is not necessary to provide statements pursuant to this paragraph in cases decided without oral proceedings.

For the guidance of the court, an attorney who demands processual costs of the opposing party shall give an account of what he charges his party in the respective case, and each party shall submit a statement of what he demands reimbursed of the opposing party, divided into compensation for work that he or his attorney has done on the case, and other costs. Statements complying with this provision need not be submitted in cases that are decided without a hearing.

Section 176 .

When indemnification for costs of the case is to be awarded to a party, the indemnification shall cover all the costs he has had in connection with the case, in 


\section{NORWAY}

so far as, according to the opinion of the court, they were required for a proper handling of the case. If a party has conducted the case against better judgment, he may be ordered to pay all the costs of the opposing party, irrespective of whether they were necessary.

\section{Section 177.}

If one party has by unlawful conduct during the action or by negligence caused the other party expenses, the court may order him to pay these, irrespective of the outcome of the case.

If a party has unduly protracted the action or made it unduly complicated, he can in the same manner be ordered to pay indemnification to the other party for the injury and inconvenience which is presumed to have been caused.

\section{Section 178.}

If there are several parties to a case or, besides the parties, there are also assisting interveners, the rules laid down above shall apply correspondingly.

The court shall apportion the costs when several parties are to defray them, and decide whether they shall be liable jointly and separately. Such liability shall be enjoined when they are liable jointly and separately with respect to the subject matter of the dispute, and can in any case be enjoined with respect to costs which do not exceed what the individual party would have had to defray if there had been no processual associations or assisting intervention.

The costs according to $\S 177$ shall be enjoined only on the party who has caused them.

\section{Section 179.}

The matter of costs shall be decided by the court in the judgment or in the ruling which concludes the case. In this decision the court shall specify the amount awarded for work performed by the party or his counsel, and the amount awarded for the coverage of other costs. If the judgement or ruling applies only to part of the case, and the court finds that it cannot decide the question of costs separately for this part, the decision, may be postponed until the judgement or ruling which concludes the whole case.

Costs shall be awarded only when the party submits a statement of the costs which he is seeking to recover. However, this does not apply in cases decided without oral proceedings. Where the court so desires, it may obtain a statement to be used at the taxing of the litigation costs.

\section{Section 180.}

A person who has appealed or challenged in vain shall be ordered to pay the costs of the proceedings before a superior instance, unless the court on account of 
NORWAY

special circumstances finds that it ought to absolve him from the duty of indemnification.

The rules which are laid down above in this chapter shall apply in a superior instance to all costs which have accrued in the action or in that part of the action which is decided by the superior instance.

\section{Section 181.}

The question of imposing and stipulating processual costs can only be tried by a superior instance if the case itself is brought before it.

But the decision may be challenged on the basis that the question of costs has been decided at variance with law. If the case has been decided by judgment, the superior instance is bound by the lower court's appraisal of the evidence in the case.

The attorney is entitled to have what is due to him for his outlays and work on the case covered out of the costs which are awarded to his party. Such portion of the costs as is necessary for this cannot be impounded by the other creditors of the party, and the attorney may claim to have it paid directly to him.

\section{SPAIN*}

(A) Law of Civil Procedure of February 3, 1881.

First Book: Common provisions for contentious and voluntary proceedings Title I: Appearance before the court

Division 2: Legal aid

\section{Article 31.}

(1) If legal aid is denied, the costs of the first instance shall be imposed on the applicant.

(2) In case of an appeal, those of the second instance shall be imposed on the appropriate party according to law.

Title V: Disqualification

Division 2: Disqualification of judges

Article 211.

If the recusation is denied, the costs shall always be imposed on the party that had requested it.

Division 3: Disqualification of municipal judges

Article 227.

If the order affirms, the costs shall be imposed on the appellant.

* Source: Enjuiciamiento civil (1976). Translated by Werner Pfennigstorf. 
SPAIN

Article 228.

If the recusation is denied, the costs shall be imposed on the party that had requested it, and in addition a fine of 100 pesetas shall be imposed, subject to the provisions of the second paragraph of art. 212 and of art. 213.

Division 4: Disqualification of court officials

Article 245.

(1) If it is decided that recusation shall take place, the costs of the proceeding shall be imposed on the recused official if he had denied the truth or the merits of the alleged ground.

(2) If recusation is denied, the costs shall be imposed on the party that had requested it, in addition to the payment of the emoluments provided for in art. 247.

Title IX: Appeals against judicial decisions and their effects

Division 1: Appeals against decisions of trial judges

Article 396.

If the trial court dismisses the aforementioned claim, the costs of this proceeding shall be imposed on the appellant . . . .

Second Book: Contentious proceedings

Title II: Proceedings for judgment

Chapter III: Cases for small amounts

Article 710.

(4) The judgment that confirms or adds to that of the first instance shall impose the costs on the appellant.

Title VI: Appeals

Division 1: General provisions

Article 842.

(1) In all cases where the appeal is declared abandoned, the appeal costs shall be imposed on the appellant ... .

Title VIII: Execution of judgments

Division 1: Judgments announced by Spanish courts or Judges

Article 950.

(1) The costs caused by measures for execution are at the charge of the party condemned in the judgment for which execution is sought.

Title XXI: Appeals for annulment 
SPAIN

Division 5: Processing and decision of appeals admitted for violation of law or legal theory

\section{Article 1748.}

In the judgments deciding that the appeal is not admissible, the appellant shall be ordered to pay all the costs and to forfeit the deposit . . . .

Division 6: Filing, admission, and processing of appeals for procedural error

Article 1767.

If it is decided that the appeal is not admissible, the appellant shall be ordered to pay all the costs and to forfeit the deposit.

Title XXII: Appeal for revision

Division 4: Judgments announced on appeal for revision

Article 1809.

If the appeal for revision is declared unfounded, the party that pursued the appeal shall be ordered to pay all the costs of the litigation and to forfeit the deposit.

(B) Regulation of November 21, 1952, for the Implementation of the Tenth Principle of the Law of July 19, 1944, Concerning

Procedural Rules applicable to Municipal Courts.

Article 60.

In the decisions that terminate the litigation, there shall be a decision on the payment of costs, which shall be imposed on the party whose claims have been completely rejected. If the claim has been partially approved or denied, each party shall pay the costs caused by it, and the common costs, at one-half.

\section{SWEDEN*}

Code of Judicial Procedure of July 18, 1942.

Part 2: Proceedings in General

I: Proceedings in Civil Cases

Chapter 18: Litigation Costs

\section{Section 1.}

The losing party shall reimburse his adversary for litigation expenses if nothing to the contrary is provided.

* Source: The Swedish Code of Judicial Procedure Rev. Ed. (A. Bruzelius \& K. Thelin trans. 1979). Copyright (C) 1979 by New York University. Reprinted by permission of New York University and 


\section{SWEDEN}

\section{Section 2.}

In an action concerning a matter that by law may not be resolved finally without judicial confirmation, the court may direct that each party shall bear his own expenses.

\section{Section 3 .}

If the winning party is found to have initiated the action without provocation from his adversary, or otherwise to have deliberately or negligently caused unnecessary litigation, he shall reimburse his adversary for the latter's litigation expenses, or, if the circumstances so justify, each party shall bear his own expenses.

If the losing party neither knew nor should have known of the outcome determinative circumstances prior to the commencement of the action, the court may direct that each party shall bear his own expenses.

\section{Section 4 .}

If in a multi-claim action each party is both winner and loser, either each party shall be required to bear his own expenses, or one of the parties shall be awarded an adjusted compensation for his expenses, or, to the extent that the expenses attributable to different parts of the action are severable, the liability to compensate for expenses shall be determined by the outcome of each part. However, if the portion of the case which the party has lost is of only minor importance, he may receive full compensation for his expenses.

If only a part of a party's claim is granted, the preceding paragraph shall correspondingly apply.

\section{Section 5 .}

A party whose claim is dismissed without reaching the merits is deemed the loser.

A party who withdraws his claim or whose claim is written off by reason of his failure to appear shall reimburse the adverse party for his expenses, unless special circumstances indicate that a different resolution is appropriate.

If the parties settle the action by private agreement, in the absence of a contrary provision in the settlement agreement, each party shall bear his own expenses.

\section{Section 6.}

If a party's failure to appear or to comply with a court direction, or presentation of a claim or defense that he knew or should have known to be without merit, or carelessness or oversight in other respects has occasioned adjournment of the proceedings or has otherwise caused expenses for the adverse party, that party

Fred B. Rothman \& Co. The text reproduced here reflects later amendments to $\$ 8(\mathrm{SFS} 1981: 741)$ and $\S 14$ (SFS 1982:1123). 


\section{SWEDEN}

must reimburse the adverse party for such expenses, regardless of how costs in general are to be distributed.

\section{Section 7.}

If, pursuant to this chapter, a party must provide compensation for the adverse party's litigation expenses, in whole or in part, and it is found that the party's legal representative, attorney or assistant has caused the expenses by conduct described in section 3, paragraph 1, or by such carelessness or oversight as is referred in section 6 , the court, even if not requested to do so, may impose joint liability for costs upon the party and his representative, attorney or assistant.

\section{Section 8.}

Compensation for litigation expenses shall fully cover the expenses of preparation and presentation of the action including counsel fees to the extent that the expenses were reasonably incurred for the protection of the party's interest. Compensation shall also be paid for the time and effort expended by the party by reason of the action. Negotiations aimed at settling an issue in dispute which bear directly upon the outcome of a party's claim are deemed measures for the preparation of the action.

Compensation for litigation expenses shall also include interest at six percent from the date of the adjudication of the action until payment is made.

\section{Section 9.}

If compensation for litigation expenses is to be furnished by several parties joined on the same side, such parties are jointly and severally liable for the expenses. However, to the extent that items of expense are chargeable to a portion of the action involving only one of the co-parties, or that one of the co-parties has occasioned items of expense by such carelessness and oversight as is described in section 6, only the co-party who occasioned the expenses shall be charged.

When, pursuant to section 7 , a person is obliged to reimburse litigation expenses together with a party, he and the party are liable for the expenses jointly and severally.

\section{Section 10.}

When party substitution occurs on the plaintiff's side pursuant to chapter 13, section 7, the original plaintiff and his successor are jointly and severally liable for expenses incurred prior to the substitution; after substitution the successor bears sole responsibility.

The successor of an original defendant is solely liable for the litigation expenses. 


\section{SWEDEN}

\section{Section 11 .}

When two or more persons are jointly and severally liable for litigation costs, on request of one of them, the court, based upon the particular circumstances, may specify the portion of the expenses that each should ultimately bear, or authorize complete indemnification of one or more by the other.

\section{Section 12}

As to the liability of an intervenor who lacks party standing to furnish compensation for litigation expenses, and the right of such an intervenor to be compensated for his expenses, the provisions in this chapter concerning parties shall correspondingly apply; however, the intervenor shall be solely liable for the special expenses occasioned by his intervention. Nor may the party supported by the intervenor be directed to furnish compensation for such expenses.

\section{Section 13}

As to disbursements for evidence or for any other measure which in the course of the action the court has ordered to be paid out of public funds, or has charged to the parties jointly and severally, the provisions in this chapter concerning the liability to provide reimbursement for litigation expenses shall apply. If each party shall bear his own expenses, such disbursements may be apportioned equally between the parties. Expenses out of public funds for bringing a party to court in custody shall always be charged to that party.

Concerning liability to compensate the Crown for expenses on behalf of a party granted public legal aid, special provisions have been enacted.

\section{Section 14}

A party desiring to be reimbursed for litigation expenses shall make a demand for, and make a statement of, his expenses to the court before the termination of the proceedings. If he fails to do this, he forfeits his right to be reimbursed for expenses incurred in that court; however, despite the absence of a demand, the winning party is entitled to interest referred to in section 8 , paragraph 2 , and to a copy of the judgment or final order at his adversary's expense.

When finally disposing of an action, the court shall simultaneously rule upon the litigation costs and upon the issues mentioned in section 13, paragraph 1. If counsel fees are to be reimbursed, the amount of the fees shall be separately stated.

\section{Section 15}

The determination concerning liability to provide compensation for litigation costs incurred in an appellate court in an appeal from a court below shall be based upon the outcome of the action in that court.

As to liability for expenses incurred in a higher court when the proceeding 


\section{SWEDEN}

concerns an issue separately appealed to that court, the provisions in this chapter as to actions instituted in lower courts shall correspondingly apply.

If an action is referred back to a court below, the issue of expenses incurred in the higher court shall be determined by the court below when it rehears the case.

\section{ZURICH* \\ Code of Civil Procedure of June 13, 1976}

I Part: General Provisions

Division 4: Litigation Costs

A: Court Costs and Reimbursement of Litigation Expenses

\section{Section 64 .}

The amount of the court costs is determined as provided by the Act on Court Organization.

They are as a rule imposed on the defeated party. If neither party prevails fully, the costs are apportioned proportionally.

The court may deviate from this rule especially if the defeated party believed in good faith to have a ground for litigation or if the plaintiff could not reasonably be expected to specify the precise amount of his claim and his complaint was sustained in principle.

\section{Section 65 .}

If the case is rendered moot or if the plaintiff ceases to have a lawful interest in the action, the court decides on the costs according to its discretion.

In the case of a settlement the costs are, as a rule, imposed one-half on each of the parties, unless the parties have agreed otherwise. Such agreements are not binding for the court if they have an adverse financial effect on the court.

\section{Section 66.}

If a party has caused costs unnecessarily, such costs are imposed on the party irrespective of the outcome of the litigation.

Costs that have not been caused by either party are as a rule assumed by the court.

Costs may be imposed on witnesses or other third persons to the extent that they have negligently caused such costs.

\section{Section 68.}

As a rule, a party must reimburse the opposing party for out-of-court costs and

* Source: Zürcher Gesetzsamnlung, Band 46 (1976-78). Translated by Werner Pfennigstorf. 


\section{ZURICH}

expenses, including costs of advice, in the same proportion as it has costs imposed on it. This applies as appropriate to third persons on whom costs are imposed according to $\S 66(3)$.

In the case of a settlement, no reimbursement of costs is ordered unless the parties have agreed otherwise.

\section{Section 69.}

The reimbursement is assessed at the discretion of the court. The parties may prior to the decision submit their statements to the court. 